\title{
ENTRE VOZES VIAJANTES: exploração vocal no Teatro Invisível de Meredith Monk.
}

Versão corrigida (Versão original disponível na Biblioteca da ECA/USP)

Inés Terra Brandes

São Paulo - 2019 
O presente trabalho foi realizado com apoio da Coordenaçáo de Aperfeiçoamento

de Pessoal de Nível Superior - Brasil (CAPES) - Código de Financiamento 001.

\section{Universidade de São Paulo}

Inés Terra Brandes

ENTRE VOZES VIAJANTES: exploração vocal no Teatro Invisível de Meredith Monk.

Dissertaçáo apresentada ao Programa de Pós-graduaçáo em Música, Área de Concentração Processos de Criação Musical, Linha de Pesquisa Sonologia: criação e produção sonora, da Escola de Comunicaçóes e Artes da Universidade de São Paulo, como exigência parcial para obtenção do título de Mestre em Música, sob orientação do Prof. Dr. Rogério Luiz Moraes Costa.

$\begin{array}{lr}\text { Banca Examinadora } & \\ \text { Prof. Dr._Instituição: } & \text { Assinatura } \\ \text { Julgamento: _Instituição: } \\ \text { Prof. Dr. Assinatura } \\ \text { Julgamento: } \\ \text { Prof. Dr. Instituição: } \\ \text { Julgamento: Assinatura }\end{array}$




\section{AGRADECIMENTOS}

Ao Garrison Institute por ter me concedido à bolsa para participar do retiro Voice as Practice com Meredith Monk.

À Meredith Monk, por ter autorizado a digitalização de documentos da Biblioteca Pública de Nova York, pelo retiro em Garrison e por tudo aquilo que me fez fazer esse trabalho.

À Lanny Harrison e Deborah Kavash, pela disponibilidade e confiança.

À Phil Minton, à Lilian Campesato, Flora Holderbaum, Lea Taragona, Wânia Storolli, Ligia Liberatori, Barbara Togander, Ute Wassermann, por terem respondido os meus formulários.

Ao meu orientador Rogério Luiz Moraes Costa, por ter confiado na minha proposta de pesquisa desde o início e ter respondido com tanta tranquilidade os meus constantes questionamentos.

À banca de qualificação: Janete El Haouli e Lilian Campesato, por terem lido o meu trabalho com tanto envolvimento e por terem apontado possibilidades para a pesquisa. À Pedro Campanha, amigo e parceiro nesse trabalho, por se dispor a diagramar a dissertação.

À Beatriz Sano, pela colaboração e por me incentivar a continuar e transformar.

À Julia Teles, pela cumplicidade e amizade, e pelas inúmeras parcerias do passado, presente e futuro.

Catalogação na Publicação

Escola de Comunicações e Artes da Universidade de São Paulo Dados inseridos pelo(a) autor(a)

Brandes, Inés Terra
ENTRE VOZES VIAJT

ENRTE

Luiz Moraes Costa. Inés Terra Brandes

p.: il. + CD.

Dissertação (Mestrado) - Programa de Pós-Graduação em Música
- Escola de Comunicações e Artes / Universidade de são Paulo. Bibliografia

1. Meredith Monk 2. Key (1971) 3. Exploração Vocal 4.
Composição Vocal I. Moraes Costa, Rogério Luiz II. Título.

CDD 21.ed. - 780

Elaborado por Sarah Lorenzon Ferreira - CRB-8/688

À Lea Taragona, pela profunda amizade, agora antiga, suas vozes, e especialmente pela escrivaninha "histórica" que me acompanhou nesse processo de escrita.

À Asiya Wadud, Vanessa Grecco, Bernardo Barros, por me receberam em Nova York e pela amizade.

À Enric Llagostera, Agnes Hvizdalek, Raíza Sanctis, Daiana Carvalho e Olguinha, Tetembua Dandara, Greg Slivar, Lucas Ogasawara, Meghie Rodrigues, Adriana Amaral, Cadós Sanchez, Rubinha, Nina Giovelli, Larissa Ballarotti, Daniela Alves, Amaral, Cadós Sanchez, Rubinha, Nina Giovelli, Larissa Ballarotti, Daniela Alves,
Sol Martincic, Henrique Cartaxo, Isabel Nogueira, Maíra Martinez, Regiane Ishi, Sol Martincic, Henrique Cartaxo, Isabel Nogueira, Maíra Martinez, Regiane Ishi,
Gustavo Lemos, Valéria Bonafé, pela amizade e parceria. Âs amigas de pesquisa, sons e caftés, Flora Holderbaum, Clarissa Moser, Alexandre Nakahara, Renata Oliveira e Stenio Biazon. Às parceiras de som e amigas: Nahnati Francischini, Mariana Carvalho, Marina Mapurunga, e Bella.

Ao projeto DISSONANTES, organizado por Natacha Maurer e Renata Roman. À residência Campo Comum da companhia Keyzetta e cia. À CASA LÍQUIDA e à Julia Feldens, por me acolher e pela troca. Ao LEVIATÁ, por receber a série LÍNGUA FORA. À ORQUESTRA ERRANTE, pelos sons compartilhados.

Às minhas alunas e alunos, porque tudo o que eu faço se encontra atravessado pela potência desses encontros.

À Solange Tola, pelo apoio constante e a confiança.

Aos meus pais, à Gloria, Lucas, e aos meus sobrinhos Rafi e León.

À Caetano Tola, por existir e pelas incontáveis conversas que me fizeram dizer em voz alta aquilo que não conseguia colocar em palavras. 


\section{CONSIDERAÇÕES INICIAIS}

Todas as transcriçóes e traduçôes do inglês e do espanhol para o português foram realizadas por mim especialmente para esse trabalho, quando não for descriminado no texto.

A diagramação desse trabalho foi realizada pelo artista Pedro Campanha e pretende facilitar a leitura, propondo uma distinçáo entre as palavras de Meredith Monk, as referências de outras autoras e as experiências e reflexōes pessoais. 


\section{RESUMO}

BRANDES, I.T. ENTRE VOZES VIAJANTES: exploraçáo vocal no Teatro Invisível de Meredith Monk. 2019. Dissertação (Mestrado) - Instituto de Música. Universidade de São Paulo, São Paulo, 2019

As Notas sobre a Voz são enunciados que a artista Meredith Monk (Estados Unidos, 1942) escreve durante os primeiros anos de carreira sobre procedimentos presentes nas suas composiçôes vocais e sobre o seu entendimento de voz até entáo (1976). As Notas apresentam uma cronologia de descobertas da artista, e ao evidenciar o cruzamento entre diferentes áreas de conhecimento (artes performáticas, psicologia, linguística, filosofia), possibilitam desdobramentos bibliográficos para uma reflexão entre a prática inicial da artista e outros trabalhos composicionais a partir da exploraçáo de vozes. Entendendo a Notas como uma declaraçáo indicadora de questóes fundamentais, no que se refere aos processos de criação a partir da potência vocal, investigo os modos de exploraçáo voca presentes nas composiçóes do disco Key (1971), e crio diálogos entre a poética de Monk e a minha experiência como performer vocal. Esses diálogos são possíveis pela relevância artística das Notas de Monk, e pela ênfase nas transformaçôes que as vozes apresentam durante a sua exploração, entendendo a mesma como um processo composicional. Em Key, Monk cria um ambiente em constante mudança que ela chama de "Teatro invisível". Nas palavras da compositora: "Cada cançäo apresenta uma personagem vocal, uma paisagem, uma preocupação técnica e uma qualidade emocional diferente." Como parte do diálogo com as propostas de Monk, no terceiro capítulo são apresentadas duas peças da minha autoria.

Palavras chave: Meredith Monk, Notas Sobre a Voz, Vozes Viajantes, Teatro Invisível, Key (1971).
ABSTRACT

Notes on the Voice it's an artistic statement that Meredith Monk (United States, 1942) wrote during the first years of her career on procedures present in her vocal compositions and on her understanding of voice until then (1976). The Notes present a chronology of the discoveries of the artist, and by highlighting the intersection between different areas of knowledge (performing arts, psychology, linguistics, philosophy), allow bibliographical unfoldings for a reflection between the artist's initial practice and other compositional works from the exploration of voices. Understanding the Notes as an artist statement of fundamental questions, regarding the creation processes from the vocal possibilities, I investigate the modes of vocal exploration present in the compositions of the album Key (1971), and I create dialogues between the poetics of Monk and my experience as a vocal performer. These dialogues are possible by the artistic relevance in Monk's Notes, and by emphasizing the transformations that the voices present during their exploration, understanding it as a compositional process. In Key, Monk creates an ever-changing environment called as "Invisible Theater." In the words of the composer: "Each song presents a vocal character, a landscape, a technical concern and a different emotional quality." As part of the dialogue with Monk's proposals, two pieces of my own are presented in the third chapter.

Key words: Meredith Monk, Notes on the Voice, Travelling Voices, Invisible Theater, Key (1971). 
Introdução

Trajetória pessoal e motivações $-17$

As Notas sobre a Voz $-23$

Escolha de Key (1971) — 28

Entre vozes viajantes -29

Sobre as vozes $\longrightarrow 33$

Percurso do trabalho

$-34$

\section{Capítulo I: Meredith Monk}

Apresentação

Key (1971)

Teatro Invisível, Espacialidade e Continuidade $\longrightarrow 52$

Procedimentos para a exploração vocal

Categorias para as análises das vozes

$-59$

Capítulo II: As Notas sobre a voz (1976)

e Key (1971)

A voz como ferramenta para descobrir, ativar,

lembrar, desvelar, demonstrar uma consciência pré-lógica/primordial: Porch (faixa um, 2:14)

Trabalhando com um companheiro: What does it mean? (faixa três, 3:58) 
A voz como linha direta para as emoções. Todo o

A emoção.Sentimentos para os quais

não temos palavras: Fat Stream (faixa cinco, 7:28) $\longrightarrow 77$

A voz como linguagem: Visões, Vision \#2

(faixa seis, 2:03)

A voz como manifestação do Self, Persona ou

Personas: Do You Be (faixa sete, 4:12)

Paisagem Vocal: Change (faixa nove, 3:45)

86

A voz que dança. A voz tão flexível quanto a

coluna: Dungeon (faixa dez, 6:49)

\section{Capítulo III: A voz como prática}

Retiro Voice as Practice - com Meredith Monk e

Ellen Fisher

Peça I: Solo para voz desacompanhada - Una

mirada desde la alcantarilla $\longrightarrow 102$

A voz do corpo/o corpo da voz

Peça II: Paisagem Vocal - Rastros —126

Exploração Vocal — 129

Técnicas Estendidas da Voz 132

Considerações Finais 
explicar con palabras de este mundo que partió de mi un barco llevándome.

(Alejandra Pizarnik) 


\section{INTRODUÇÃO}

\section{Trajetória pessoal e motivações}

Em 2010 subi em um ônibus na Estaçáo de Retiro em Buenos Aires (a minha cidade natal) e em trinta e oito horas cheguei à rodoviária do Tietê, em São Paulo. Levava cem quilos de bagagem, mais um teclado e um violão. Após mais uma hora e meia de viagem cheguei em Campinas, onde fui recebida pelo pianista de Cosmópolis (SP) Felipe Siles, quem achou um lugar para eu morar no meu primeiro ano em Barão Geraldo.

Estudei voz popular na Unicamp e, após o final do curso, fui morar na cidade de São Paulo. "Um fio na garganta" foi o título do meu concerto de fim de curso, orientado pela Profa. Dra. Regina Machado. Extrai o título de uma poesia da escritora Hilda Hilst. Na poesia, Hilst se refere a um fio de cabelo na garganta. A minha escolha foi guiada por essa imagem, e pelo fato de entender que até então esse fio era o que me movia de um lugar a outro, através de cançóes (em sua maioria latino americanas) apresentadas no último concerto de graduação no auditório do Instituto de Artes da Unicamp.

Naquela época, as canções eram tentativas de fazer esse fio sair, puxá-lo do fundo da garganta, inventar o eu que nasce em outro país, na idealização dos obstáculos terem um lugar físico, na vontade de mais autonomia, mais embate e transformação.

Em São Paulo trabalhei no Programa Vocacional (programa de políticas públicas em artes) da Secretaria de Cultura durante três anos. Essa experiência me fez voltar à cidade grande, percebendo as semelhanças com a Argentina (especialmente com Buenos Aires) enquanto país latino - americano e as caraterísticas específicas enquanto sociedade brasileira e paulistana. Orientei grupos e turmas na Casa de Cultura da Brasilândia, em seguida no Tendal da Lapa e no Céu Caminho do Mar. Essas experiências mantiveram a minha vontade de conhecer mais a cidade de Sáo Paulo, reconhecendo suas bordas e muros, conhecendo artistas, músicas e interesses que pouco circulam pela academia, trabalhando com equipes constituídas por artistas de diferentes áreas. Esses encontros, com artistas vocacionadas, articuladoras culturais e artistas da dança, do teatro e da performance, me instigaram a pensar a minha prática como musicista em uma abordagem expandida, e ao mesmo tempo mais crítica em relação ao contexto onde esta é desenvolvida.

Nos meus últimos anos de graduaçáo, as práticas corporais foram uma preo- 
cupação, tanto no meu currículo escolar, quanto na minha pesquisa artística. Entendi que precisava olhar para esse eu/corpo, que continuava o mesmo, embora com uma nova perspectiva. Respondendo a esse desejo fui timidamente me aproximando da dança. Olhar para o corpo significava enfrentar algumas dores, automatismos, e assumir algumas violências. Ao mesmo tempo significava perceber a localização desse corpo como estrangeiro e as suas relaçôes com esse novo contexto.

Na minha chegada a São Paulo entrei em contato com vários equipamentos públicos com programas de aulas de dança gratuitas e consegui criar uma formação continuada com diferentes artistas da dança contemporânea, com diferentes abordagens, todas elas focadas na investigação de movimento a partir da improvisaçấo, porém auxiliadas por outras práticas corporais. Ao longo desses anos me familiarizei com algumas práticas como Tai Chi Chuan, Chi Kung, Seitai - Ho, Ashtanga Ioga, BMM (Body Mind Movement) e Técnica de Alexander, prática que conheci através da cantora Izabel Padovani no Festival de Música de Curitiba em 2008, a primeira vez que estive no Brasil. Pesquisei movimento com as artistas Key Sawao, Beatriz Sano, Andreia Yonashiro, Nina Giovelli, Olivia Niculitcheff, Eduardo Fukushima, Ivo Dimchev e Meredith Monk.

Uma das minhas professoras de voz em Buenos Aires foi a cantora e fonoaudióloga Elisa Viladesau com formaçáo em Educaçáo Funcional da voz pelo método Rabine Institut (Alemanha). Esse método utiliza a técnica somática Feldenkrais como base para atingir uma liberdade vocal sem esforços. Essas experiências começaram a influenciar e a deslocar a minha prática como cantora, aprofundando nas possibilidades do corpo e abrindo o leque do meu repertório vocal.

A expansão desse leque significa entender a potência do corpo vocal para além do que se entende como canto erudito ou popular, para além das línguas, antecipando seus fonemas e vocemas, e aproveitando os resíduos da fala. "O vocema é mais da ordem do grito e do verbo. No começo era o grito; as parteiras sempre souberam disso, mas é bom lembrar os poetas." (ZUMTHOR, 2005). Cada corpo vocal emite inúmeras possibilidades de sons. Na sua tese "Possível Cartografia para um corpo vocal queer em performance" (2015), Jacobs utiliza o termo corpo vocal para se referir "à integridade psicofísica entre corpo e voz" (CAVARERO) $e$ “à presença de uma voz corporificada na realizaçáo de uma obra artística" (ZUMTHOR)

O vocema é um possível vocal. A lista de vocemas seria infinita, estamos definitivamente fora da fonologia clássica dos linguistas, para além das delimilogia clássica dos linguistas, para além das delimitaçóes próprias das línguas naturais. (ZUMTHOR 2007: p. 162)

Ao mesmo tempo confirmei que a voz, como início do processo de criação, possui uma potência para a composiçáo, independentemente das palavras e dos instrumentos que podem acompanhá-la. Entendi que a voz pode ser um instrumento que expande o conceito de composição, ao transitar por várias linguagens e contextos, ao envolver um conhecimento (consciente ou não) aguçado do corpo, e ao estar intimamente relacionada com a biografia pessoal de quem a emite. Para compor com a voz precisamos investigá-la, permitir que ela desenhe no espaço interno e externo do corpo um dizer, muitas vezes caótico e dolorido.

A investigação de "outras vocalidades" já estava presente nas minhas práticas durante o trabalho com o pianista e violinista Demian Luaces em Buenos Aires, Argentina. Foi quando comecei a trabalhar com música. Nessa experiência (de 2004 a 2007) compúnhamos, arranjávamos e repensávamos continuamente a relação entre um piano e uma voz, sempre com a provocaçáo e orientação do professor e pianista Marcelo Katz, grande influência na minha formaçáo musical.

Em seguida, no curso de composição do compositor e professor Ricardo Capellano no Conservatório Manuel de Falla, em Buenos Aires, comecei a compor a partir das possibilidades da voz. O curso promovia encontros entre diferentes instrumentistas no intuito de compor a partir de uma prática semanal de improvisação guiada por diretrizes criadas por Capellano, e de práticas de escuta de composiçôes de diferentes autoras. Paralelamente a esses encontros, era realizado um encontro mensal com o professor para acompanhar os processos composicionais individuais, assim como os questionamentos e as vontades geradas no processo coletivo. Em uma das experiências de escuta me foi apresentado o trabalho da artista Meredith Monk. Até então conhecia outros trabalhos de cantoras contemporâneas que valorizavam sonoridades vocais para além da linguagem e que incluíam o entendido como ruído e vocalidades polifônicas nas suas práticas, mas o trabalho de Monk me chamava a atenção por algum outro motivo que ainda não conseguia decifrar.

Comecei a pesquisar e escutar as suas peças, tanto as que eram exclusivamente musicais, como também as peças teatrais com o seu grupo, os site-specifics, as danças pela cidade de Nova York, e os vídeos. O fato de a artista iniciar as suas criaçōes em ideias vocais me interessou imediatamente.

Apesar de Monk ser norte-americana e eu nunca ter viajado para os Estados Unidos até então, aquelas vozes tinham familiaridade com vozes que tinha escutado no canto andino do norte argentino, algumas vozes remetiam à cidade grande e caótica, outras às liturgias religiosas ocidentais, como o canto gregoriano ou o canto da compositora alemã do século XII Hildegard Von Bingen. Aquelas vozes reuniam muitas histórias (mesmo sem envolver palavras) ampliando o imaginário a cada escuta por meio de sensaçóes criadas a partir do som. Náo se tratava de um repertório incansável 
de novas sonoridades, mas de uma articulaçáo muito pessoal entre qualidade vocal e qualidade emocional, contendo uma narrativa com várias interpretaçóes possíveis.

O retiro que realizei com Monk em 2017 confirmou essa teoria. Durante o curso, Monk trabalhou mais na integração das vozes presentes do que na expansão do repertório vocal ou na experimentação, ensinando diferentes cânones compostos pela artista, e exercícios vocais, alguns provenientes do Somatic Voice Work, método criado pela professora norte-americana Jeannette Lo Vetri.

No meu primeiro ano em São Paulo (2014) cursei como aluna especial a disciplina "Performance e Corpo: Movimento, Respiração e Voz nos processos de criação". Ainda não pensava em fazer mestrado, mas tinha a intenção de voltar a explorar aqueles aspectos da potência vocal que tinha deixado um pouco de lado na minha graduação em música popular com foco na canção.

Além da proximidade com bibliografias vinculadas ao meu projeto, como textos de Antonin Artaud, Adriana Cavarero e Paul Zumthor, conheci de perto a pesquisa da Profa. Dra. Wânia Storolli, e experimentei nas suas aulas a prática da Respiração Vivenciada de Ilse Middendorf como suporte para o canto, prática desenvolvida por ela durante o doutorado. Logo, também participei do grupo LIVE (Laboratório de Improvisação de Vozes Experimentais) durante um ano, organizado pela mesma professora. Participei também dos Seminários de Vozes Performáticas organizados por Storolli.

Ao mesmo tempo comecei as trocas de pesquisa em mobilidade e sonoridade com a artista Marina Matheus, com quem realizei uma residência no Centro de Referência da Dança de 2016 a 2017, criando o projeto Corvo. No marco dessa residência realizamos oficinas, ensaios abertos e uma intervenção no corredor do CRDSP junto com as artistas Daiana Carvalho, Tetembua Dandara, Renata Oliveira, Maria Basulto, Graciela Soares, Beatriz França e Olivia Nicolutcheff.

Paralelamente às práticas corporais, desde que eu moro em São Paulo faço acupuntura. É também a partir dessa vivência como paciente que entendo alguns mistérios do meu corpo e suas vozes, estabelecendo relaçōes entre os órgãos e os estados emocionais, entre um ponto e outro no próprio corpo; confirmando que emoção e fisicalidade são indivisíveis. A história das manifestaçóes do meu corpo revela as formas que a minha voz toma ao longo do meu percurso artístico.

Em 2016 comecei a participar da Orquestra Errante criada pelo Prof. Dr. Rogério Costa. Foi um espaço importante de reaproximação com a universidade, e também de experimentaçáo da pesquisa que estava realizando individualmente. Ao conhecer outras musicistas e pesquisadoras interessadas na experimentação, na improvisação e na composição contemporânea, me senti incentivada a escrever o meu projeto.
Uma abordagem feminista?

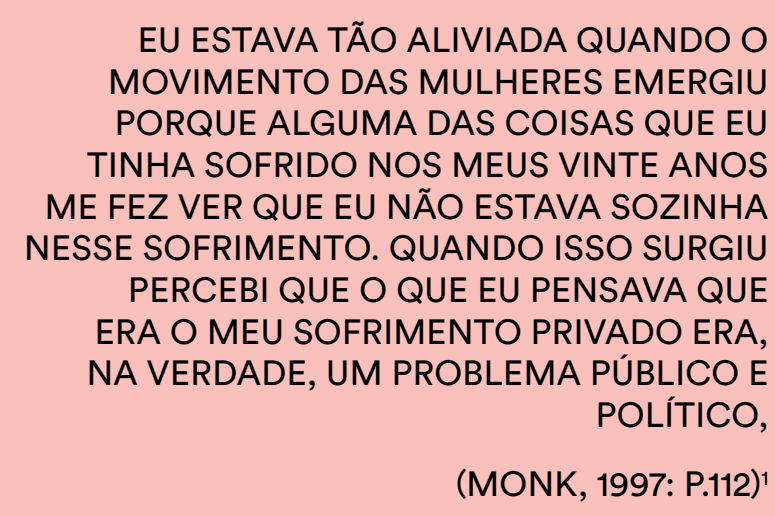

Perceber que as opressōes individuais são consequência de legados estruturais/ institucionais é o primeiro passo para entender o nosso local social e a nossa realidade em relação.

$$
\begin{aligned}
& \text { Se possuo alguma agência é a que deriva do fato de } \\
& \text { que sou constituída por um mundo social que não } \\
& \text { escolhi. Que a minha agência esteja cheia de parado- } \\
& \text { xos não significa que seja possível. Significa unica- } \\
& \text { mente que o paradoxo é a condiçáo da sua possibili- } \\
& \text { dade. (BUTLER, 2006: p. 16) }
\end{aligned}
$$

Ser mulher é uma condiçâo social, estabelecida antes de eu existir no mundo, antes de eu ser capaz de escutar a minha própria voz, antes mesmo de eu ganhar um nome: sou mulher. As definiçóes binárias de sexualidade carregam um peso cujo com-
1 No original: was so relieved when came along because some of the things had suffered from in $\mathrm{my}$ twenties made me see was not alone in that sufering. When that came suffering was my private public, political problem. (MONK in MARRANCA 2014: p.112)

2 No original: $\mathrm{Si}$ tengo alguna agencia es la que deriva del hecho por un mundo socituida no escogí. Que mi agencia esté repleta de paradojas no significa que sea imposible. Significa solo que la paradoja es la condición de su posibilidad.
(BUTLER, 2006: p. 16) in I realized that what bate leva a exaustão, por se tratar de tecnologias político-sociais ligadas ao sistema reprodutivo e produtivo do capital (PRECIADO, 2002). São opostos aparentes, falsos contrastes: tudo o que não é mulher é homem, tudo o que não é homem é mulher, tudo o que não couber nessa classificação é considerado inadequado e desviante.

Entendo que a emancipação do que se entende por mulher náo pode se dar no âmbito do jurídico, sempre ligado aos interesses políticos do estado-nação que reproduzem um sistema baseado em hierarquias, "graus de humanidade" e opressões sociais. Nesse sistema, onde há um aparente espaço democrático para a luta pelos direitos de grupos minorizados, consegue-se criar estratégias micro-políticas de sobrevivência e resistência.

Há muitos feminismos, mas todos eles se originam na percepção de um tipo de opressão. Dito isso, entendo que não há umx únicx sujeitx do feminismo contemporâneo, mas uma pirâmide de opressáo ligada à raça, à classe, e à intolerância dos padrôes impostos pela sexualidade binária. 
O lugar da mulher na música e mais ainda na academia ainda é muito controlado e restrito. Por outro lado, no âmbito da pesquisa contemporânea existe a expectativa de que ao ser feminista sua pesquisa deve ou será sobre feminismo. O que não pode-se negar é que a partir do momento em que as opressóes são percebidas toda ação é pensada e questionada a partir delas. Da mesma maneira, quando percebemos que reproduzimos um sistema colonizador inicia-se um processo de reformulação do mundo, da história e suas narrativas, o qual dura a vida inteira, por ser um processo de embate constante com automatismos e com regimes instaurados.

Apesar de haver muitas pesquisadoras com trabalhos internacionalmente reconhecidos, ainda a maior parte dos professores universitários são homens. Quase todos os meus professores de música, na educação não formal, e logo universitários, foram homens brancos, sem contar as professoras de canto/voz. Porque a voz se refere à carne, ao corpo, portanto à mulher.

Essa realidade configurou a minha escuta e acompanha a minha formação até agora. Entendo que a leitura/escuta de diferentes referências feministas, performáticas e/ou teóricas, e a valorizaçáo da minha experiência como musicista e performer me ajudam a traçar um caminho para descobrir alguns pontos que me interessa destacar nesse texto. Se trata de uma escuta que ao longo do tempo vai sendo destrinchada a partir de estranhamentos em relação às vozes hegemônicas de enunciação, vozes sob as quais o meu corpo vocal foi regulado, vozes que contam a história e que me formam em um entendimento de arte específico que negligencia outras perspectivas.

\section{As Notas sobre a voz}

As Notas sobre a voz são anotaçóes que Meredith Monk realizou ao longo dos primeiros anos de carreira sobre procedimentos presentes nas suas composiçôes vocais e sobre as suas impressóes sobre a voz como instrumento nos seus processos de criaçấo. As Notas foram traduzidas no Brasil pelo artista e pesquisador Conrado Falbo:

$$
\begin{aligned}
& \text { Notes on the voice foi publicado originalmente na re- } \\
& \text { vista literária The Painted Bride Quarterly, no ano de } \\
& \text { 1976, juntamente com o manuscrito comentado da } \\
& \text { partitura da obra "Our lady of late" (Monk, 1976). } \\
& \text { Em } 1997 \text { o texto foi republicado em uma coletânea } \\
& \text { organizada pela crítica de dança norte-americana } \\
& \text { Deborah Jowitt contendo alguns escritos de Monk, } \\
& \text { além de resenhas e artigos sobre sua obra. (FALBO, } \\
& \text { 2014: p.3). }
\end{aligned}
$$

As Notas da artista evidenciam o cruzamento entre a música, as artes cênicas e visuais, a linguística, a psicologia e a filosofia. Ao mesmo tempo, ao localizar as Notas nas vivências da artista, é reconhecível a influência dos princípios budistas nas suas ideias artísticas. Os conceitos apresentados nas Notas geraram desdobramentos bibliográficos que foram escolhidos durante a pesquisa de acordo com aspectos levantados em Key e na minha prática artística. As Notas sobre a voz são também partituras abertas, enunciados da prática da artista, pistas para uma criação a partir das vozes.

Tradução das Notas sobre a voz por Falbo:

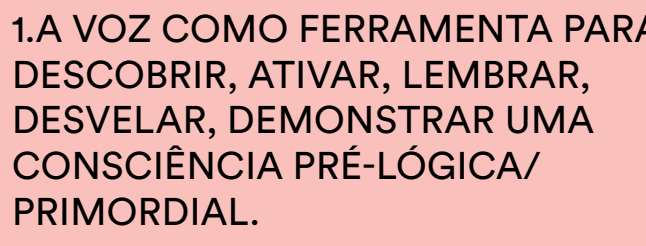

2. A VOZ COMO MEIO DE TORNAR-SE, RETRATAR, CORPORIFICAR, ENCARNAR OUTRO ESPÍRITO.

\section{A VOZ QUE DANÇA. A VOZ TÃO}

FLEXÍVEL QUANTO A COLUNA.

pância nas duas versões publicadas do texto: a publicação de 1976 "laz apenas a palavra na republicação de 1995 pode-se ler o termo "vocal landscape". Optei pela segunda versão por ser mais reveladora do caráter do texto. (FALBO, 2014: p. 3)
4. A VOZ COMO LINHA DIRETA PARA

AS EMOÇÕES. TODO O ESPECTRO DA

EMOÇÃO. SENTIMENTOS PARA OS

QUAIS NÃO TEMOS PALAVRAS.

\section{A PAISAGEM VOCAL. ${ }^{3}$}

6. O CORPO DA VOZ / A VOZ DO CORPO.

7. A VOZ COMO MANIFESTAÇÃO DO SELF, PERSONA OU PERSONAS. 
8. TRABALHANDO COM UM COMPANHEIRO (O INSTRUMENTO ACOMPANHANTE: ÓRGÃO, PIANO, TAÇA ETC.): PADRÕES OU RUIDDO CONTÍNUO CRIANDO UM TAPETE, UMA TAPEÇARIA DE SOM PARA QUE A VOZ POSSA CORRER SOBRE, VOAR POR CIMA DESLIZAR POR BAIXO, PRENDER-SE E ENTRELAÇAR-SE.

\section{A VOZ COMO LINGUAGEM.}

10. INÍCIO - 1967, DUETO DE VOZ SOLO COM ECHOPLEX REVERBERATION UNIT $^{4}$ (BLUEPRINT), A VOZ LIVRE COMO IMPULSO ELÉTRICO. 1968, VOZ (VOZES) E VIOLINO, BERIMBAU DE BOCA (JUICE), A VOZ CRUA (RÚSTICA ${ }^{5}$, LAMENTOSA, PRIMITIVA, AUDACIOSA), CÂNTICOS REPETIDOS; A VOZ COMO INDICATIVO DE PERSONALIDADE - A MULHER DA DE PERSONALIDADE - A MULHER DA MONTANHA VERMELHA, COMO ELA
SOA? CONTINUANDO - 1970, VOZ SOLO COM ÓRGÃO ELÉTRICO (RAW RECITAL, KEY: AN ALBUM OF INVISIBLE THEATRE), A VOZ VIAJANTE (MOVENDO-SE POR PAISAGENS DE SONHO). 1971, ÓPERA ÉPICA (VESSEL), A VOZ DE DEUS (ALTA ${ }^{6}$ TRANSPARENTE, CONTUNDENTE), TELÉGRAFO CÓSMICO; A VOZ COMO FENOMMENO SOBRENATURAL - AS VOZES DE SANTA JOANA, COMO ELAS SOAM?

1972-3, ÓPERA (EDUCATION OF THE GIRLCHILD) A VOZ DE UM SER HUMANO DE 80 ANOS, A VOZ DE UM SER HUMANO DE 800 ANOS, A VOZ DE UM SER HUMANO DE 8 ANOS; RAÍZES CELTAS, MAIAS, INCAS, HEBRAICAS, ATLANTES, ÁRABES, ESLAVAS, TIBETANAS; A VOZ DO ORÁCULO, A VOZ DA MEMORIA. 1972-3, DUETO DE VOZ SOLO COM TAÇA (TAÇA DE VINHO CHEIA D’ÁGUA), (OUR LADY OF LATE), A VOZ NUA, A VOZ FEMININA EM TODOS OS SEUS ASPECTOS; GRADAÇÕES DE SENTIMENTO, NUANCE, RITMO, QUE OUTRA VOZ (PERSONAGEM, PERSONA), OUTRA VOZ (PERSONAGEM, PER A CADA SEÇÃO UM PROBLEMA ESPECÍFICA; TODO O ÂMBITO DA VOZ célebre (eco), tornado norte-americanos a parnorte-americanos a par-
tir da década de 1960. (FALBO, 2014: p. 3)

5 No original: violin, voice (voices) and violin, Jew's harp (Juigh, plaintive, primitive brash), repeated chants; the voice as an indication of character - the red mountain woman, how does she sound? (MONK in JOWITT, 1997: p. 57)

6 Optei por traduzir "high" como "alta", preservar a polissem do adjetivo, que pode ser lido também como "aguda". (FALBO, 2014:
(AFINAÇÃO, VOLUME, VELOCIDADE,

TEXTURA, TIMBRE, RESPIRAÇÃO,

COLOCAÇÃO, FORÇA); A VOZ COMO

VEÍCULO DE UMA JORNADA PSÍQUICA. AGORA -1974, VOZ SOLO COM PIANO (ACÚSTICO) (ANTHOLOGY), A VOZ DA MANHÃ, A VOZ SUAVIZANDO ENQUANTO O SOL LEVANTA, A VOZ DERRETENDO E REFORMANDO-SE MUITAS VEZES EM UMA CANÇÃO; A VOZ COMO MENSAGEIRA OU SIBILA; A MENSAGEIRA DA ALMA.

1975, SOLO PARA VOZ

DESACOMPANHADA (SONGS FROM

THE HILL), A VOZ COMO REFLEXO,

ESPELHO, RECEPTOR DA NATUREZA

VOZES DE ANIMAIS, PLANTAS,

INSETOS, SINAIS, CHAMADOS,

NUSE, SINAIS, CHAMADOS,

NIEROGLIFOS; UMA OFERENDA A

SOZINHA, DESACOMPANHADA, SEM ORNAMENTOS.

1975-6, OPERA (QUARRY7), 30 VOZES CANÇOES DE TODOS OS POVOS -

ACALANTO, MARCHAS, RÉQUIEM

OU LAMENTO, HINOS, CANCCÕES DE AMOR, CANCÕES DE TRABALHO; UM MMMORIAL; CANONS OU SÉRIES UM MEMORIAL, CANONS OU SERIES DE 8 INVISÍVEL NO AR; VOZES DE HOMENS E MULHERES CIRCULANDO, PAIRANDO, MULHERES CIRCULANDO, PAIRANDO,

DESLIZANDO, GOLPEANDO; VOZES

COMO UMA ONDA DE ENERGIA, UMA

LAVAGEM, UMA CURA. (MONK, 2013: P.3)

\section{Algumas considerações sobre a tradução e sobre as Notas} sobre a voz

1) A palavra rough é utilizada no inglês também para se referir a um aspecto tátil. Portanto, eu traduziria a mesma como áspera, como alternativa para a palavra escolhida (rústica). Embora se trate de um adjetivo que envolve o tato, na arte contemporânea, o empréstimo de termos entre as linguagens e sentidos é muito usual nesse caso, como um modo de evidenciar a materialidade do som e a dificuldade de defini-lo, entendendo que os sentidos da percepçáo encontram-se entrelaçados. Há muitos destes termos no âmbito musical, como as categorizaçóes do tempo em estriado e liso empregadas inicialmente pelo compositor Pierre Boulez (1925-2016), ou o termo textura, do qual faço uso para falar em "tapete textural", ao me referir às bases instrumentais e às paisagens sonoras apresentadas por Monk para explorar a voz. Ao
INES: O video dessa ópera_foi restaurado e relançado no dia Nova York.

INÉS: Tradução de Conrado Falbo (2014) do texto Notes on p. 56), republicado no Deborah Jowitt. 
mesmo tempo rough pode se referir ao comportamento de alguém, pode se referir a uma voz incisiva.

O conceito de textura adquire diferentes significados no âmbito da música contemporânea. Em sua pesquisa Textura Musical: Forma e Metáfora (2007), o pesquisador Caio Neto indica três assimilaçóes mais usuais na teoria musical:

$$
\begin{aligned}
& \text { - Tecido aparece em alguns comentários sobre música, e } \\
& \text { refere-se ao arranjo das partes de um trecho de música: } \\
& \text { "Esse efeito, da composiçáo de um tecido musical, já } \\
& \text { foi chamado, apropriadamente, de uma "tapeçaria de } \\
& \text { sons" (PISTON, 411: p. } 1984 \text { ). } \\
& \text { - Encadeamento e ligaçáa são termos técnicos bastante } \\
& \text { utilizados em música, com o sentido muito preciso de } \\
& \text { sucessão. } \\
& \text { - Seu uso na cristalografia, e na Geologia em geral, } \\
& \text { pode ter sido a fonte, a partir do século XX, de certo } \\
& \text { tipo de terminologia, tal como densidade, massa, peso, } \\
& \text { relevo, e outros semelhantes. (NETO, 2007: p. } 7 \text { ) }
\end{aligned}
$$

2) A categorização de uma voz como primitiva sugere que as vozes remetem às vozes de povos originários, vozes ancestrais. De algum modo, a escolha dessa palavra se encontra ligada ao que na antropologia é chamado de primitivismo. Na introdução do seu livro Índios no Brasil (1998), Manuela Carneiro da Cunha menciona "a ilusão do primitivismo" como uma das armadilhas que geram lacunas epistemológicas, apontando a importância de estudos sobre os povos indígenas como sociedades do presente. Segundo ela:

$$
\begin{aligned}
& \text { Na segunda metade do século XIX, essa época de } \\
& \text { triunfo do evolucionismo, prosperou a ideia de que } \\
& \text { certas sociedades teriam ficado na estaca zero da evo- } \\
& \text { luçáa, e que eram portanto algo como fósseis vivos } \\
& \text { que testemunhavam o passado das sociedade oci- } \\
& \text { dentais. Foi quando as sociedades sem Estado se tor- } \\
& \text { naram, na teoria ocidental, sociedades "primitivas", } \\
& \text { condenadas a uma eterna infância." (CARNEIRO } \\
& \text { CUNHA, 1998: p. 11) }
\end{aligned}
$$

Além de considerar as sociedades sem estado como sociedades do presente, projetar a continuidade e suas respectivas formas no futuro é necessário, tanto para sociedades sem estado como para sociedades por ele marginalizadas. Na sua pesquisa "O canto ancestral negro: resistência e protagonismo feminino na cultura negrobrasileira", a pesquisadora Marília Rosa Barbosa apresenta a expressão "Culturas do
Arkhé". Segundo a autora:

usada pelo autor Muniz Sodré para designar as culturas que cultuam a própria vivência; que se fundan na experiência presente entendida năo só como herança mas como continuidade das origens, do "eterno impulso inaugural", da ancestralidade. (BARBOSA, 2015: p. 6)

Em seus estudos da voz, Meredith Monk não menciona uma pesquisa etnográfica das vozes, a partir da escuta de cantos de diferentes contextos, mas uma investigação das possibilidades do próprio corpo vocal. Segundo ela, essa busca possibilita o encontro com diferentes culturas, através de uma espécie de arqueologia da voz. Ao falar de "voz primitiva", Monk se refere a uma voz pre linguagem, e ao mesmo tempo à voz como linguagem, mesmo quando há palavras na expressão vocal, reconhecendo duas linguagens simultâneas. 


\section{A escolha de Key (1971)}

A escolha do disco Key (1971) foi determinada pelo meu interesse nas composiçóes iniciais de Meredith Monk, ao perceber que nessa etapa a artista se encontrava em um processo de experimentação para a criação do repertório vocal que logo estaria presente em seus futuros trabalhos. Isso se relaciona com a potência da prática de quem compóe e ao mesmo tempo performa, tendo que olhar para o próprio trabalho por diferentes ângulos: o planejamento, a experimentação, e a crítica da própria performance como atividades que se retroalimentam. Nessa pesquisa, onde descubro o conteúdo da mesma a partir da escuta da performance e através da mesma, performar e escrever tornam-se praticas que se tensionam e complementam constantemente. A escolha do disco coloca a atenção em um trabalho discográfico que foi pensado de forma contínua e interligada, assim como acontece em Key, álbum definido por Monk como Teatro Invisível.

A poética que a artista propóe nesse primeiro trabalho (1971) e no texto Notas sobre a voz (1976) mostra que o corpo vocal é o que dá início aos seus processos de criação. Nas Notas, Monk entende a voz como parte do movimento do corpo e como um modo de habitar outros corpos e espíritos. Esse entendimento gera perguntas instigantes para essa pesquisa, como por exemplo: Qual é a qualidade emocional dessa peça, considerando que sáo reconhecíveis diversas qualidades vocais? Considerando que a escuta realizada não é ao vivo, mas a partir de uma gravação, como refletir sobre as transformaçōes de um corpo que recriamos a partir da voz? Que corpos estão sendo criados e abandonados durante a peça? Qual é a relaçâo entre vozes e espiritualidade no trabalho de Meredith Monk?

\section{Entre vozes viajantes}

Em Key, Monk cria um ambiente em constante mudança que ela chama de Teatro Invisível:

$$
\begin{aligned}
& \text { PENSEI NISSO COMO TEATRO INVISÍVEL, } \\
& \text { PORQUE A MÚSICA PARECIA SAIR } \\
& \text { DA ESCURIDÃO E DO SILÊNCIO - A } \\
& \text { VOZ TRANSFORMANDO-SE DE UMA } \\
& \text { PERSONAGEM PARA OUTRA, INDO DE } \\
& \text { UM ESPAÇO PARA OUTRO, VIAJANDO DE } \\
& \text { UM NÍVEL DE INTENSIDADE PARA OUTRO. } \\
& (M O N K, 1995)^{\circ}
\end{aligned}
$$

Vozes viajantes é uma traduçáo para Travelling voices, modo em que Monk se refere às vozes em Key. O que conduz as escolhas composicionais de Monk são os caminhos da voz ao longo do disco, tanto nas composiçóes inteiramente vocais como nas que possuem acompanhamento. Os instrumentos criam o que a artista chama de "tapete textural para a voz viajar livremente." Entende-se que essa liberdade é determinada pelo acompanhamento que condiciona a qualidade das vozes, influenciando nas escolhas melódicas, rítmicas e harmônicas das mesmas.

VOCÊ QUER APRENDER A SUA VIDA INTEIRA. EU AMO ISSO, DOLORIDO E TORTUOSO COMO É. É O QUE ME FAZ CONTINUAR. (MONK, 2014: P.124) ${ }^{10}$

9 No original: le theater" because the music seemed to come out of and go into darkness and silence - the voice transforming from one character to another, going from one space to nother, travelling from to another." (Meredith Monk, notas do álbum Key, 1995)

10 You want to love that, as painful and tortuous as it is. It is the thing that keeps me going. (MONK in MARRANA: 2014: p. 124)
Uma rede de desejos vai sendo revelada ao longo da pesquisa; um diálogo entre os depoimentos de Meredith Monk que recolho, o disco Key como exemplo dos trabalhos iniciais da artista, e a minha experiência como musicista e performer. Se trata de uma conversa por mim elaborada, mediada por algumas teorias e presenças musicais e performativas; vozes que hoje reverberam no meu trabalho, e a prática da exploração vocal como uma "usina" de pesquisa.

Para escrever sobre a poética de vozes no primeiro disco de Monk foram consideradas também as composiçôes de imagens e sons iniciais da artista e foi realizada uma pesquisa dos seus textos, junto aos possíveis desdobramentos bibliográficos: sobre exploração vocal, sobre composição, sobre o corpo vocal e as emoções, sobre a filosofia da expressão vocal. 
Paralelamente foi feita uma pesquisa a partir da minha experiência vocal dialogando com os procedimentos apresentados por Monk em Key, e com As Notas sobre a voz. Essa experiência não foi realizada exclusivamente para esse trabalho, mas tem sido construída ao longo dos anos na minha pesquisa artística. Apresento nesse trabalho duas peças da minha autoria. Estas peças não são exclusivamente composiçôes musicais apresentadas em áudio, mas peças onde o dança e/ou o vídeo podem fazer parte do processo de criaçáo, ou tornar-se um e outro ao longo dos anos. Isto se deve ao meu interesse em trabalhar sobre diferentes abordagens e materialidades, e em ressaltar como Monk realiza passagens e traduçôes de uma linguagem para a outra em uma mesma obra. Schloss (1996) discorre sobre essa questão em sua pesquisa Out of the twentieth century: three composers, three musics, one femininity:

Assim como o cinema a música, o movinonto o teatro estâo interligados em um trabalho, Monk muda frequentemente a forma principal em que o "mesmo" trabalho existe. Book of Days, por exemplo, foi uma obra musical, uma performance teatral e, finalmente, um filme; Turtle Dreams foi a primeira peça de teatro, que incluiu um curta-metragem e em 1983 foi recriada como um vídeo de 27 minutos. (SCHLOSS, 1993: p. 11)

Mesmo nesse período em que Monk apresentava em galerias algumas músicas que fariam parte do disco Key (1971) em forma de concerto solo de voz e órgão elétrico, denominado Raw Recital, a artista montava cenários, vestia figurinos, e realizava algumas danças entre as peças musicais como parte de uma única partitura.

Desde o começo dos estudos de Monk, a prática musical e especificamente vocal se encontra entrelaçada na pesquisa de movimento, inicialmente pela prática Dalcroze $^{12}$, logo a influência da dança moderna e ao mesmo tempo da convivência com o Judson Dance Theater e outros grupos e artistas.

A dança moderna americana, desde o seu início no início deste século, tem sido uma série de vanguardas. Cada geraçáo solicitou um novo conjunto de temas, uma nova técnica de dança, uma nova relaçáo com as artes musicais, literárias, visuais e teação com as artes musicais, literárias, visuais e tea-
trais. Na década de 1950 , vários coreografos foram trais. Na década de 1950, vários coreógrafos foram
considerados mais radicais do que os coreógrafos dominantes e professores de dança moderna, como Martha Graham e Jose Timon, Thamyris e Hanya Holm. Merce Cunningham, que tinha sido solista na companhia de Martha Graham, combinou a coluna flexível utilizada na dança moderna com o trabalho de pés do ballet clássico em uma técnica
11 Just as film,
music, movement and theater are intertwined within one work, Monk often changes the principal form in which the "same" work exists. Book
of Days, for example, of Days, for example,
was a musical work, a theatrical performance, Dreams was first a theater piece, which included a short film, and in 1983 was recreated as a $27 \mathrm{mi}-$ nute video. (SCHLOSS, 1993: p. 11)

$12 \quad$ No meu modo de ver, a educaçăo musicompleto na audição, ou em todo caso na percepção do fenômeno musical - mediante o ouvido que se acostuma a captar as relações entre notas, tonalidade inteiro, por e e corpo exercícios especiais, iniciando-se na apreciação da rítmica, a [sic; da] dinâmica e os [sic; dos] coloridos agógicos
da música. (DALCROZE, 1926 apud RODRIGUES, [s.d.], p. 2). O princípio educação musical de Dalcroze é sentir, viver, analisar e intelectualizar, tomando como ponto de partida a relação entre movimentação corporal e ritmo. Dessa forma, musical antodo a prática aprendizado da teoria, da mesma forma como uma criança aprende a língua materna: primeiro a fala e depois seus simbolos. (FERNANDES, 2010, p. 6)
13 American modern dance, since its be ginning at the turn of this century, has been Each generation called for a new set of subjects, a new dance technique, a new relationship to musical, literary, visual, and theatrical arts. By the late 1950s, a number of choreographers were than the dominant modern dance choreographers and teachers, such as Martha Graham, Jose Timón, Tamiris, and $\mathrm{Ha}-$ nya Holm. Merce Cunningham, who had been ham's company, Gombined the flexible spine used in modern dance with the crisp footwork of classical ballet in a technique that was precise and articulate. His experimentation with phy affected the look of his work in a number of ways: It decentralized space, created unexpected and often witty combinations of body parts in movement, and decentralized time in the dance in the sense that (BANES, 1983: p. 16)

14 No original: 1 was not that coordinated as a mover as a little ved with dance saved me. What would I have done if I did not have the movement in my life? I had to find my own way with movement. (MONK in MARRANCA, 2014: $p$ 34) precisa e articulada. Sua experimentaçấo com coreografia aleatória afetou o aspecto de seu trabalho de várias maneiras: decentralizou o espaço, crio combinaçóes inesperadas e engenhosas de engenhosas de partes do corpo em combinaçóes de movimentos, e descentralizou o tempo em dança no sentido de que náo
havia clímax ou desenvolvimentos lógicos. (BANES, 1983: p. 16) ${ }^{13}$

No trabalho de Monk, a percepção das inúmeras possibilidades do som vocal se relaciona diretamente com as práticas corporais, na medida em que se entende a voz também como parte do movimento e como uma força que ocupa e gera espaços, na medida em que o movimento do corpo é também contemplado, nem sempre previamente coreografado ou em evidência, mas disponível para o jogo e os desdobramentos da musicalidade e expressividade da performance vocal.

\section{EU NÃO ERA TÃO COORDENADA COMO UMA BAILARINA QUANDO ERA PEQUE- NA, E ESTAR EM CONTATO COM DANÇA ME SALVOU. O QUE EU TERIA FEITO SE EU NÃO TIVESSE TIDO O MOVIMENTO NA MINHA VIDA? TIVE QUE ACHAR O MEU PRÓPRIO MODO DE ME MOVER. (MONK 2014: P. 34) ${ }^{14}$}

Como cantora, desde que me aproximei da dança, a minha escuta foi modificada. Comecei a perceber as vozes de outra forma, transformando a minha performance vocal e a minha atuação como professora, focando em uma escuta interna, explorando nuances a partir do movimento, da percepçáo de micro-movimentos da respiração, do mapeamento constante dos articuladores da voz e da ação muscular no corpo em cada emissão. Não se trata só de um ganho na percepção, a partir da consciência de como esses sons são produzidos, mas de uma escuta da voz a partir de uma aceitaçáo da mutabilidade do corpo. Entender a partir da experiência do corpo, as possibilidades de ação da voz, e descobrir de que maneira a voz é capaz de criar outros corpos. A exploraçáo vocal é uma experiência de descoberta do prazer que novas emissóes vocais possibilitam. Esse prazer se manifesta em termos de sensações físicas de ressonância e de movimento, e como um campo imaginário, a partir do qual passado, presente e futuro tornam-se camadas da experiência.

Esses outros corpos são entendidos por Monk em Key (1971) como personagens. Nas Notas sobre a voz (1976) a artista menciona também os conceitos de self e persona. Em Vocal Gestures (2003), Monk fala do trânsito pelas diferentes qualidades 
vocais como uma maneira de habitar outros gêneros, sexos e idades.

Em Key as vozes se apresentam valorizando a dimensão espacial das peças; as vozes esbarram criando uma narrativa em diálogo com o órgão elétrico, com o mridingam e com a paisagem sonora.

O trabalho de Monk funciona como um ponto de partida para pensar a voz que se escreve a si mesma durante sua exploração. A prática da exploração vocal possibilita a investigaçáo de sonoridades da voz; a criaçáo de vocalidades a partir de relaçôes com outros instrumentos, texturas e paisagens sonoras; a prática vocal ligada ao desejo do corpo e a uma escuta profunda.

A compositora norte-americana Pauline Oliveiros (1932-2016) entende a escuta profunda como uma escuta atenta, ativa e voluntária. A escuta profunda é uma prática que se destina a aumentar e expandir a consciência do som em tantas dimensôes de consciência e dinâmica de atenção quanto humanamente possível. (OLIVEIROS, 2005: p.23). Monk e Oliveiros possuem um entendimento de escuta similar, considerando que as duas compositoras concebem a prática artística vinculada à prática espiritual e à meditação, e à ligação entre som e emoção.

\section{Sobre as vozes}

Para descrever as vozes nas suas diferentes características materiais parto da minha experiência como aluna e professora em diferentes âmbitos do ensino de voz, no Brasil e na Argentina, e considero algumas nomenclaturas e reflexôes que as pesquisadoras e professoras Regina Machado (2007) e Joana Mariz (2013) apresentam nos seus trabalhos acadêmicos. Embora estas pesquisas estejam focadas em abordagens vocais do canto erudito e popular, considero relevantes esses trabalhos; o primeiro por trazer categorias de análise, como as dimensões técnica e física, e o segundo por se tratar de um estudo focado nas terminologias utilizadas por profissionais da voz no Brasil, e por ter sido escrito por uma cantora/fonoaudióloga/professora que possui experiência com o Somatic Voice Work (Lo Vetri), técnica estudada por Meredith Monk durante alguns anos nos Estados Unidos.

Sobre questōes técnicas referentes a outros usos da voz recorro às pesquisas "21 Century Voice" (2004) de Michael Edward Edgerton, "When words are not enough" (2008) de Melanie Austin Crump e ao artigo sobre técnicas estendidas da voz de Deborah Kavash (1980). Ao longo do estudo sobre os trajetos das vozes faço uso também de símbolos fonéticos. Contudo, não desejo afirmar a voz como uma substância da linguagem ou mesmo reduzi-la à matéria significante, mas fazer uso de uma ferramenta gráfica a partir da qual podem-se reconhecer certos sons que são estudados pela linguística, podendo a partir desse conhecimento isolar sonoridades, prolongá-las, deformá-las, mesmo quando não se possui o domínio verbal de uma língua específica. ${ }^{15}$ 


\section{Percurso do trabalho}

Esse trabalho possui três capítulos. No primeiro capítulo realizo uma apresentação da obra de Meredith Monk e dos aspectos da mesma que abordarei mais de perto. Discorro também sobre o contexto em que Key (1971) foi gravado e lançado, e sobre algumas questōes técnicas e filosóficas de Key, no que se refere ao Teatro Invisível, à espacialidade e à continuidade apresentada no disco. Em seguida, distingo os modos de exploração vocal de Monk, separando as peças em procedimentos, alguns anteriormente nomeados pela artista, e outros organizados por mim durante a pesquisa.

No segundo capítulo relaciono cada uma das faixas escolhidas com uma das Notas sobre a voz para refletir sobre as mesmas. No total são apresentadas as seguintes sete faixas: Porch (faixa um), What does it mean? (faixa três), Fat Stream (faixa cinco), Vision (faixa seis), Do You Be (faixa sete), Change (faixa nove) e Dungeon (faixa dez). Nesta seçáo do texto apresento depoimentos de Meredith Monk e da artista Lanny Harrison sobre o próprio trabalho, referências ligadas à prática de Monk, como o Budismo Zen, e referências bibliográficas que auxiliam na reflexão que as Notas sugerem, como textos de Adriana Cavarero, Antonin Artaud, Paul Zumthor, Leda Valladares, Mladen Dolar, Laura Beatriz Backes, Meran Vargens e outras autoras. Esta parte do trabalho combina análises técnicas das vozes apresentadas, sensaçôes pessoais a partir da escuta de cada peça, desdobramentos bibliográficos a partir do enunciado escolhido para cada peça e depoimentos de Meredith Monk.

No terceiro capítulo realizo um breve relato da minha experiência no curso Voice as Practice (2017), conduzido por Meredith Monk e Ellen Fischer, e exponho duas peças criadas em diálogo com os procedimentos previamente apresentados no trabalho de Monk, ressaltando as diferentes abordagens e as reflexôes sobre as experiências realizadas. A primeira peça surge da minha relação com a poesia Una mirada desde la alcantarilla da escritora argentina Alejandra Pizarnik (Buenos Aires, 1936 1972), publicada no livro "El árbol de Diana" em 1962. A peça foi se transformando ao longo do mestrado, tomando diferentes formas; no trabalho vocal, na pesquisa de movimento, na investigação das possibilidades em um formato audiovisual, entre outras. Essa peça foi apresentada e adaptada para contextos muito diferentes, como o Centro de Referência da Dança de São Paulo (2018), a Universidade Federal do Sul da Bahia (2018), a sala Eden's Expressway (2018) no marco do evento Open Performance, e o Judson Church (2019) em Nova York. A segunda peça se refere a ideia de Monk de "Paisagem Vocal", apresentando um contraponto de vozes com motivos repetitivos que vão transformando a sua sonoridade, assim como a artista realiza em Change (faixa nove). Neste capítulo utilizo uma das Notas da Voz (A voz do corpo/o corpo da voz) de Meredith Monk para iniciar uma reflexão sobre a investigação de vocalidades desde uma perspectiva crítica à formação vocal tradicional atrelada à inscrição sexo/gênero, por meio das pesquisas de JACOBS (2015), PRECIADO (2002), EL HAOULI (1993) e outras. Para essa reflexão apresento também depoimentos de artistas de vários contextos artísticos e nacionalidades, artistas que trabalham com a exploraçấo da voz nos processos de criação. No final do capítulo discorro sobre a prática de exploraçáo vocal como processo da performer criadora e sobre o conceito de técnicas estendidas da voz desde uma perspectiva histórica. 


\section{Apresentação}

A TRADIÇÃO EUROPEIA ERA A ÚNICA QUE SEPARAVA ESSES ELEMENTOS, ENTÃO CANTORES CANTAM, ATORES ATUAM, BAILARINAS DANÇAM. EU SENTI QUE ERA TAMBÉM UMA FORMA DE CURA DA FRAGMENTAÇÃO DA NOSSA SOCIEDADE, A MANEIRA EM QUE JUNTAVAMOS ESSES A MANENTOS E CRIAVAMOS UMA FORMA INTEIRA, ESTAVAMOS AFIRMANDO NÃO SÓ A RIQUEZA DA PERFORMANCE MAS TAMBÉM A RIQUEZA DO PÚBLICO MAS TAMBÉM A RIQUEZA DO PÚBLICO

$\left(\right.$ MONK, 2017) ${ }^{16}$

\section{CAPÍTULO I}

Meredith Monk
No intuito de desenvolver um repertório vocal que seja tão flexível quanto as articulaçôes do corpo, Meredith Monk investiga vocalidades criando discos, óperas, danças, obras site-specifics e produçôes áudio - visuais. Esta flexibilidade da voz transcende a linguagem verbal, valorizando a voz como um meio potente para a descoberta de um amplo leque de sonoridades e como início do processo de criaçáo.

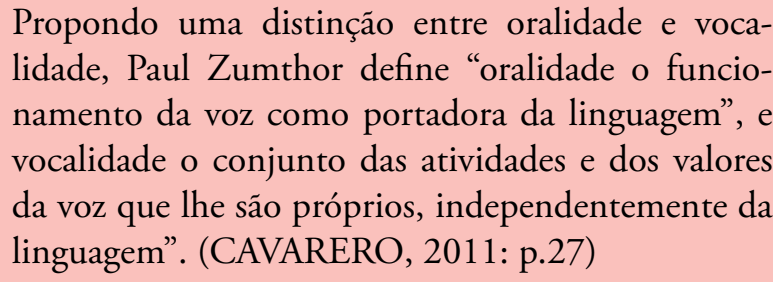

Monk evidencia as qualidades simbólicas do som, entendendo que o som vocal possui uma relaçáo direta com as emoçôes e que ela é um instrumento original e espiritual, a partir do qual pode-se expressar mais diretamente do que com palavras. Dificilmente seu repertório vocal apresenta palavras, e quando estas fazem parte das peças, a escolha é feita principalmente pelas suas características sonoras. No entanto, a artista assume no seu trabalho uma voz carregada de histórias e fundamentalmente de experiências do corpo.

$$
\begin{aligned}
& \text { DE ALGUM MODO, O MUNDO DA } \\
& \text { DANÇA ERA MAIS AVANÇADO DO QUE } \\
& \text { QUALQUR OUTRO MUNDO NESSE } \\
& \text { MOMENTO. AS PESSOAS CONSEGUIAM } \\
& \text { ENTENDER O QUE EU ESTAVA FAZENDO. } \\
& \text { MAS NA VERDADE, NÃO ME VEJO } \\
& \text { COMO BAILARINA DESDE } 16 \text { MILLIMETER } \\
& \text { EARRINGS EM DIANTE. DESDE ENTÃO } \\
& \text { EU SOUBE QUE ERA UMA ARTISTA DO } \\
& \text { TEATRO, TEATRO NO SENTIDO MAIS } \\
& \text { AMPLO DA PALAVRA. SABIA QUE QUERIA }
\end{aligned}
$$


CRIAR UMA FORMA VISUAL DE TEATRO. QUERIA CRIAR UM TEATRO DE IMAGENS.

(MONK, 2014: P.15)

Graduada da Escola Sarah Lawrence (Yonkers, NY) em 1964, onde realiza uma formação interdisciplinar, Meredith Monk se instala na cidade de Nova York onde encontra um ambiente artístico efervescente com o grupo Fluxus, a Arte Pop, o cinema e o teatro experimental, os happenings, o grupo Judson Dance Theater, entre outros.

\section{EU TENHO MUITA GRATIDÃO AO POVO DO FLUXUS. ELES FORAM MUITO RECEPTIVOS COMIGO QUANDO CHEGUEI A NOVA YORK. EU ACHO QUE ELES VIRAM O QUE EU TINHA COM TODAS AS DIFERENTES POSSIBILIDADES DE FORMA. EU PODERIA CANTAR, EU PODERIA ME MOVER, EU ERA UMA ATRIZ. E ENTÃO MOVER, EU ERA UMA ATRIZ. E ENTÃO ELES ME PEDIRAM PARA TOCAR EM SUAS DIFERENTES NÃO ERAM UM GRANDE PROBLEMA PARA ALGUÉM COMO DICK HIGGINGS. ELE TAMBÉM ERA UM MÚSICO MARAVILHOSO, ELE É UM ATOR MARAVILHOSO, E ENTÃO, QUANDO ELE TERMINOU SE APRESENTANDO COMIGO, TERMINOU SEAPRESENTANDO COMIGO, COM SEU CORPO, COM O SEU COM SEU CORPO, COM ESTILO. (MONK, 2014: P. 12) ${ }^{18}$}

Naquela época Monk realizava algumas performances no Judson Memorial Church criadas por ela e em colaboração com artistas do grupo Fluxus. O Judson Church foi um espaço muito importante para pensar dança e performance art na cidade de Nova York. Em “Democracy's Body: Judson Dance Theater 1962-1964" (1983), a pesquisadora Sally Banes discorre sobre este espaço:

Uma congregação protestante liberal que ficava no extremo sul da Washington Square em Greenwich Village. Lá, o ministério e os paroquianos há muito atuavam na reforma política, nos direitos civis, e nas atividades artísticas. O espaço, que já abrigava $\mathrm{Ha}$ ppenings, assim como o teatro dos poetas de Judson, as exibiçōes de filmes e a Judson Gallery, onde foram realizadas exposiçóes de arte pop e política, a Judson Church, logo se tornou o centro de dança de guarda da cidade. (BANES, 1983: p. 11) ${ }^{19}$
19 A liberal protestant congregation south end of Washingto Square in Greenwich Village. There the ministry and parishioners had form politics, civil rights, and arts activities. Already the site of Happenin$\mathrm{gs}$, the Judson's poet's theatre, film screenings, at the Judson Gallery, where exhibitions of Pop held the Judsons ch soon also became the center for avant-garde dance in the city. (BANES, 1983: p. 11)

In a way, the advanced than any other world at that time. People could see what did not identify myself a dancer and choreographer from 16 Millimeter Earrings on. From then on I knew that I was theatre artist, theatre in the largest sense of the A, 2014: $p$ 15) have so much gratitude were very welcoming to me when I first came to New York. I think they saw what I had with bilities of form. sing, I could move, I was na actor. And so they asked me to perform in their pieces. I think the fact of these different modes was not a big deal to someone like Dick Higgings. He also wa himself and a wonderful actor, and then when he ended up performing with $\mathrm{me}$ he was a grea mover with his body, in his own way. (MARRAN-

The Cunningham-Cage collaborainflus an important Dance Theater. The dancers learn from Cage's teachings-his interest in Zen Buddhism, in moving from music towars theater, in the wrintings of Antonin Artaud, in chance the everyday. (BANES, 1983: p. 16)

21 No original: No to spectacle, no to virtuosity, no to transformations and magic and make-believe no to the dence of the star image no to the heroic no to the anti-heroic no to trash imagery no to involvement of performer or spectator no to style no to camp no to seduc tion of spectator by the no to eccentricity no to moving or being moved. From 'No Manifesto, 1965. Reprinted in Yvonne Rainer, Feelings are Facts, Cambridge, MA and London: The MIT
Em 1960 um grupo de artistas se reuniu para participar de aulas com o artista Robert Dunn no studio de Merce Cunningham no prédio do Living Theater. Em julho de 1962 o grupo realizou uma primeira apresentaçáo gratuita baseada nesses encontros. A apresentação foi chamada Dance\#1 e aconteceu no Judson Memorial Church. Esse foi o começo de uma ocupação artística no local por meio de concertos de dança, aulas e colaboraçóes artísticas entre o grupo e outras artistas da cidade. Uma das principais características do grupo era a rejeição dos códigos do ballet e da dança moderna, considerando todo movimento cotidiano uma dança possível. O grupo foi fortemente influenciado pela colaboração entre Cunningham e Cage.

$$
\begin{aligned}
& \text { A colaboraçáa Cunningham/Cage foi uma impor- } \\
& \text { tante influência para o Judson Dance Theater. Os bai- } \\
& \text { larinos aprenderam dos ensinamentos de Cage-- seu } \\
& \text { interesse em Budismo Zen, em se mover da música } \\
& \text { para o teatro, nos escritos de Antonin Artaud, nos } \\
& \text { métodos do acaso, no valor do cotidiano. (BANES, } \\
& \text { 1983: p.16) }
\end{aligned}
$$

Durante esses anos, os parâmetros da performance estavam sendo repensados pelo New York's Judson Dance Theater. Em 1965, a artista Ivonne Rainer do Judson Theater realizava seu "No manifesto", a partir do qual evidenciava o afastamento dos princípios dramáticos do teatro. Ivonne Rainer declarava:

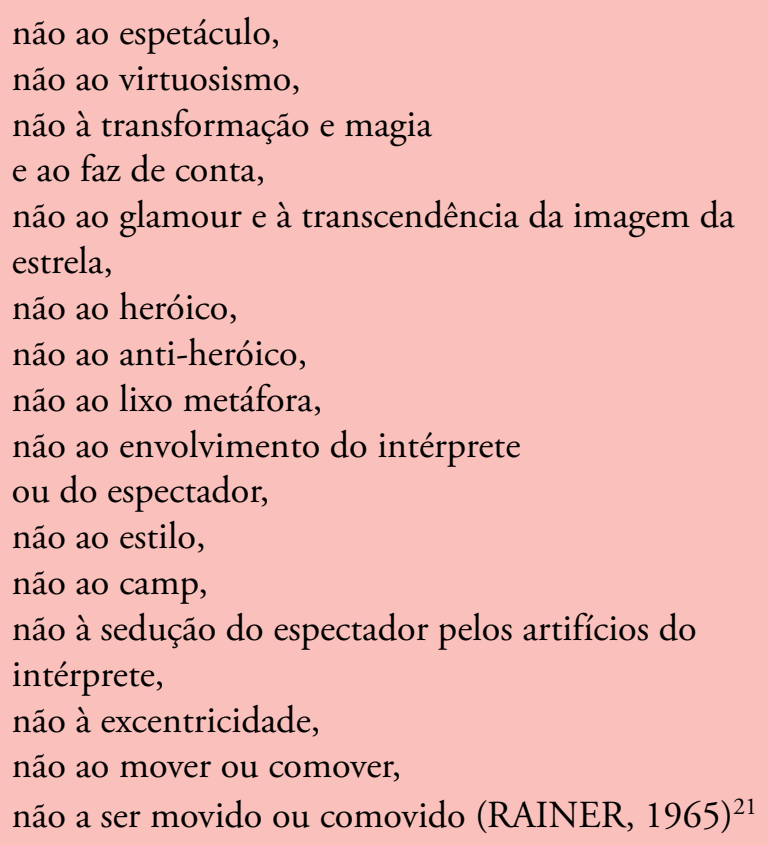

Frente ao manifesto de Rainer, Monk desenha seu próprio caminho. Nas palavras da artista: 
EU ESTAVA LUTANDO COM O JUDSON DANCE THEATER NA MINHA MENTE. NO MOMENTO EM QUE RAINER DIZIA 'NÃO’ PARA A TEATRALIDADE, EU DIZIA 'SIM'; ELA DIZIA 'NÃO' PARA A MAGIA, EU DIZIA 'SIM' PARA A MAGIA; 'NÃO' A TRANSCENDÊNCIA' 'SIM' A

TRANSCENDÊNCIA. (MONK, 2010)22

Monk não se afastaria do teatro que possibilita outras realidades, que cria ilusão entre espectador e performer, do teatro da representação, da ressignificaçáo de objetos em cena e da investigação de diferentes expressōes vocais não usuais. Entretanto, incorporaria no próprio trabalho outros elementos próprios do teatro performativo como a valorização de movimentos corporais cotidianos e o trânsito por diferentes cenários ou perspectivas espaciais fora do palco, e/ou pensadas para o um espaço específico, por exemplo, em Juice (1969), Vessel (1971), em Songs of ascension (2011) ou em Cellular Songs (2018).

As sonoridades das vozes de Monk longe se encontravam da fala, da própria língua ou mesmo de uma voz treinada em um único tipo de emissão vocal. As vozes da artista se aproximavam mais de uma exploração sensorial que permitia uma descoberta constante, onde procurava-se não assumir com antecedência o que um corpo deve ser e/ou expressar. Segundo Banes (1983) o mais importante na pesquisa do Judson Dance Theater era "a atitude de que todo podia ser visto como dança; o trabalho de um artista visual, de um cineasta, de um músico". No seu trabalho, Monk reconhece a influência da professora Bessie Shoenberg no desenvolvimento de uma visão aberta em relação às definiçōes das artes.

ELA TAMBÉM ENSINOU A TODOS NÓS A SERMOS RESPEITOSOS UM COM O OUTRO - PARA APRECIAR OS TALENTOS, ESTILOS E FASES DE CRESCIMENTO DE CADA PESSOA, EM OUTRAS PALAVRAS, NÃO TER UMA IDEIA PRECONCEBIDA DO QUE É UM CORPO, UMA DANÇA É, UMA MÚSICA É, UMA PEÇA É. ESSA ATITUDE BÁSICA ME DEU A CORAGEM DE TENTAR ENCONTRAR NOVAS FORMAS DE JUNTAR AS FORMAS DE ARTE TRABALHANDO ENTRE AS RACHADURAS, ENSINOUME A NUNCA ASSUMIR NADA, FEZ DO ME A NUNCA ASSUMIR NADA, FEZ DO
$23 \quad$ No original: She also taught all of us to be respectful of each other - to apreciate each person's particular talents styles, rates fo growther words, not to have a preconciebed idea of what a body is, a dance is, a song is, a play is. This basic atittude has given me the courage to try to find new ways of putting art forms toge the cracks, it has taught me to never assume anything, it has made the process of discovery one of the great joys of my life and it has kept me curious. Meredit Monk/Sarah Lawrence ch, 1985.

24 INÉS: Dança clássica indiana.

25 INÉS: Dança dramática japonesa. $26 \quad$ No original: In
$1964-66$ I was thinking more about Chinese opera and Kathakali, Kabuki theater, and trying to get back to a sensory integration the West. A sense of theater as a ritual or a celebration, of wonder-a triangle that included drama, music and dance (MONK in JOWITT,
GRANDES ALEGRIAS DA MINHA VIDA E ISSO ME MANTEVE CURIOSA. (MONK $1985)^{23}$

Embora influenciada pela simplicidade do ordinário promovido pelo Judson enquanto dança, as vozes de Monk carregam uma teatralidade no sentido de chamar a atenção para outros modos de comunicação não verbais, partindo do cotidiano no corpo para transcendê-lo a partir da flexibilidade vocal e de outros elementos em cena. Nessa perspectiva, Monk se nutre também de outras formas dramáticas:

EM 1964-66 EU ESTAVA PENSANDO MAIS
NA ÓPERA CHINESA E EM KATHAKALL ${ }^{24}$,
KABUKI THEATER ${ }^{25}$, E TENTANDO VOLTAR
A UMA INTEGRAÇÃO SENSORIAL
QUE NÃO TEMOS NO OCIDENTE. UM
SENSO DE TEATRO COMO UM RITUAL
OU UMA CELEBRAÇÃO, DE ILUSÃO -
UM TRIÂNGULO QUE INCLUÍA DRAMA,
MÚSICA E DANÇA. (MONK APUD JOWITT,
1997: P.80)

Como consequência desse interesse por um tipo de obra total, surge uma pergunta central no desenvolvimento da sua obra: como integrar todos esses elementos em uma forma? A integração entre os elementos que compóem a sua obra se relaciona com o aspecto social das suas peças. Esses aspectos se encontram explícitos nos assuntos que a artista aborda ao longo da sua carreira, como o antissemitismo, o exílio e o holocausto (Quarry - ópera), a contemporaneidade e a idade média (Book of days - filme), as questôes de gênero (Paris - performance), os estágios na vida das mulheres (Education of the Girl Child - ópera), limites físicos e mentais no trabalho performático (16 Millimeter Earrings).

$\mathrm{Na}$ época em que foi lançado o LP Key (1971), Monk já tinha criado peças como Break (1964), 16 Millimeter Earrings (1966), Blueprint (1967), Dedicated to dinosaurs (1968), Barbershop (1969), Juice (1969). Nasceria ao mesmo tempo sua ópera épica Vessel (1971), surgiria um ano depois a peça intitulada Paris (1972) em duo com o artista de bricolagem Ping Chong, e lançaria Our lady of late (LP produzido também pelo produtor de Key: Collin Walcott) um ano mais tarde (1973).

No livro editado pela pesquisadora Deborah Jowitt há uma cronologia da
grafia e da obra completa da artista. A primeira gravação mencionada data de my mind. At the ther in Rainer was saying ' $n$ ' to 'yes'; she was saying 'no' to magic, I was saying 'yes' to magic; 'no' to transcendence, 'yes' to transcendence. (MONK in LEAVER-YAP, 2010) 
um single do ano 1967 chamado "Candy Bullets and Moon". O primeiro disco lançado após esse single é o álbum o Key (1971). Antes de lançar esse álbum, Monk já realizava concertos intitulados Raw Recital que continham algumas músicas de Key. $\mathrm{O}$ primeiro Raw Recital foi apresentado no museu Whitney. No seu livro "Terpsichore in Sneakers (1980)" a historiadora da dança Sally Banes faz a seguinte resenha:

Em 1970, ela apresentou um concerto de música no Whitney Museum, o primeiro de muitos Raw Recitals. Esses recitais sempre têm um quadro teatral; no primeiro, Monk satirizou uma diva, cuja aparência ficou mais estranha à medida que a música progredi de Bach para Monk. Vestida com um vestido rosa extravagante e botas de trabalho vermelhas, o cabelo arrebitado, ela fragmentou os gestos usuais da cantora, parou abruptamente quando uma assistente prendeu um corpete sobre ela. Aos poucos, o cabelo pre dela cain. A pla mentou pela sala de concertos. A másica de Monk sempre táo integrante das peças teatrais quanto seu senso de teatralidade é para os recitais de música, tem sido chamada de reminiscência de Satie, ou de cânticos hebraicos, ou de chamadas de Muezzins. Tem uma qualidade folclórica simples, muitas vezes com uma margem nasal; melodias repetitivas, consistindo em cadeias circulares de pequenas frases, são usadas nas harpas judaicas, nos kazoos, nas taças de vinho ou nos teclados. Os acordes repetidos, exploving au nos céplovoz circulando, torcendo, viajando. (BANES, 1987: p. $154)^{27}$

Monk compôs música vocal que ela mesma canta como solista, música para os seus grupos vocais e música para outros instrumentos. Quase sempre a artista está envolvida no processo de composiçấo também como performer, principalmente nesta primeira etapa da sua carreira, final dos anos sessenta e começo dos setenta.

Em 1968 Monk funda The House, seu espaço de trabalho, uma companhia dedicada a explorar artes interdisciplinares, na época junto aos artistas Ping Chong, Lanny Harrison, Blondell Cummings. The House funcionava de maneira colaborativa, cada artista poderia contribuir com materiais e ideias. Em entrevista ${ }^{28}$ que realizei com a artista Lanny Harrison, ela diz:

The House era uma coleção de seres táo diferentes. Eu vim como dançarina, personagem, atriz, mímica, artista visual, havia um cientista, um cineasta, um
30 INEÉS: Allison Easter,Theo Bleckmann Tom Bogdan, Janis Brenner, Sidney Chen, Ching Gonzalez, Andrea Goodman, Lanny Harrison, Bohdan Hilash, Joh mecker, Jo stewart, Pablo Vela, Randall Wong Nomes que aparecem $n$. site de Meredith Monk como participantes do grupo vocal em diferentes períodos da carreira

31 I formed $\mathrm{Me}$ ( as a trio of women and evolved into a sexteto of three women and three men. Over the years, we have developed a prothat allows for the unique qualities of each person's voice and humanity to come through. (MONK, 1990: p. 2)

$32 \quad$ Composing for her vocal ensemble, Monk proceeds much as choreographer does, coming to rehearsal, modules sketched out, building material in rehearsal directly on the performers, writing traditional notation-only 1997: p.13) 28 INEES: Entrevista de 2019 por meio de um formulário enviado para a piece down-rarely in

professor de teatro, um pintor. Eu ainda faço parte - trabalhando com Meredith Monk agora no renascimento de Quarry. Todo esse trabalho é sempre de interesse - uma ótima combinąáo da melhor músca, teatro, ambiente, personagens. The House era um microcosmo do mundo, habitada pelos seres mais

Em 1978 Monk forma seu grupo vocal. Ativo até hoje, e atualmente integrado pelas artistas Allison Sniffin, Ellen Fisher e Katie Geissenger, o grupo já teve diferentes formaçóes ${ }^{30} \mathrm{e}$ é um importante laboratório de ideias para pôr em prática as peças vocais mais contrapontísticas da compositora.

\section{FORMEI O MEREDITH MONK'S VOCAL \\ ENSEMBLE, QUE COMEÇOU COMO UM \\ TRIO DE MULHERES E SE DESENVOLVEU \\ COMO UM SEXTETO DE TRÊS MULHERES \\ E TRÊS HOMENS. AO LONGO DOS ANOS, \\ TEMOS DESENVOLVIDO O PROCESSO DE \\ CRIAR MÚSICA QUE PERMITE AS QUALI- \\ DADES ÚNICAS DA VOZ DE CADA PES- \\ SOA E SUA HUMANIDADE EMERGIREM. \\ (MONK, 1990: P. 2) ${ }^{31}$}

No início do processo de criação, Monk costuma passar um longo tempo sozinha, idealizando o que logo será compartilhado com o grupo. No entanto, os processos composicionais de Monk, no âmbito do seu grupo vocal, sempre foram colaborativos, na medida em que os ensaios funcionam como um espaço para o levantamento de ideias a partir de um material preconcebido pela artista. Desta maneira, a obra é desenvolvida a partir da potencialidade do grupo. Deborah Jowitt comenta esses processos no seu livro sobre Monk:

\section{Compondo para o seu grupo vocal, Monk trabalha como uma coreógrafa, chegando ao ensaio, talvez, com pequenos módulos esboçados, construindo material de ensaio diretamente junto aos artistas, redigindo uma peça - raramente na notaçáo tradi- cional - somente depois de configurada. (JOWITT

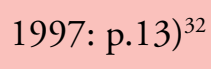

Em relação à dança do corpo Monk se considera menos rigorosa. Embora as 
mas peças as vozes e o movimento são elaboradas juntas, e em outras Monk descobre e explora a movimentação após a composiçẫo das vozes. Segundo a artista:

\section{TRABALHO NA MÚSICA COMO TRABA- LHO NA DANÇA, O QUE QUER DIZER QUE TRABALHO DIRETAMENTENASPROPRIAS PESSOAS. DIRTA A MÚSICA PARA SUAS PESOAS. CRIO A MUUSCA PARA SUAS É E MAIS LIGADO A DANÇA QUE A MÚSICA (BLACKWOOD, 1980, TRANSCRIÇÃO DE CONRADO FALBO).}

Essa proposta se relaciona com a seguinte questão: o que um corpo a partir das suas particularidades e da sua história tem a dizer/manifestar? Isto seria o contrário de partir de uma ideia de como este corpo deve se comportar, ou como este corpo deve atingir certas formas para conseguir ser chamado de corpo dançante ou cantante. Mesmo que na composição musical seja frequente compor para uma voz específica, ou no caso da música erudita, para uma categoria de voz específica, a tradição no âmbito da composição europeia, sempre provocou que as vozes/interpretes tivessem que atingir certas expectativas dos compositores; habitar uma proposta de corpo, um ideal pautado pelas vozes hegemônicas de enunciação. O fato de Monk trabalhar com "as vozes particulares" indica que, embora certas emissóes vocais e melodias sejam propostas, cada voz trabalhará a partir da sua flexibilidade e potência, inclusive propondo variaçóes e criando vozes próprias.

Na obra de Meredith Monk, as perguntas iniciais serão o núcleo de todo processo de criação da obra, como por exemplo:

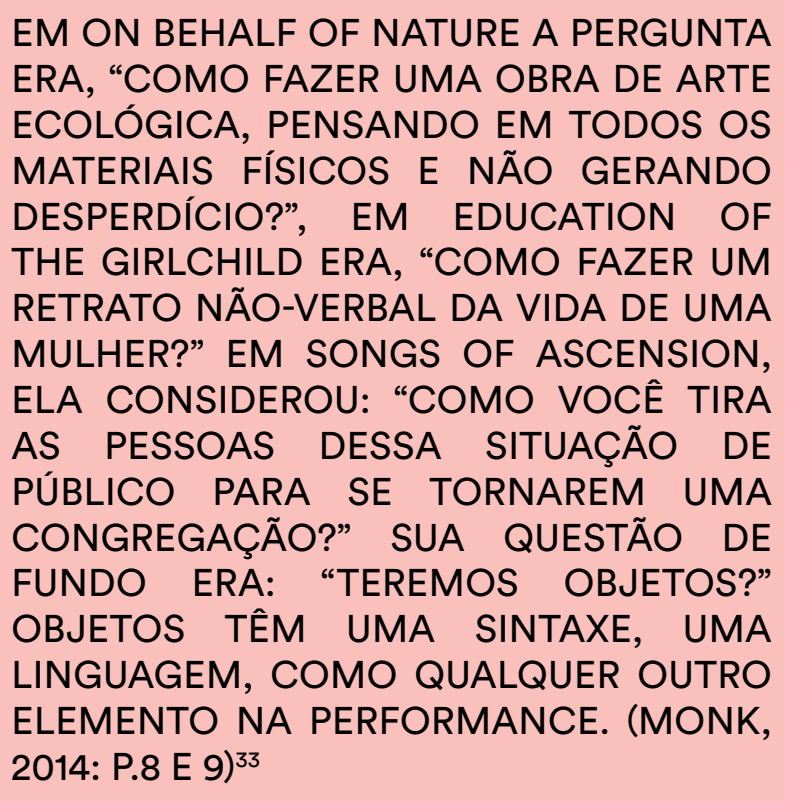

33 No original: question was, "How do you make an ecological artwork, thinking of all the physical materials te?", For Education of the Girlchild it was, "How do you make a non-verbal portrait of one woman's life?" For Songs of Ascension, she considered How do you get people out of that audience gregation?" Her bottom line question: "Are we going to have objects?" Objects have a syntax, a language, like every other element in performance." (MARRANCA, 2014: p.8 e 9)
$34 \quad$ How do you make a piece that has vocabulary of cinema? How would you do that as a live person with the continuity of only one person? Very quick changes of intensity, of focus. A very disconnected kind of piece, but with a continuity of a live, solo person. (MONK in MARRANCA, 2014: $p$ 6)

5 O primeiro concom dança foi quando tinha dezoito anos, ela participava de um grupo de performance de danças folclóricas judaicas. MARRANCA, 2014:
Pensar na espacialidade e na arquitetura, pensar na voz como se pensa numa pintura ou em uma escultura, com nuances de luz, transparências e texturas, pensar a voz como um modo de apresentação e representação de uma vida, como criadora de espaços, e em relaçáo com os instrumentos e objetos que a artista escolhe. No trabalho de Monk tudo parece se desenvolver a partir do conteúdo da voz.

A preocupação focada na recepção e na ação do público se relaciona com mudanças no teatro a partir dos anos sessenta. "No teatro o performativo passa a designar um espaço e compartilhamento entre artistas e audiência, e não de obra acabada e observação passiva." (JACOBS, 2015) Desta maneira, há uma projeçâo também da ocupação do espaço pensada para o público, sendo convidado a fazer parte das peças. Assim como na música de John Cage, o processo e o acaso ganham um outro valor e tratamento, entendendo o potencial da performance que envolve o público e os acontecimentos. Ao mesmo tempo, Monk encontra no cinema um desafio interessante para o seu trabalho performático, ao se perguntar:

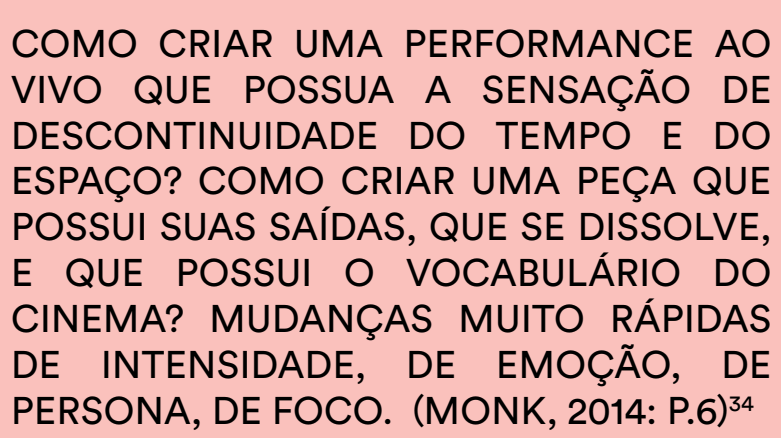

Monk cria um vocabulário próprio onde a voz migra continuamente e possibilita o trânsito entre corpos em uma mesma performance. A partir da exploraçáo vocal, seus trabalhos transparecem o poder imagético do som e da voz, migrando gradativa e/ou abruptamente de uma qualidade vocal para a outra.

Entre a permeabilidade do experimentalismo do pós-guerra norte-americano, entre a influência da música judaica ${ }^{35}$, entre a experiência com a dança moderna e o contato com o Judson Dance Theater, a performance art, o seu interesse no teatro oriental, e a partir do entendimento da prática artística como prática espiritual, Monk desenvolve composiçôes de imagens, sons e movimentos.

O trabalho da artista revela a ideia de composiçáo a partir de uma voz que experimenta; peças vocais que surgem de uma contínua exploraçáo do corpo vocal, investigando diferentes tipos de emissão, sem as limitaçôes da classificação vocal her- 
dada da música de concerto europeia, nem as amarras das formas da música erudita e/ou popular, porém sempre revisitando a forma canção.

Segundo o medievalista Paul Zumthor, "a voz desaloja o homem do seu corpo, atravessando o limite do mesmo sem rompê-lo" (ZUMTHOR, 2000) Se a voz depende do corpo para se materializar e ressoar nos corpos e no espaço, ao mesmo tempo cria outros corpos a partir das possibilidades do som, que transcendem a localização pessoal. Nas Notas sobre a voz (FALBO, 2013) Monk sugere este fenômeno ao definir "a voz como meio de tornar-se, retratar, corporificar, encarnar outro espírito, e a voz como manifestação do self, persona ou personas" (MONK, 1997)

No trabalho de Monk a estranheza vocal é atingida a partir da ênfase na voz que transita por diferentes consistências sonoras na sua exploraçáo, vocalidades de seres dificilmente classificáveis sob a distinçâo sexo/gênero ou do entendido como humano. Há outras artistas cujas investigaçōes são referências centrais na experimentação vocal contemporânea, como Cathy Berberian (Estados Unidos, 1925-1983), Yoko Ono (Tókio, 1933), Phil Minton (Inglaterra, 1940), Demetrio Stratos (Grécia, 1945-1979) e Joan La Barbara (Estados Unidos, 1947).

A pesquisa de vocalidades e a exploração vocal no processo composicional destaca as qualidades materiais das vozes, evidenciando o trânsito entre as mesmas. No entanto, como aponta Falbo em sua pesquisa, o foco nas vozes para além das palavras em Monk náo parte de um interesse pelo entendimento das vozes como estudo científico do som, mas como experiência dos corpos e da relação entre vozes e emoçôes.

Em Monk, a exploração vocal se dá principalmente na investigação das possibilidades do corpo, independentemente de ferramentas tecnológicas ou acessórios. "Agora, depois de trabalhar todos esses anos com a voz, percebi que a voz pode fazer quase tudo o que os eletrônicos podem fazer. Me mantive afastada dos eletrônicos" (MONK, 1997).

Desta maneira, a voz se reinventa em relação com o contexto sonoro, industrial e eletrônico, transitando entre a harmonia e a inarmonia do som vocal, mesmo quando não são utilizados acessórios digitais ou analógicos. Me refiro aqui a uma voz que consegue trabalhar com a ideia de melodia e harmonia da música de concerto tradicional e ao mesmo tempo uma voz que explora também seu aspecto mais ruidoso e apresenta sonoridades não definidas pela denominação de nota ou altura, se apresentando também de forma inusitada na sua variaçáo náo harmônica e caótica. Este entendimento é possível por uma busca contínua das possibilidades da voz. Ao mesmo tempo, esta voz, não necessariamente vinculada às línguas verbais, já é ruído, sussurro, máquina. A voz inacabada é desvendada pelo interesse e desejo deste corpo, sob as circunstâncias específicas do seu campo de ação.

Monk explora a voz em um amplo espectro de respiraçôes e ressonâncias, assim como também combina aspectos visuais e gestos que apresentam questionamentos em relação ao que se espera socialmente de um corpo, como, por exemplo em Paris (1972).

COMO ARTISTA MULHER, EU GOSTARIA
DE ENTENDER MINHA NATUREZA FEMI-
NINA E MINHA NATUREZA MASCULINA.
EM PARIS HOUVE UMA ESPÉCIE DE DUE-
TO DE AMOR COM PING CHONG, E NÓS
ESTÁVAMOS TENTANDO IR PARA A BOR-
DA DA NATUREZA MASCULINA E FEMI-
NINA. NÓS ÉRAMOS UM COMPOSTO DE
HOMEM E MULHER. EU TINHA UMA SAIA
LONGA E MEU CABELO ESTAVA EM UMA
TRANÇA, MAS EU USAVA BIGODE, UM
BONE DE COURO E GRANDES BOTAS DE
COMBATE. (MONK, 2014: P. 111) 36

Ao falar da voz em um amplo espectro me refiro à voz que transita entre vocalidades apresentando um amplo leque de texturas que percorre não só a extensão vocal com suas variaçôes espectrais, mas os seus vários tipos de corporeidade, uma voz inclassificável, não necessariamente pela sua erudição e virtuosismo, mas pela sua potência de transformação.
36 As a female understand my female nature and my male nature. In Paris there was a kind of love duet with Ping Chong, and we were very much trying to go to the edge of male and female nature. of male and female. 1 had a long skirt and my hair was in a braid, but I wore a moustache and a leather cap and big combat boots. (MONK in MARRANCA, 2014: $p$. 
$\operatorname{Key}(1971)^{37}$

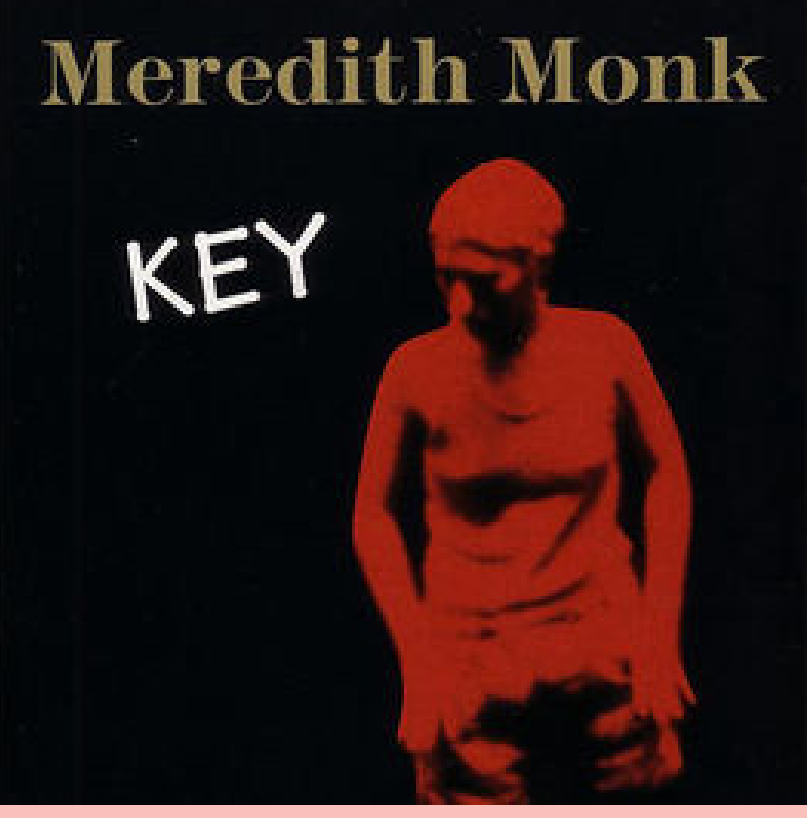

Lovely Music, Ltd.

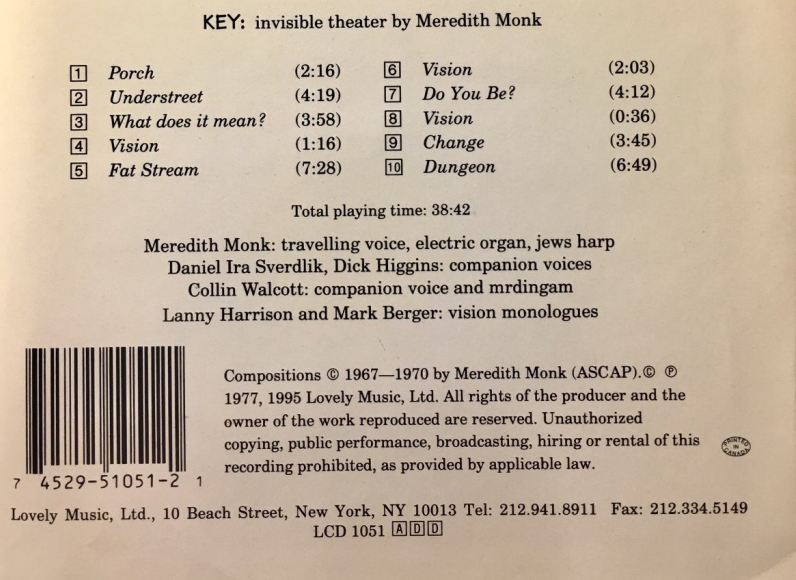

Capa e contracapa do álbum Key (1971), lançado novamente em 1995 em CD pela Lovely music, Ltd.
As composiçóes de Key foram realizadas entre 1967 e 1970 e o LP foi gravado ao vivo de julho de 1970 a janeiro de 1971 em Santa Monica, California; em The Ace Gallery, Los Angeles, California e em The House, Nova York. Key foi produzido por Collin Walcott, produtor também de Our lady of late (1973). A edição em CD foi lançada em 1995 pela Lovely Music, Ltd. Há diferenças entre as datas de lançamento de Key encontradas na internet. Na página oficial de Meredith Monk aparece como o primeiro álbum, lançado em 1971. Na discografia do livro de Jowitt de Key há duas datas: 1970 e 1977 ao mencionar o álbum. E em alguns sites que vendem o LP original, o lançamento data do ano 1971 pela discográfica Increase Records e logo em 1977 pela discográfica Lovely Music.

Outros créditos:

Direção artística-Paul Gruwel

Design-Ariel Peeri

Engenheiro de som-Daniel Nagrin, John Horton, Peter Pilafian, Tom Clack

Produção executiva-Ron Jacobs

Mixagem-John Horton

Fotografia-Peter Moore

Existem poucos textos que se refiram especificamente a este trabalho fonográfico inicial de Monk. A maior parte das referências teóricas sobre a sua obra são entrevistas realizadas ao longo da carreira, resenhas críticas e artigos em jornais, e alguns trabalhos acadêmicos, porém especificamente sobre trabalhos posteriores (não necessariamente fonográficos) e notas de artista.
37 INÉS: A segun foi dedicado a Collin Key Walcott, percussionista e produtor desse disco e de Our Lady of Late (1973). Walcott mor-

re com 39 anos num acidente de carro numa turnè do seu grupo Oregon na Alemanha. Lanny em Key, companheira de Walcott na época, trabalha com Monk até os dias de hoje. E respondeu um formulário por mim enviado, em janeiro
Nesse momento inicial (em que Key foi gravado e lançado), a artista se apresenta principalmente em galerias, realizando concertos solo de órgão elétrico e voz e peças site - specific. Se trata de um momento de imersão através do qual Monk intensifica a investigação sobre o seu repertório vocal na busca pela criação de um vocabulário de vocalidades para a composiçāo. Nas palavras da artista:
EXPLOREI DIFERENTES MANEIRAS DE MODUZR SOM, VARIASRESSONANCIAS, MODOS DE USAR A RESPIRAÇAO, LABIOS, BOCHECHAS E DIAFRAGMA. TAMBEM TRABALHEI COM OS EXTREMOS DA MINHA EXTENSAO VOCAL E MUDANÇAS RÁPIDAS ENTRE QUALIDADES VOCAIS PARA QUE A VOZ PUDESSE SER UM 
CONDUTOR FLEXIVEL PARA A ENERGIA

E OS IMPULSOS QUE COMECCARAM EMERGIR. EU COMPUS ALGUMAS CANCÕES A CAPELLA DURANTE OS AANCS SEGUINTES (INCLUINDO "PORCH", "CHANG" "DUNGEON"), E DEPOIS "CHANGE" SENTI QUE QUERIA TRABALHAR COM UMA BASE PARA VOZ. (MONK, 1995)

Muitas vezes seu trabalho é associado ao minimalismo, no entanto, Monk explica que nunca pensou na voz como um instrumento repetitivo, mas que ela cria a partir da instrumentação, um contexto para a voz viajar. $\mathrm{O}$ uso de repetiçôes ${ }^{39}$ na instrumentação de Key se justifica, segundo Monk, pela instauração de um tapete textural para a exploração vocal. Segundo a artista "o uso da repetiçáo é mais no sentido que se vê na música folk” (GARCIA LOPES, 1996) Se a música de Monk possui alguma influência do minimalismo, essa percepção se fundamenta na continuidad das bases harmônicas, com pedais sustentados no órgáo elétrico ao longo de algumas peças (como em What does it mean, Fatstream e Do you Be) em que a voz explora diferentes sonoridades, se entrelaça nas harmonias, mas sempre tem um lugar de destaque o escutar as camadas da totalidade da peça e o seu desenvolvimento.

A estrutura rítmica é fundamental neste trabalho, mas sempre em função da exploração vocal. Nesse contexto, a exploração da voz é fundada na repetição desse tapete textural que ao mesmo tempo apresenta o desafio de perceber a diferença gradativa e sutil da composição da mesma. O que nesses primeiros trabalhos surge como vocalidade mais experimental, logo fará parte de um extenso repertório vocal escolhido por Monk para a realização das suas peças e óperas. Esta fase de descobert das vozes é a fase que definirá o resto das camadas da sua obra, já que tudo começa pelas vozes.
$38 \quad$ lexplored difsound, various resonances, ways of using the breath, lips, cheeks and diaphragm. I also worked with the extremes of my range and quick changes from one so that my voice could be a flexible conduit for the energy and impulses that began to emerge. I composed a number of a cappella songs during (inclyding "Porch", "Chang" then felt that I wanted to work with a keyboard instrument as a ground base under my voice. (MONK, notas do álbum Key (CD), 1995)

39 INÉS: Outros trabalhos de artistas apresentavam este tipo de abordagem, como as ras Pauline Oliveiros e Joan La Barbara, Sound Patterns for chorus (1961) e The voice is the original instrument (1976), trabalhos que também utilizam padrōes de repetição em funçăo da

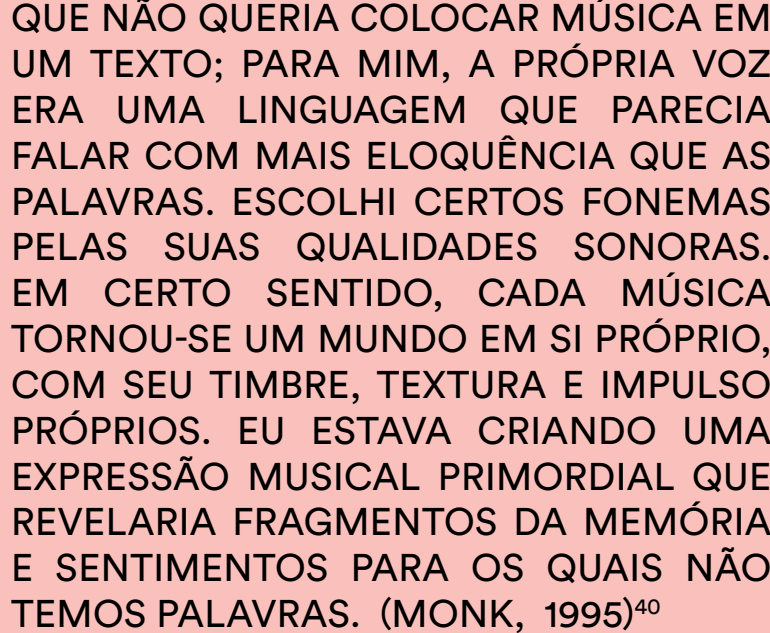

TEMOS PALAVRAS. (MONK, 1995) ${ }^{40}$

Em Key há passos sobre diferentes superfícies que se aproximam e se afastam e texturas instrumentais que formam uma unidade ao longo do disco e possibilitam os desdobramentos das vozes. São exploradas vozes na solidão e em companhia do órgão elétrico e do instrumento de percussão mrdingam. Assim como as sonoridades das vozes mudam, são apresentados diferentes timbres de órgão elétrico para a criação dos ostinatos, muitas vezes variando ao longo da peça junto com as vozes. No entanto, as harmonias escolhidas insistem sobre a mesma ideia em cada uma das peças. Os fonemas são explorados a partir dos seus possíveis desdobramentos e suas nuances discursivas. As palavras aparecem em narrativas de sonhos, procurando fidelidade
$40 \quad \ln K e y$ I wanted song deal with a diferente vocal character, landscape, tchnical concern or emotional quality. I was trying for a visceral, kinetic song form that had the abstract qualities of a painting dind't want to set music to a text; for me, the voice itself was a language which seemed to speak more eloquently than words. I chose certain phonemes for their particular sound qualities. In me a world in tiself with its own timbre, texture and impulse. I was tryin for a primordial musical utterance which uncove shards of memory and feelings that we don ' $t$ have words for. (MONK, notas do álbum Key, to create a constantly 


\section{Teatro Invisível, Espacialidade e Continuidade}

O MEU TRABALHO NÃO É TÃO PICTÓRICO, NO SENTIDO DE UM QUADRO OU DE UMA IMAGEM. É MAIS ESCULTURAL. (MONK, 2014: P.95)

A ideia de teatro invisível se associa às diferentes escutas de espaço ao longo do disco e às diferentes vozes apresentadas como personas e/ou personagens. Apesar de se tratar de um álbum que compila diversas peças compostas por Monk em situaçôes diferentes, as peças são como movimentos ou cenas interligadas pelas vozes que se apresentam, com variaçôes sutis, pelas paisagens e passos, pelas entradas e saídas das vozes, pelas repetiçôes de algumas qualidades vocais, e pelas intençôes similares do órgão elétrico, a partir das quais as vozes emergem. O álbum foi gravado ao vivo, vozes e instrumentos simultaneamente, captando também as ambiências dos espaços das gravaçōes.

\section{ENQUANTO TRABALHAVA EM KEY COMECEI A PENSAR EM COMO ESSE TRABALHO FICARIA COMO UM TODO. EU TENTEI CRIAR UMA SINTAXE E UMA CONTINUIDADE QUE UTILIZASSE AS QUALIDADES PARTICULARES DO MEIO DE GRAVAÇÃO. NÃO ESTAVA INTERESSADA NO ÁLBUM COMO UMA COLECÃO DE CANÇÕES, MAS COMO UMA EXPERIENNCIA MUSICAL COMPLETA. $(\mathrm{MONK}, 1995)^{42}$}

Desta maneira, pode-se entender que o disco Key é constituído por cenas e personagens; trajetos das vozes por espaços diferentes. São corpos vocais que se constituem e diluem principalmente sem apresentar palavras, mas evidenciando a presença das personagens a partir das possibilidades do som

Tendo em vista que as palavras são elas mesma representaçōes de coisas (emoçôes, açôes, objetos etc.), a criaçăo de sentidos (e não significados) em cena através da materialidade sonora do corpo vocal (que não está apenas a serviço da linguagem/representação) pode expandir as possibilidades de interpretação da obra pela audiência. Essa é uma ação
$42 \quad$ No original: started thinking of how all the material wouId go together. I tried to make a syntax and continuity that utilized the particular qualities of the recording medium the album just being collection of songs but rather a complete musical experience. I thought of it as "invisible theater" because the music seemed to come out of and go into darkness transforming from one "character" to another, going from one space to another, travelling from one level of intensity to another. (MONK, notas do álbum Key, 1995) que cria dissonâncias, instabilidades, espaços "entre" o que é irreconhecível e a invenção dx artista. (JACOBS, 2015: p.106)

Este entendimento da voz no teatro, não centrada no texto dramático (a partir do significado das palavras) está presente nos trabalhos de diretores e teóricos do teatro europeus do século XX, principalmente na poética do francês Antonin Artaud (1896-1948), grande influência filosófica para artistas do século XX e XXI.
43 No original: The first scream may be caused by pain, by the need for food, by frustration and anxiety, but the mothe moment it assumes the place of its addresse, the moment the other is provoked and interpellated by it, the moment it responds to it, scream retroactively turns into appeal, it is interpreted, it is transformed into speech addressed to the other, it assumes the firs function of speech: to address the other and elicit an answer. (DOLAR,
2006: p.27)

\begin{abstract}
A voz, no ideal de Artaud, estaria disposta a gerar múltiplos sentidos em cena, diferentes instância de um processo comunicacional que não primaria apenas pelo discurso articulado da linguagem/texto, mas que procuraria atingir o inconsciente da audiência através de seus sentidos: uma voz que se tornaria corpo para chegar a outros corpos. (JACOBS, 2015: p.107)
\end{abstract}

Artaud propôe um teatro ritualístico voltado para o encantamento da materialidade das vozes, onde as palavras são também fenômenos sonoros em movimento. Ao considerar que a representação pertence ao sistema da linguagem, e que a mesma está presente na percepção e recepção de quem assiste ou presencia uma performance, ainda, na investigação de vocalidades para além das palavras, há uma certa sujeição à linguagem verbal por parte de quem assiste. A intenção de quem performa pode trazer corporeidades outras, pode estar entremeada em açóes não vinculadas aos papéis sociais, e/ou priorizar o universo sensorial, porém a partir do momento em que essa ação é percebida, ela pode ser interpretada também como representação. Mladen Dolar se aproxima dessa discussão em seu artigo 'A linguística da voz" (2006), onde discorre sobre a transformaçáo do grito da criança em apelo, no pensamento de Lacan (de um grito puro a um grito para alguém).

O primeiro grito pode ser causado pela dor, pela necessidade de comida, por frustraçāo e ansiedade, mas no momento em que o outro o ouve, no momento em que assume o lugar de seu destinatário, no momento em que o outro é provocado e interpelado por ele, momento em que responde, grita retroativamente, transforma-se em apelo, é interpretado, dotado de significado, transforma-se em discurso dirigido a outro, assume a primeira funçá da fal dirigido ao outro, assume a primcira funçấo da fala: 2006: p.27) ${ }^{43}$ 
Desejo frisar aqui que mesmo se tratando de vocalizaçôes onde não há palavras, a memória e a experiência de quem escuta e percebe sempre se encontra condicionada pelo sistema de representação da linguagem verbal. Ao mesmo tempo, vocalidades como a tosse ou respiraçóes explícitas carregam significados. Há sempre alguma coisa sendo dita porque é dessa maneira que compreendemos o mundo, e pelo fato das vozes se encontrarem sempre em direção a alguém, mesmo quando esse alguém não foi determinado ou parece estar ausente. Entretanto, as emissōes vocais/não palavras expandem o leque de possibilidades de interpretação, deixando-o mais flexível, diminuindo o controle sobre a potência receptiva e sensibilizando outros aspectos da recepçáo.

No âmbito do teatro, a alternância entre tipos de vocalidades é frequente, entendendo que as vozes encarnam corpos/personagens de comportamentos inusitados, nem sempre corpos ligados aos papéis sociais, porém quase sempre vinculados à ideia de representação. Nesse contexto, a discussão sobre representação é frequente, ao mesmo tempo cada vez mais ambígua, considerando que a intenção e a percepçấo se encontram em contínuos tensionamentos e considerando o entendimento da noçáo de performance em diferentes contextos.

$$
\begin{aligned}
& \text { No Ocidente, damos um foco muito grande para a } \\
& \text { intencionalidade. Certo, isso acontece, pois preten- } \\
& \text { demos algo, mas temos que entender que os outros } \\
& \text { vão receber isso que realizamos com a melhor das in- } \\
& \text { tençóes de maneira diferente. Posso transmitir, mas } \\
& \text { o resto não é possível. E temos que entender isso. } \\
& \text { (FISCHER LICHTE, 2013: p. 3) }
\end{aligned}
$$

Segundo Zumthor (2014) o conceito de performance se refere sempre a alguma ação sendo percebida. "A palavra significa a presença concreta de participantes implicados nesse ato de maneira imediata" (ZUMTHOR, 2014) Para a pesquisadora de teoria teatral Erika Fischer Lichte, a consciência da ação sendo percebida é sempre teatral. É importante destacar que em alemão não há diferença entre o conceito de teatro e de performance. Em inglês, quando se fala em teatro, pensa-se em
dramaturgia; enquanto na Alemanha, falamos em
teatro quando há performances, sejam elas provin-
das da dramaturgia, do teatro não dramático, da
dança ou ópera etc. (FISCHER LICHTE, 2013: p.

Judith Butler (2006) entende que a identidade é produzida por meio dos nossos atos performativos ${ }^{44}$, evidenciando que a mesma não é algo inato e que esta é
44 INÉS: A noção presente no trabalho de John. L Austin em "How To do Things with Words"(1962) elaborada tanto a partir da fala como a partir dos significados do corpo que "excedem as intençôes do sujeito." (BUTLER, 2006) Para Fischer Lichte, o teatral é sempre performativo. No entanto, o performativo nem sempre é teatral, já que na perspectiva da pesquisadora o performativo não é sempre percebido. "Para mim, todo mundo é performer; o ator é sempre um performer, mas não todo performer é um ator."(FISCHER LICHTE, 2013)

quando estou lendo um livro e certas emoçōes sur-
gem, há um impacto em mim e ninguém percebe -
isso é performativo, mas não é teatral. Assim sendo,
eles se entrelaçam frequentemente, mas têm signifi-
cados diferentes. Mas teatral é sempre performativo.
(FISCHER LICHTE, 2013: p. 2)

Segundo Fischer Lichte, uma vez que há um público sempre haverá um papel. Em entrevista com o pesquisador Matteo Bonfito, a autora dá o exemplo de artistas da performance art que se machucam durante uma performance. Para a pesquisadora elas "estáo fazendo o papel de quem se machuca."(FISCHER LICHTE, 2013) No entanto, o papel de quem se machuca durante uma performance não é um "faz de conta”, mas uma experiência do próprio corpo que após aquela ação não será o mesmo. Fischer acrescenta que, no século XXI performers também trabalham com personagens e estórias, e atores fazem uso de ferramentas e abordagens que inicialmente eram parte da estética da performance art.

Meredith Monk não tem a intenção de definir o que as personagens em Key representam ou de contextualizar o lugar da paisagem sonora, evidenciando a fonte dos sons que aparecem durante a obra, constituindo, desta maneira, uma narrativa específica e/ou única. Em Key há várias histórias possíveis, e para cada voz, várias interpretaçôes possíveis.

A ideia de tela que vai sendo preenchida pelas diferentes técnicas (traços e cores) é recorrente nos depoimentos de Monk. A artista expressa que trabalha principalmente com o líquido da obra e logo define a garrafa (estrutura).

MEU TRABALHO É COMO LÍQUIDO COLORIDO; CONTINUA MUDANDO. ÀS VEZES É BRANCO PURO, ÀS VEZES LAMACENTO. PRINCIPALMENTE É ANÔNIMO E MUDA DE TAMANHO. ÀS VEZES CONGELA EM UMA FORMA POR UM CERTO TEMPO E ESPAÇO; ENTÃO TEM UM NOME: É CHAMADO DE PEÇA. É DESPEJADO EM UM DETERMINADO RECIPIENTE ESPACIALE CONGELA NESSA FORMA. ENTÃO, CIAL E CONGELA NESSA FORMA. ENTAOO, QUANDO ISSO TERMINA, ELE SE VAPO- 
VOLTA PARA O LIQUIDO E FLUI E NOVAMENTE. A MAIORIA DAS PESSOAS PENSA APENAS NOS RECIPIENTES, NOS NOMES,

NOS NOMES CERTOS, NA

REPETIBILIDA-

DE, NA OBJETIVIDADE. (MONK, 1997: P.

$30)^{45}$

O que é o líquido para Meredith Monk é algo complexo já que se trata de uma artista que procura uma espécie obra total no seu trabalho, onde a voz é entendida como mais uma articulaçáo do corpo e os objetos e espaços são constantemente ressignificados. Considerando que a maior parte das suas peças Monk surgem de ideias vocais, talvez o líquido seja a relação e a tensão que a artista reconhece entre as vozes a medida que a composição é realizada, a transformação da materialidade das vozes, sem definir uma estrutura prévia. Entretanto, o líquido pode-se referir também às vivências da artista como mulher de origem judaica, budista, compositora; vivências que tornam-se sonoras quando se tornam voz.

Escutamos as vozes enquanto ocorrem/tocam no disco, mas elas possuem uma certa leveza que se refere ao corpo que produz essas vozes. Parte do corpo vocal foi capturado na gravação, outra parte perdeu-se.

\begin{abstract}
A mediatizaçáo atenua ou apaga certos aspectos corporais da performance, aqueles que se referem à "tatilidade", mas ela deixa subsistir um traço essencial; o jogo, na transmissão da mensagem, de essíncial; o jogo, na tansmissáo da mensagem, de estímulos 2005: p.142)
\end{abstract}

Há um vazio nas vozes acusmáticas. São graus de performatividade; na voz gravada perde-se a presença do corpo. A presença que é presença por ser também movimento e não se refere necessariamente à presença visual desse corpo, mas as vozes ressoando em um determinado espaço, ao hálito, ao som acústico determinado pelo espaço e por outras fisicalidades. A questão das vozes acusmáticas não aparece unicamente a partir do desenvolvimento das mídias (rádio, gramofone, gravador, telefone), mas já se encontra presente na mitologia grega, também na literatura e no cinema.

O mito de Ovídio mostra o processo de uma ninfa "dotada de um talento retórico" (CAVARERO, 2011) que é condenada a repetir as palavras dos outros, "se torna uma ninfa vocal que rebate sons" (CAVARERO, 2011). Ao ser rejeitada por Narciso, Eco perde a sua materialidade, seu hálito, sua boca e pele, sendo reduzida a uma voz, ainda a voz da repetição.
Percebemos a presença do som vocal e da paisagem sonora apresentada em Key, mas o registro foi feito, mixado. Se trata de um teatro já interpretado, gravado, editado, perpétuo. Um teatro da repetição, em que o que se diz, já foi dito, e a presença e reação de quem escuta não terá nenhum poder sobre essas vozes, a não ser o de recriar Key em cada reprodução. Esse processo de escuta e recriação é um processo performativo, na medida em que altera o estado físico e emocional, na medida em que se trata de uma ação a partir do que é escutado.

PENSANDO EM TODAS AS MINHAS
PEÇAS COMO ARTISTA VISUAL, UMA DAS
MINHAS PRIMEIRAS ABORDAGENS É QUE
UMA VEZ QUE EU TENHO A CONFIGU-
RAÇÃO ESPACIAL, EU TENHO A ESTRUTU-
RA DA PEÇA. (MONK, 2014: P.87)

Entender o espaço para Monk é uma preocupação referida à preparação de uma performance no palco ou em outros espaços, mas também é pensar de que maneira as vozes ressoam, como elas convivem e se fundem em relação com outros instrumentos e com a arquitetura, também quando se trata de uma gravação. Considerando que a artista começa os seus processos a partir das vozes, muitas vezes em contraponto, pode-se pensar que o lugar que cada voz ocupa, no espaço e na harmonia, definirá a estrutura da peça. Segundo Monk:

\section{EU ACHO QUE EXISTE UMA MANEIRA DE \\ ESTRUTURAR QUALQUER MÍDIA COM O \\ CONCEITO DE CAMADAS - CAMADAS \\ TRANSPARÊNCIAS. (AT \& T, 1998: P.68) ${ }^{47}$}

Os espaços acústicos trazem a noção de camadas de acontecimentos, assim
45 My work is like is pure White sometimes muddy. Mostly it is nameless and it changes sizes. Sometimes it freezes into a shape for a certain time and space; then it has freezes into that shape. Then when that is over, gas, then back to liquid ITT, 1997: p. 30) colored liquid; it keeps name: it is called a piece. spatial container and it vaporizes, turns into and flows on and again.
46 Thinking of all my pieces as a visual
artist, one of my first approaches is that once I've got the spatial configuration, I've got the structure of the piece. MONK in MARRANCA 2014: p.87)

47 I think there is a way of structuring any ing and transparencies. (AT\&T, 1998: p.68)

48 INEÉS: https:// www.youtube.com/ cept of layering - layer como sucede nas suas performances, onde a artista trabalha com diferentes planos simultâneos de movimento dos corpos e vozes. O público (ouvinte) escolhe em que camada focar a atenção; em que voz e movimento reparar. Ao escutar mais de uma vez temos diferentes percepções que podem ser conduzidas intencionalmente ou não, já que cada vez escutamos de um modo, dependendo das circunstâncias, da intenção e do estado físico/emocional.

São camadas de ressonância, como em Songs of Ascension ${ }^{48}$ (2011), onde as performers se deslocam numa torre construída pela artista Ann Hamilton, por uma escada em espiral. Durante a peça as performers dançam, tocam shruti box, cordas, 
percussão, e cantam, percorrendo a torre em um roteiro idealizado por Meredith Monk.

O modo em que a concepção espacial de Monk é traduzida na gravação de Key (LP) depende das possibilidades técnicas da época (1970) e de um imaginário sensível que emerge das vivências e das memórias da artista.

$$
\begin{aligned}
& \text { Com o advento da gravação estereofônica, que pro- } \\
& \text { porciona uma forma de escuta que se aproxima mais } \\
& \text { à escuta binaural de nossos ouvidos (MENEZES, } \\
& \text { 1998), observa-se uma ampliaçãa na utilizaçáo do } \\
& \text { espaço sonoro uma vez que a reproduçáo dos sons } \\
& \text { ocorre em canais independentes. (BORGES, 2014: } \\
& \text { p. 3) }
\end{aligned}
$$

Em seu artigo "Elementos composicionais da espacialidade sonora" (2014), o pesquisador Alvaro Borges discorre sobre a organização do espaço na música eletroacústica ${ }^{49}$. Borges recorre ao trabalho de Francis Dhomont, para quem a especulação composicional do espaço sonoro acontece por três preocupaçôes mais básicas: "o figurativo, o simbólico e o artificial” (DHOMONT, 1998). O espaço figurativo apresenta o primeiro propósito de espacialidade, de que maneira as vozes são captadas, em que local? Com que tecnologia? O espaço simbólico se refere ao espaço imaginário, que procura captar a espacialidade de algum local. O espaço artificial é o espaço simulado, criado no estúdio, por meio da manipulação psicoacústica e da mixagem.

Embora a obra de Monk não seja pensada como música acusmática, é importante ressaltar que o sistema de reprodução estereofônico e multicanal emerge da tentativa de aproximar a escuta da gravaçáo às percepçôes durante uma performance, no que se refere à espacialidade e à tridimensionalidade do corpo/som no espaço. Entretanto, é evidente que se Monk apresentasse Key hoje em um concerto, as vozes soariam totalmente diferentes em relaçáo à espacialidade sugerida no disco. Ao mesmo tempo, a gravaçâo seria também outra, dado às mudanças e recursos tecnológicos do século XXI. O disco é uma obra e a performance é outra. No disco foi possível acrescentar diferentes tipos de reverberação, gravar as ambiências de diferentes paisagens onde emergem instrumentos e vozes, trabalhar as intensidades, a estereofonia e os aparecimentos das vozes, entre outros recursos.

\section{Procedimentos para a exploração Vocal}

Em Key há alguns procedimentos que se repetem ao longo do álbum. Organizei as peças segundo estes modos de compor a partir da exploração vocal. Procurei manter nos títulos dos modos as descriçôes dadas pela mesma artista nas Notas sobre a voz ou no encarte do disco. No caso das "Visões", o procedimento e o título das peças verbais presentes no álbum são o mesmo. No segundo capítulo me baseio nesses procedimentos e nas Notas sobre a Voz para refletir sobre as músicas em Key.

$50 \quad 1975$, solo for (Songs from the Hill), voice a reflection, a mirror" (MONK in JOWITT, 2014: p. 56) Originally published in Painted Bride Quarterly 3, no.2 51 INÉS: Utili-
zo o termo registro aqui para explicitar as
mudanças no processo fonatório que modificam a qualidade do som, variaçoes que partem de açōes da musculatura intrínseca da laringe. a sua pesquisa sobre a gogia da voz, a pesquisadora Joana Mariz diz: Segundo MCKINNEY (1994), nenhum outro termo da pedagogia vocal é mais envolto em confusão semântica do que o termo "registro". Ele pode dizer respeito a uma determinada região da extensão vocal (como quando se fala em registro agudo, médio ou grave), a ressonância processo fonatorio certo timbre ou ainda a uma região da voz que é delimitada por quebras abruptas na qualidade vocal. Embora a registração esteja em maior ou menor nivel relacionada com todos estes tópicos, tros vocais passou a ser visto pela pedagogia vocal de maneira mais objetiva e pontual depois dos aportes das ciências da voz." (MARIZ, 2013: p.52)
1 - Solo para voz desacompanhada ${ }^{50}$ - Escolha de uma escala e/ou de um tipo de emissâo vocal e suas nuances pela variaçấo de registros ${ }^{51}$ explorados.

2 - Paisagem vocal - contraponto de vozes cujas sonoridades se transformam ao longo da peça, apresentando diferentes vocalidades, mantendo em cada uma das vozes o mesmo motivo melódico ou notas pedais. Gravação de diferentes camadas que por sua vez apresentam diferentes espaços acústicos no disco.

3 - Visöes - Imagens acústicas dos sonhos em discursos verbais solos ou grupais (simultâneos).

4 - Trabalhando com um companheiro - Vozes viajantes sobre um tapete textural:

\section{a) Ostinato com pausas súbitas}

b) Ostinato com variação de acentos, de motivos melódicos, de instrumentação e de tempo.

c) Pedal - acordes ligados, em um tempo lento com variaçóes harmônicas mínimas

d) Ostinato predominantemente rítmico de um tempo constante.

\section{Faixas e procedimentos relacionados:}

1. Porch

2. Change

3. Vision \#1, Vision \#2, Vision \#3

4. Understreet (b), What does it mean (a), Fatstream (c), Do you be (c), 
5. Dungeon (d)

Ordem das faixas em Key: ${ }^{52}$

1. Porch

2. Understreet

3. What does it mean?

4. Vision

5. Fatstream

6. Vision

7. Do you be

8. Vision

9. Change

10. Dungeon

\section{Categorias para as análises das vozes}

Como apresentado na introdução, contarei com o trabalho de duas autoras para auxiliar a análise de alguns aspectos materiais das vozes, como parte do capítulo II. Do trabalho da pesquisadora Regina Machado (2007) farei uso dos parâmetros no nível físico e técnico. A seguir:

\section{Nível Físico}

- Extensão

-Tessitura

-Timbre (ou qualidade vocal)
- Voz Clara
- Voz escura
- Voz Aberta
- Voz Fechada

- Registro

- Basal

- Modal

- Elevado

Nível Técnico

$$
\begin{aligned}
& 52 \quad \text { INÉS: Optei } \\
& \text { por não traduzirir onome } \\
& \text { das faixas já que os } \\
& \text { títulos foram conjugados } \\
& \text { poeticamente para a } \\
& \text { composição e não todos } \\
& \text { seguem uma estrutura } \\
& \text { gramatical convencional. } \\
& \text { Sendo assim poderia } \\
& \text { pensar numa tradução } \\
& \text { aproximada. No entan- } \\
& \text { to, considerando que o } \\
& \text { interesse de Monk pelas } \\
& \text { palavras é predominan- } \\
& \text { temente musical, a tra- } \\
& \text { duçãa mudaria absoluta- } \\
& \text { mente a sonoridade. Ao } \\
& \text { mesmo tempo considero } \\
& \text { que o significado desses } \\
& \text { nomes é sugerido ao } \\
& \text { longo da pesquisa por } \\
& \text { meio da reflexão sobre } \\
& \text { as peças. }
\end{aligned}
$$


A pesquisadora Joana Mariz (2013) apresenta um quadro que ilustra as diferentes partes do corpo mais diretamente envolvidas na fonação e suas funções.

O esquema mostra que a cada nível do sistema acústico corresponde um grupo de órgáos do aparelho fonador, com seus agentes mais importantes, e uma funçâo fisiologica específica. Assim, a respiraçâo desempenha o papel de geradora de energia para o sistema formado entre a fonte, isto é, a fonaçao, e o filtro, isto é, a articulação. (MARIZ, 2013: p. 42)

Função
(acústica)

\begin{tabular}{c|}
\hline $\begin{array}{c}\text { Compressor } \\
\text { (energia) }\end{array}$ \\
\hline
\end{tabular}

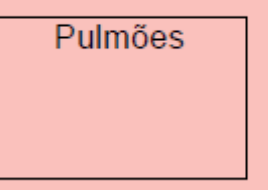
$\rightarrow$
pressão
subglótica Órgãos
responsáveis desempenhada (fisiologia)

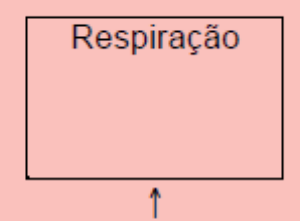

Músculos do abdômen e
diafragma
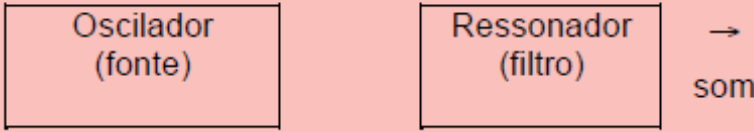

$\rightarrow$

Pregas Vocais

$\rightarrow$
fonte
glótica

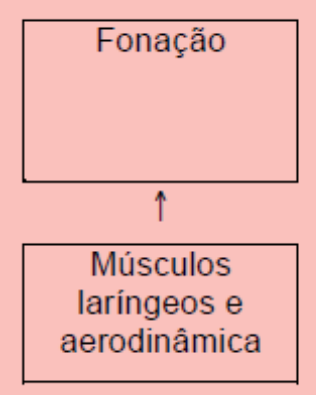

(MARIZ, 2013: p. 42)

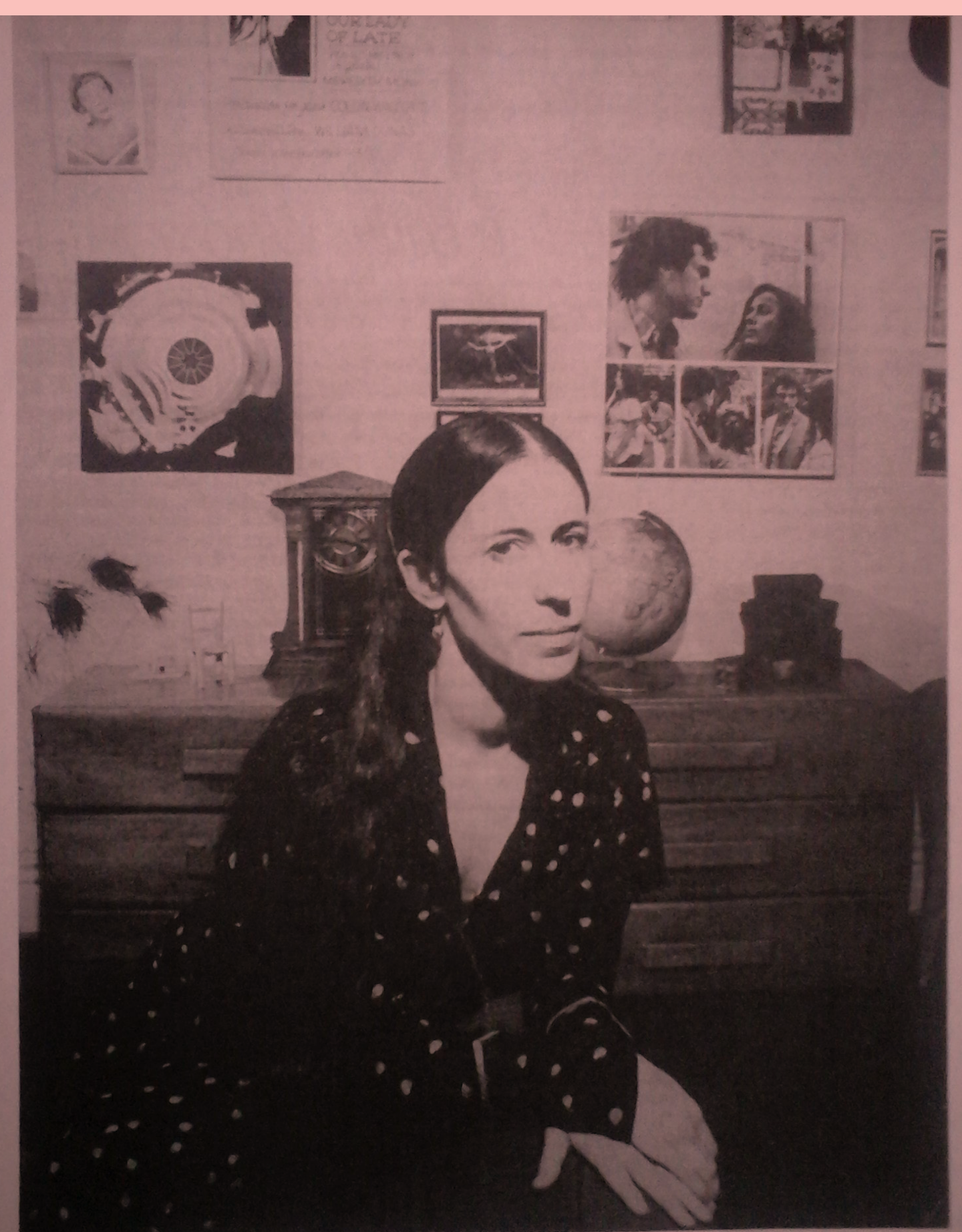

insma Dec. 1977

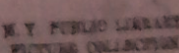


A VOZ COMO FERRAMENTA PARA DESCOBRIR,

ATIVAR, LEMBRAR, DESVELAR, DEMONSTRAR UMA CONSCIÊNCIA PRÉ-LÓGICA/PRIMORDIAL: PORCH

(FAIXA UM) (2:14)

\section{CAPÍTULO II}

\section{As Notas sobre}

a voz (1976) e Key (1971)

Solo para voz desacompanhada -1

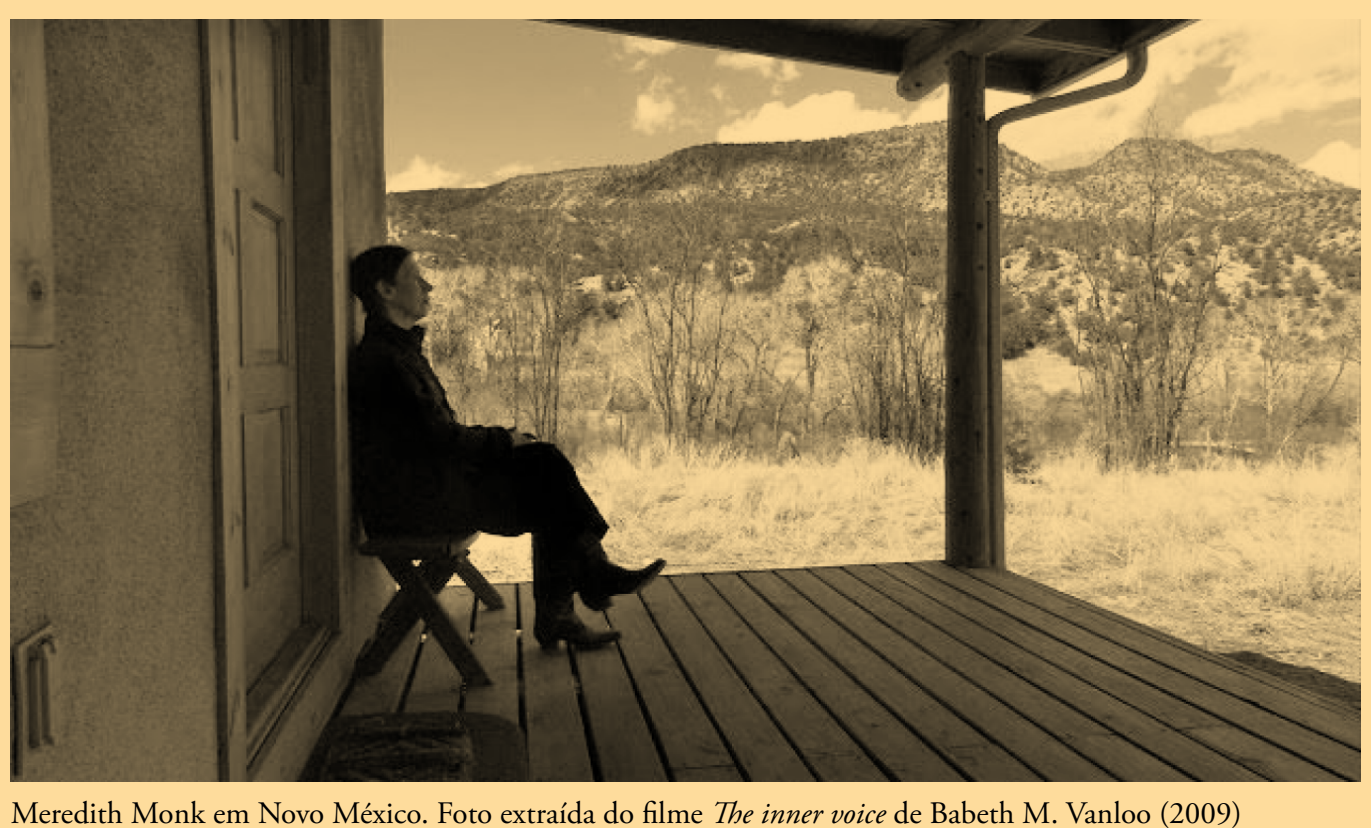

No dia dezesseis de dezembro de dois mil e dezessete assisti um pequeno concerto que Meredith Monk e algumas performers do seu ensemble (Jô Stewart, Ellen Fisher e

53 Em 1976, foi lançado o álbum com parte das seções que compõem "Songs from the hill" (MONK, 1989 [1979]). Este álbum traz Monk interpretando dez faixas. Entretanto, o programa de um recital (MONK, 1987) registra dez presentes no ́́los Breath song, que nunce foi gravada por Monk (ao menos não com este título) e Porch, gravada no primeiro álbum de Monk. (FALBO, 2014: Allison Sniffin) realizaram no Garrison Institute (Garrison, NY) como parte do retiro Voice as practice que Monk e Fisher estavam conduzindo esse mesmo fim de semana.

Porch foi a primeira música apresentada e também é a primeira música em Key. Segundo Monk, Porch é uma música de abertura, de concentração, uma música que a artista escolhe no começo de alguns dos seus concertos para iniciar a performance. Ao mesmo tempo, Porch é uma das poucas músicas de início de carreira que a artista preserva no seu repertório atual, apresentando a mesma por mais de trinta anos. Porch é também parte de um trabalho posterior chamado "Songs from the hill"s3.

A performance de Porch realizada no concerto em Garrison (NY, 2017) seguiu a estrutura do solo apresentado em Key (1971), porém a versão apresentou também 
outras sonoridades e articulaçôes rítmicas ${ }^{54}$ da voz diferentes às da gravaçấo. Nas duas versões o solo explora movimentos melódicos em uma escala pentatônica com uma voz clara, uma emissão frontal em um registro modal com nuances nos decaimentos de cada frase vocal. Na versão mais recente, o ruído vocal é menos destacado e as articulaçốes rítmicas são mais lentas. $\mathrm{O}$ solo tem uma curva dinâmica decrescente; as frases começam como chamados que vão se desdobrando num movimento mais interno.

Em Porch há uma continuidade na repetição das frases. Cada expiração é um trajeto similar ao anterior: os ataques e os decaimentos procuram lugares em comum com mudanças sutis e gradativas e com exploraçấo de diferentes vogais entre estes. $\mathrm{O}$ trânsito entre as vogais [u] e [i] nasais evidencia a manipulação dos harmônicos da voz.

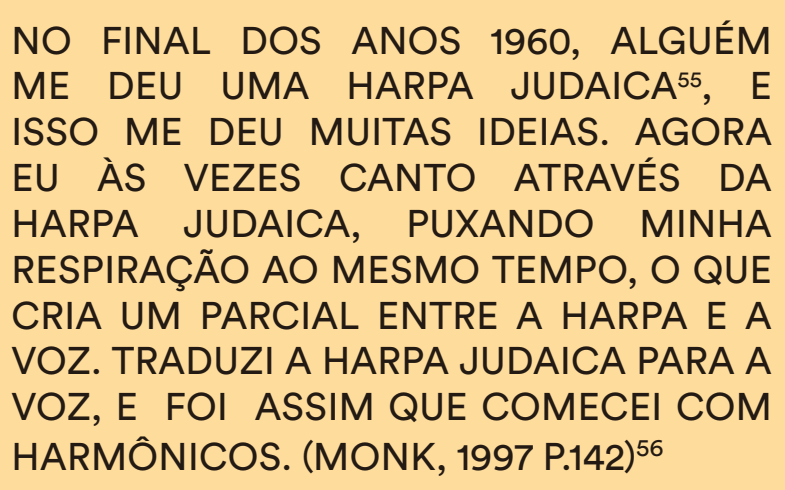

A nasalidade na transição entre [i] e [a] possibilita articulaçôes muito rápidas em Porch (do 0:03 a 0:05, e do 0:28 a 0:31). O tipo de emissão vocal frontal, assim como o uso da escala inicial de cinco tons, as quedas em micro-tons e as mudanças na qualidade do som nos finais de frase (decaimentos com drive e $f r y)^{57}$, se assemelham às sonoridades presentes no canto andino com $c a j a^{58}$ do noroeste argentino, cantos de paisagens montanhosas e áridas. Nesses cantos a voz cria trajetos a partir das paisagens e das distâncias, e das passagens da extensão vocal, ligadas à sociabilidade e à terra.

Monk entende que "o que procura fazer com a voz é bastante primordial, no sentido de tentar resgatar essa que é a forma mais essencial de enunciaçáo humana, e que vem antes das palavras"(GARCIA LOPES, 1996).
54 Articulação ríta cantora articula frases e periodos, a partir da percepção rítmic texto (letra), fundindo ou dissociando esses elementos, destacando ou minimizando a maneira como aparecem na composição. (MACHADO, 2007 p.59) INÉS: Ao se tratar de vocalizações culação rítmica como tros modos de subdividi e acentuar as frases vo cais, comparando a performance na gravação e a performance ao vivo

55 INÉSE: berimbau de boca. 1960 's someone gave me a Jew's harp, and that's given me a lot of sing through the Jew's harp, pulling my breath in at the same time, which creates a partial between the Jew's harp and the voice. I translated the Jew's harp to voice, and that's how (MONK in JOWITT:

p.142)

$57 \quad$ O vocal fry cor responde à região mais grave da extensão vocal, abrangendo uma faixa $75 \mathrm{hz}$. Fisiologicamente, é produzido com pouco fluxo de ar e atividade predominante do musculo TA, principalmente seu feixe externo (correspondendo ao que chamamos de fry do TA, juntamente com o CAL (Hirano, 1982), correspondendo ao que chamamos de fry de pulsos escassos, creaky voice ou fry tenso, com os demais músculos com atividade bastante reduzida. (PINHO, 1998: p.18) INEES: O fry pode ser aspirado ou produzido durante a expiração. a pressão do aré mais irregular e há mais possibilidades de atingir sonoridades polifônicas. mulheres são as grandes con caja. (VALLADARES, 2000: p.25) https://www. outube.com/watch?v= WnVZg55plU\&t=142s

59 It's the new ness and the oldness. newness is also cycling back to the ancient, like the cycle of time. The newness is totally fresh and would only happen in this moment, but at the same time there's some resonance toward it happening in 2018: p.59)

60 El del canto milenário y agreste. Su sustancia es el gritó y el riedades de la expresión vocal. Su estética es de lo abismal e infinito porque no busca la forma ni la belleza sino el desborde de la emoción. Su técnica es la imaginación voz, que puede alcanzar cualquier salto mortal que sirva para el dessangre psíquico. El canto académico, de orige europeo, regido por la impostación y la tersura, y por uma estética de la perfección. El del canto popular cuya estética es lo bonito y agradable y su técnica espontanea, natural y sin tensiones dramáticas. Canto pasatiempo. (VA)
E A NOVIDADE E O ANTIGO. ÀS VEZES SINTO QUE A NOVIDADE TAMBEM ESTÁ VOLTANDO AO PASSADO, COMO O CICLO DO TEMPO. A NOVIDADE É TOTALMENTE NOVA, ESÓ ACONTECERIA NETA TEMTO HÁ ALGUMA RESSONÂNCIA EM TEMACẼO A ISSO ACONTECENDO EM UM RELAÇAOO A ISSO ACONTECENDO EM UM PASSADO ANTIGO. (MONK, 2018: P.59)

No livro "Cantando las raices" (2000), sobre o canto andino com caja, a pesquisadora, filósofa e cantora Leda Valladares reconhece diferentes estratos percorridos pelo canto ao longo da história, cujos canais são três:

- O canto milenar e agreste. A sua substância é o grito e o guizo, com as mais variadas expressóes vocais sua estética é do abisma infinito porque não procura forma nem a beleza señ́o o estoro da proç-

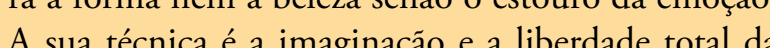

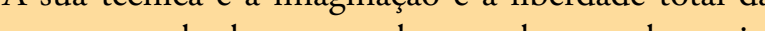
voz, que pode alcançar qualquer pulo mortal que sirva para o dessangre psíquico.

- O canto acadêmico, de origem europeu, regido pela impostaçáo e pela suavidade, e por uma estética da harmonia, a beleza e a perfeição.

- O canto popular cuja estética é o bonito e agradável e sua técnica espontânea, natural e sem tensōes dramáticas. (VALLADARES, 2000: p.7)

Valladares procura enfatizar a diferença entre os cantos de origem indígena e a canção popular e erudita (de origem europeia). É evidente que essas categorias não se encontram táo abruptamente separadas entre si no que se refere ao uso da voz, porém Valladares faz uma crítica ao estudo da voz a partir de uma relevância puramente técnica distante da emoção e a partir das demandas da indústria e do mercado musical no que se refere ao tipo de sonoridade vocal. É importante contrapor à distinçáo de Valladares, que a dramaticidade é sempre inerente à voz por estar absolutamente ligada à experiência do corpo. A autora chama a atençáo para o uso limitado da voz em contextos urbanos em comparaçấo com as vocalidades rurais, embora seja evidente, segundo a pesquisadora, que a música urbana foi e é influenciada por estas. Segundo Valladares os cantos são nus (milenar e agreste) ou disfarçados (acadêmico e popular): 
Os primeiros (milenares e agrestes) cantam o ser e expelem a melodia, trituram a voz e desesperam a linha melódica, e os segundos (acadêmicos e populares) cantam a melodia e mostram o brilho da voz.

(VALLADARES, 2000: p.15)

Valladares destaca as abordagens vocais andinas em contraposição a um único tipo de emissão legitimado, e a relevância da impostaçẫo da voz no caso do canto "acadêmico" em detrimento de vocalidades que percorrem as possibilidades da voz a partir da expressão das emoçôes, evidenciando quebras e quedas. Ao longo do livro, a pesquisadora explica a diversidade de interpretaçóes (quanto à melodia e à emissão vocal, inclusive à letra) que possui, por exemplo, uma baguala de uma mesma regiáo, apontando para a importância da unicidade da voz das cantoras, entendendo a unicidade no seu aspecto material e vivencial.

Ao refletir sobre o conceito de impostaçáo vocal percebo que esta acontece tanto no canto "acadêmico", no canto "milenar", e/ou na própria fala. No processo de aquisição das línguas passamos por uma adequação técnica aguçada, a partir da qual somos capazes de repetir as mesmas palavras e sons pelo aprendizado de determinadas qualidades materiais das vozes. Toda emissão é apreendida a partir de conjuntos de padrôes referentes às línguas ou idiomas musicais. Portanto, toda emissão poderia ser considerada um tipo de "impostação da voz". Entendo por idiomas musicais, territórios estilísticos com características sociais, harmônicas, rítmicas e melódicas específicas, assim como também no que se refere ao uso da voz, com suas inflexóes e variaçōes no tipo de emissão vocal.

Se por um lado, a busca por um vocabulário próprio e por uma voz que vai além da ideia de beleza herdada da música de concerto europeia faz parte da pesquisa vocal de Meredith Monk, a estrutura musical que ela estabelece é um elemento muito presente nas suas peças, assim como a forma canção (mesmo quando as palavras se ausentam). Por outro lado, Porch se aproxima do primeiro percurso do canto (milenar) sobre o qual Valladares discorre, considerando o tipo de sonoridade vocal e a abertura à paisagem que Monk documenta na cronologia de descobertas ao final das Notas sobre a voz nas músicas do disco "Songs from the hill":

1975, SOLO PARA VOZ DESACOMPANHADA (SONGS FROM THE HILL), A VOZ COMO REFLEXO, ESPELHO, RECEPTORA DA NATUREZA; VOZES DE ANIMAIS, PLANTAS, INSETOS; SINAIS, CHAMADOS HIEROGLIFOS; UMA OFERENDA A NATUREZA; A VOZ, TOTALMENTE SOZINHA,
$61 \quad$ Los desnudos cantan el ser $y$ expulsan tos cantan la melodia y RES, 2000: p.15)
DESACOMPANHADA, SEM ORNAMEN-
TOS (MONK IN JOWITT, P.57) $)^{62}$
Em Porch a voz desacompanhada é uma oferenda e ao mesmo tempo espelha uma paisagem. Os ornamentos se encontram nas articulaçóes da própria voz, na exploração de fonemas nasais e nas transiçōes entre as vogais. A voz desacompanhada ao mesmo tempo se entrelaça com a paisagem, sendo ela parte desta e ao mesmo tempo estrangeira, receptora de um silêncio desconhecido. Não há imitação, mas uma abertura para desestabilizar a própria voz.

Entendendo que a partir de uma investigaçáo do corpo explora-se o vocabulário vocal que não necessariamente se encontra vinculado ao estudo de um tipo específico de música, mas é comum à potência da voz, Monk diz:

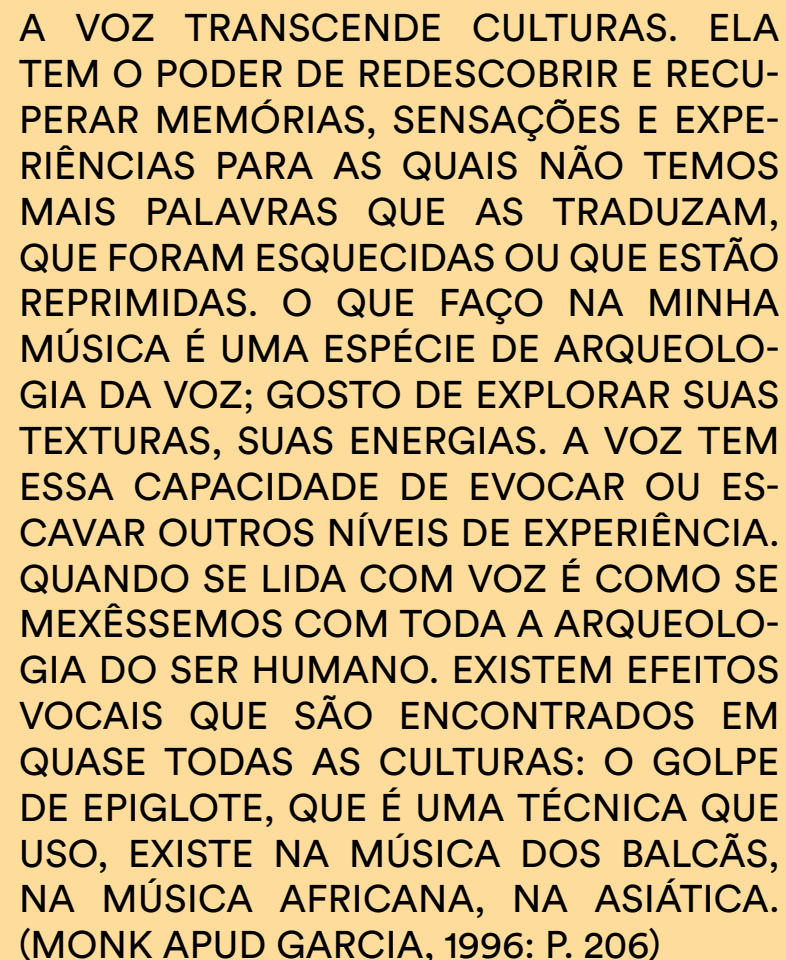

Monk entende que as técnicas vocais são inúmeras e que é possível chegar a estas de diferentes modos, nem sempre mediante contato direto com músicas ou vocalidades específicas, mas também a partir da investigação da própria voz que evidencia um eu ligado à ancestralidade das vozes. Desta maneira, talvez a voz não 
da voz em todas elas. Monk procura realizar uma arqueologia da voz, entender a voz como forma arquetípica, ligada para nós ao sentimento de sociabilidade.

O que Meredith Monk chama de consciência pre-lógica ou primordial se relaciona com a experiência inicial do corpo vocal. Há na vivência das vozes, memórias e sensaçôes não lógicas e/ou não lineares, referentes à primeira escuta, ainda não pautada na dialética dos discursos verbais.

O modo linear de pensamento sobre o tempo e a estrutura náo é satisfatório porque...náo reflete o modo em que nossas mentes trabalham. Estou muito interessada em fazer algo que tenha integridade em termos do modo em que a mente funciona. (MONK apud SCHLOSS, 1993: p. 17)

Se o $\operatorname{logos}^{64}$ é entendido no âmbito da filosofia ocidental como um código a partir do qual se entrelaçam as palavras produzindo semânticas verbais (como discurso e/ou como racionalidade), a voz em si nos conecta com o que Cavarero apresenta como signo (semeion). Ao discorrer sobre a emissão da voz humana e a dos outros animais, a autora aponta:

\begin{abstract}
Na Política, Aristóteles é muito claro sobre a questão. Ele aponta que só no homem a voz significa, ou seja é semantiké Nos animais da é signo (semeion) da dor e do prazer, é grito ou lameng. A voz an da plava da palavra - ou independente da palavra é simplesmente voz animal: fonação alógica, uma vez que as semântica, e, todavia, mesmo no animal, já semeion (CAVARERO, 2011: p. 51)
\end{abstract}

A voz humana é falante e gritante. Como tal ela é também signo do prazer e do lamento. Na voz humana a palavra e o grito convivem em tensionamentos constantes. Cavarero reflete sobre a desvocalização do logos, entendendo que a escuta da voz é esquecida no âmbito da filosofia platônica. Segundo a autora herdamos o mundo extremamente visual dos gregos. ${ }^{65} \mathrm{O}$ logos é, neste contexto, "um logos abstrato, anônimo: um código, um sistema" (CAVARERO, 2011), anulando qualquer tipo de unicidade e relacionalidade:

O preço da eliminação do caráter físico da voz é, em primeiro lugar, a eliminação do outro, ou melhor dos outros. Preanunciado pela metafísica platônica, o diálogo silencioso da alma consigo mesma não é somente um monólogo; é um solilóquio que, mesmo metaforizando-se na esfera da voz, neutraliza o
63 The linear way and structure is not satisfying because...it does not reflect the way that our minds work. I'm very interested in doing something that has integrity in terms of the way that the mind works. (MONK in

$64 \quad$ Logos deriva do verbo legein. Desde Grécia arcaica, este verbo significa tanto "falar" quanto recolher, "ligar", 2011: p. 50)

grego com termos como nomea ou idéa, o que nós chamamos significado é, de fato, para a do pensamento caracterizado pela visibilidade, clareza, evidência. Não se trata apenas da relação entre plano do pensamento e plano da palavra, e tampouco da conviçãa, também tipicamente metafisica, de sobre a palavra. Tratase, bem mais, do gesto fundamental que coloca o princípio do sistema de significação, o significado, na esfera visual. (CAVARERO, 2011: p. 53) hebranto na tradiça da verdade à a escuta, esclarece Hanna Arendt, a tradição metafísica de matriz grega entende a verdade em termos de metáfora visual. (CAVA-
RERO, 2011: p. 53) estatuto relacional da voz e, portanto, da palavra. A alma, tal como acaba sugerindo Platáo, pode desconsiderar a phoné corpórea e se contentar com a metafórica. Do flósofo grego em diante a lma metafica. Do flósofogrego se diante a alma fala

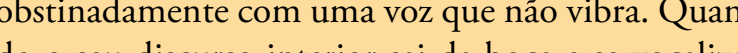
do o seu discurso incrior sai da boca e se vocaliza, ela passa a ajustar as contas com uma interlocuçáo verbal que atrapalha a perfeição insonora e descorporizada do colóquio solipsístico. (CAVARERO 2011: p. 205)

A ontologia vocálica sobre a qual Cavarero discorre, considera a unicidade do ser. Segundo a autora, esta ontologia opóe-se às ontologias filosóficas que nomeiam o "homem", o "sujeito" e o "indivíduo", denominaçôes que não consideram as particularidades de uma voz. "A filósofa baseia seu argumento na relacionalidade da voz, e na compreensão de $\log _{0}{ }^{66}$ como ligação ou religaçăo, do grego legein." (JACOBS, 2015)

Em Monk a voz é um modo de entender o mundo e de atravessá-lo a partir das vozes que soam junto. Ao mesmo tempo, a artista reconhece também nas vozes a unicidade, dando como exemplo, vocalidades que são produzidas por uma performer durante o ensaio e que ela não consegue reproduzir, e vice - versa. Na exploração vocal descobre-se esta unicidade, a partir de fisicalidades e experiências diferentes; diferentes vozes, diferentes escutas. Sobre a questão da unicidade Cavarero também aponta:
66 Por mais que definição unívoca, 0 logos alude ao plano né Semantiké. Mesmo reduzida a significante fônico, a voz parece ancorar o logos em um horizonte onde existem bocas e ouvidos, mais do que olhos e olhares. da palavra e abrange a fonação. Não por acaso,
Basta refletir sobre um caso frequente, reiterado e até engraçado da nossa vida cotidiana. Alguém atende o telefone ou pelo interfone, me pergunta: 'Quem é?', 'Quem fala?'. E eu respondo, sem hesitação: 'Sou eu'. A funçáo despersonalizante do pronome eu - aqui acentuada pelo fato de que quem fala náo mostra seu rosto - é assim imediatamente anulad pela unicidade inconfundível da voz. O som vence a generalidade do pronome. A cena engraçada do cotidiano, versáo banal da história de Isaac, demon tra que cada ser humano tem na unicidade da voz uma auto - revelaçáo sonora que transpóe o registro linguístico da significaçáo. (CAVARERO, 2011: p. 205) 
É importante mencionar que quantas mais vozes sejam exploradas mais dificilmente este eu é reconhecível, apesar da sua unicidade. As vozes da voz revelam uma multiplicidade de "eus", portas de vaivém abertas à entrada e saída de um outro. O eu é também outros na voz relacional que experimenta e transita entre as suas possibilidades. No entanto, a unicidade é definida por uma fisicalidade, uma escuta e uma história específica, resultando em sonoridades próprias de uma corporeidade irrepetível.

\section{TRABALHANDO COM UM COMPANHEIRO: WHAT DOES IT MEAN?}

\section{(FAIXA TRÊS) 3:58'}

Ostinato com pausas súbitas $-4^{\mathrm{a}}$.

$67 \quad$ No original: had studied piano as highschool I had written a few short piano pieces and had learned guitar to accompany myself as a folk singer. From my folk singing days, I remembered the pleasured of an instrument being a kind of carpet for the voice to from. I chose an electric organ rather than a piano because I liked the sustained tones, the particular timbres created by the various stops, and inherent sense of its sound (MONK, nin its sound. (Món álbum Key, 1995) acterizar as diferença entre espaços e tempos lisos ou estriados, Boulez usará a palavra superfiproposta por Bouleza respeito das operações que constituem o tempo liso e o tempo estriado, ele sintetiza: "no tempo liso, ocupa-se o temp sem contá-lo; no tempo estriado, conta-se (BOULEZ apud BONAFÉ, 2016: p. 107). Ele dirá que uma superfície lisa é aquela na qual não possivel determinar nem uma velocidade nem um sentido para os acontecimentos, pois "o olho referência à qual se prender" (BOULEZ, 1963, 100). Já numa superfície estriada, regular ou irregular, a velocidade e o sentido dos eventos se impoem. (BOULEZ apud

\begin{abstract}
EU TINHA ESTUDADO PIANO QUANDO ÉGIO EU TINHAESCRITO ALGUMAS PECAS CURTAS DE PIANO E APRENDI VIOLÃO PARA ME ACOMPANHAR COMO CANTORA FOLK. DOS MEUS DIAS DE CANTO FOLK, EU ME LEMBRAVA DO PRAZER DE UM INSTRUMENTO SER UM TIPO DE TAPETE PARA A VOZ SE MISTURAR OU SALTAR A PARTIR DO MESMO. ESCOLH O ÓRGÃO ELÉTRICO EM VEZ DE UM PIANO PORQUE GOSTAVA DOS TONS SUSTENTADOS, DOS TIMBRES ESPECÍFICOS CRIADOS PELAS VÁRIAS PARADAS E DO SENSO INERENTE DE ESPACCO E ESCALA EM SEU SOM. $\left(\right.$ MONK, 1995) ${ }^{67}$
\end{abstract}

What does it mean? É uma pergunta sem resposta, ou uma pergunta sendo respondida por mais uma pergunta. São vozes que evocam imagens que ainda são esboços. Entre o harmônico e o ruidoso, entre o tempo estriado do órgão elétrico e de uma voz estridente e insistente, e o tempo liso da voz grave em queda com uma emissão ruidosa ${ }^{68}$. Uma voz que empurra o sistema nervoso para fora do corpo, na necessidade de existir sobre um grave continuo que não abandona o corpo. Duas vozes convivem e se contrapóem, elas são a mesma, porém cada uma tem seu espaço.

O órgão elétrico desenvolve uma introdução (0:00 a 0:24), apresentando uma textura harmônica e rítmica repetitiva, até estabelecer um ostinato em que a voz entra para a experimentação. Este tempo não é fixo, variando ao longo da peça, e apresentando pausas súbitas. Há variaçôes de timbre no órgão elétrico. Estas acontecem a medida que as vozes também mudam. Monk entende o acompanhamento das vozes como tapetes texturais. Pode-se pensar esse acompanhamento também como fundo e suas vozes como duas figuras contrastantes.

Em Emotion and Meaning in Music, Leonard Meyer, fundamentando-se na teoria da Gestalt, descreve textura como "... as maneiras com que a mente agrupa estímulos musicais concorrentes em figuras 
simultâneas, uma figura e um acompanhamento (fundo), e assim por diante (MEYER apud NETO,

2007: p.185)

Há nessa percepção uma hierarquização de espaços realizada durante a escuta. Essa hierarquizaçâo pode mudar ao longo da peça a partir da escuta no tempo. A medida que a peça transcorre, o que parecia ser uma figura pode se tornar fundo e vice - versa. Figura e fundo são conceitos ambíguos em algumas composiçôes e/ou contextos, apresentando-se como conceitos dinâmicos. Em What does it mean? distinguese inicialmente o primeiro fenômeno, uma vez que quando a primeira emissáo vocal se estabelece, entende-se que o órgáo cumpre a função de acompanhamento, pela sua apresentaçáo inicial e repetição, e pelo seu lugar no espaço, com menos intensidade. Tanto o órgão quanto as vozes se encontram equilibradas na sua divisão estereofônica, porém a voz se encontra enquanto no convívio com o tapete textural em um plano frontal. No entanto, o que foi entendido como acompanhamento logo se instala como mais uma voz (figura, de 0:59 a 0:19) entre as exposiçóes vocais, apresentando também um protagonismo gestual, ainda como superfície estriada. Por outro lado, a segunda figura se apresenta como uma voz na ausência do acompanhamento inicial: como figura e fundo simultaneamente.

Em What Does it Mean? a experimentação da voz acontece em três exposiçôes. A primeira entrada da voz (0:25) se desenvolve na insistência do material vocal, chegando num pico (do grito e de agudos) na primeira frase. Em seguida, após a segunda exposição, o órgão se detém e a voz faz um glissando com uma emissão ruidosa, a partir do fry com variaçôes entre [a], [a] e $[\Lambda]$. No segundo "interlúdio" entre as exposiçóes, destaca-se um som eletrônico inharmonico (1:45 a 1:55), sugerindo a vozl fry que passa entre as primeiras duas exposiçôes, produzindo um processo de síntese. A partir do minuto 1:56 o fundo se expande ao acrescentar uma nova camada com um novo timbre e que complementa o ostinato inicial, com uma figuração que também oscila e alterna fórmulas de compasso.

A primeira voz se apresenta em uma regiáo modal e aguda, de emissão predominantemente frontal; uma voz que flutua entre uma espécie de glossolalia com os fonemas [m], [n], [s] e [z] e uma queda em glissando pelo fry nos finais de frase; uma voz na que predomina o uso de vogais fechadas. Monk não menciona o conceito de glossolalia nas suas entrevistas, porém entende essas vocalidades ou línguas inventadas também como criadoras de sentidos:

EU REALMENTE SINTO QUE ÀS VEZES ES-

SES FONEMAS E QUALIDADES VOCAIS

NÃO - VERBAIS FALAM MAIS ALTO QUE

PALAVRAS. ELES TAMBEM PODEM DELI-

NEAR, MAIS CLARAMENTE, EMOCOOES

\section{ENERGIAS PARA AS QUAIS NÃO TEMOS}

PALAVRAS.(MONK, 2018)

No artigo "No marulhar das glossolalias em Artaud"(2013), os pesquisadores Gil Roberto Almeida e César Lignelli investigam o conceito de glossolalia e o caracterizam como um termo em contínua transformação através da história:

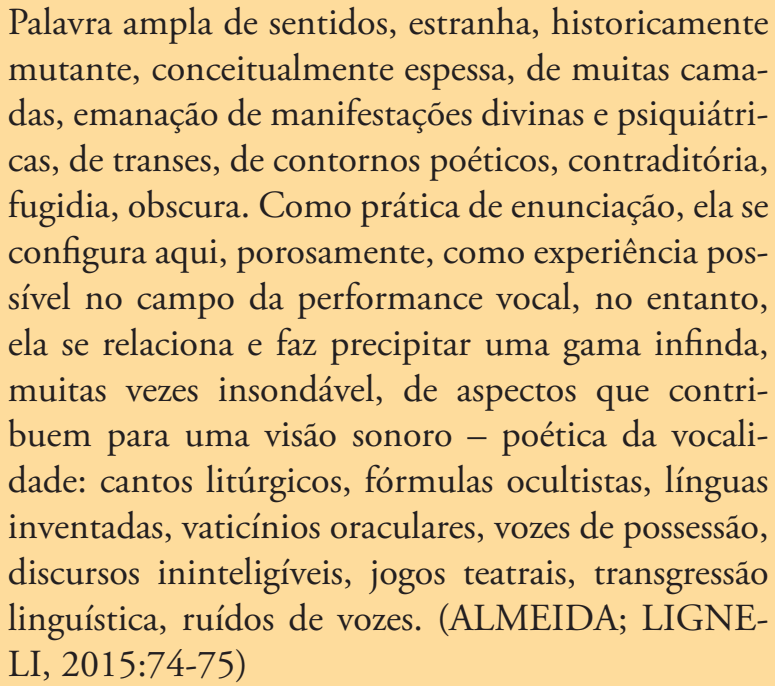

LI, 2015:74-75)

Ao indagar em uma perspectiva histórica do termo, os pesquisadores mencionam a glossolalia como constitutiva de rituais cristáos, na prática oral das igrejas pentecostais, como uma manifestação da voz de Deus. Entretanto, o termo é utilizado em diferentes âmbitos, sendo apropriado e entendido de diversos modos, quase sempre ligado à oralidade e a um dizer nômade, ou para além da linguagem verbal reconhecida:

a glossolalia não é um fenômeno religioso estritamente cristão, pois fazia parte de práticas pagăs, sobretudo em contextos marginais, como é o caso das práticas oraculares e outras liturgias na Gréci antiga. Ademais, é um termo que foi apropriado pela psiquiatria, pela psicanálise e pela linguística, para registros nosográficos de patologias psíquicas e distúrbios da linguagem. Em qualquer contexto relacionado à prática glossolálica, ela sempre se relacelacionado à pratica glossolica, ela sempre se relada vocalidade, seja do texto escrito, sempre como da vocalidade, seja do texto escrito, sempre como transbordamento e excesso de um código, norma ou
de uma estrutura. (ALMEIDA; LIGNELI, 2015:

$69 \quad$ I actually feel phonemes and nonverbal vocal qualities speak louder than words. They can also delineate, more clearly, emotions and energies for which we don't have words. (MONK, 2018) p.76)

Em alguns momentos, a voz insinua palavras nos finais de frase. Na segunda exposição se reconhece a frase She drives me crazy. As transiçóes vocais entre as expo- 
siçôes são imprevisíveis e carregam um tipo de tensão entre as partes, sendo que não se sabe qual será o desenvolvimento da exposição seguinte. A voz muda sem aviso. NO MEU TRABALHO HÁ UMA PEQUENA
LINHA ENTRE O DISCURSO/FALA E FO-
NEMAS PUROS. VOCÊ TEM A SENSAÇÃO
DE UMA VOZ FALANDO, MESMO AO SE
TRATAR DE UMA LINGUAGEM ABSTRATA. (MONK, 2014: P.105)

Apesar de preponderar um tipo de emissáo vocal, existe o contraste entre o que foi chamado de exposiçáo da voz mais aguda, frontal e rugosa, que constitui a glossolalia, e uma voz mais grave e agonizante, que corta o fluxo e nos prepara para um novo lamento sobre o tempo estriado. Como se tudo aquilo fosse um sonho, ou como se tudo surgisse na vigília, e o ruído da voz e do órgão participassem de uma queda, quebrando a insistência. $\mathrm{O}$ órgão acrescenta agudos com um timbre de sino em forma de pedal (2:20 a 3:38), insistente, na tentativa de aproximação com esse ser híbrido e vibrante, diminuindo a intensidade e a velocidade. No entanto, este fica ressoando sem a voz, até a voz rugosa voltar em um glissando, escorregando, quase sem força, e o sonho, ou a consciência insistente, acabar.

\section{A VOZ COMO LINHA DIRETA PARA AS EMOÇÕES. TODO O ESPEC- TRO DA EMOÇÃO. SENTIMENTOS PARA OS QUAIS NÃO TEMOS PALAVRAS: FAT STREAM (FAIXA CINCO, 7:28)}

Ostinato Pedal - acordes ligados, num tempo lento com variaçóes harmônicas mínimas $-4 \mathrm{c}$

Fat Stream se inicia com um arpegio maior ligado, num ritmo lento, junto com um pedal agudo na oitava acima do baixo inicial, estabelecendo a harmonia a partir da qual a voz emerge. A primeira emissão vocal (0:18) é coberta, com vibratos instáveis apoiados em melodias tonais e decaimentos micro-tonais (0:45), transitando por diferentes vogais. Esta primeira emissão talvez seja a mais próxima a uma emissão lírica. Apesar de Monk ter realizado práticas de ópera durante a sua formação, a artista afirma que seu principal desejo era descobrir o seu modo pessoal de usar a voz. Entender quais são as possibilidades no próprio corpo vocal, e não seguir um modelo único. Sendo assim, o treinamento clássico vira mais uma ferramenta, invés de uma regra. Ao descobrir o seu próprio repertório de vocalidades, Meredith Monk compõe a sua obra.

\section{AO LONGO DO TREINAMENTO VOCAL CLÁSSICO, SENTI QUE NUNCA TIVE O TEMPERAMENTO PARA DEDICAR MINHA VIDA A EXECUÇÃO DE REPERTÓRIO PA- DRÃO. SIMPLESMENTE NÃO PARECIA CERTO OU CONFORTÁVEL. ${ }^{70}$ (MONK, 1990: P. 1)}

Uma segunda emissão acentua o [i] frontal (1:00) como em um chamado repetitivo. Uma terceira voz evidencia variaçốes de movimento de lábios modificando os harmônicos nos finais de frase (1:33), logo com ataques mais fortes (1:50), com movimentos do palato mole, do fundo da garganta, e um grito com a vogal "a” em uma textura mais ruidosa (1:54), tensa e chorosa. Aos poucos volta para uma sonoridade mais lírica com vogais e glissandos ascendentes e descendentes (2:21) em baixa intensidade. São vogais fechadas; notas longas flutuando sobre o arpegio inicial. Volta ao [i] frontal ligado à voz inicial com vibratos, mais lamentos,...transita entre uma e outra, e ao mesmo tempo emergem novas possibilidades e variaçôes entre as vozes já apresentadas. A partir da segunda exposição das vozes (3:45), após uma breve reapresentação da introdução do órgão elétrico, algumas antecipaçôes das frases vocais que virão escutam-se de forma mais evidente, porém em uma baixa intensidade. $\mathrm{O}$ tapete textural é constante e as vozes flutuam sobre o mesmo. O movimento é contínuo, mas 
a emoção/emissão se transforma ou transita pelo espectro apontado por Monk.

Se a emoçáo possui um espectro, ele é particular e diferente em cada pessoa. Ao mesmo tempo, o espectro é dependente e interligado com outros espectros. Em seu livro "A voz articulada pelo coraçáo" (2013), a pesquisadora e atriz Meran Vargens distingue emoção de sentimento, destacando a primeira como volátil e passageira, e o último como "cultivado e duradouro". Ter palavras para os sentimentos é alimentá-los a partir da linguagem e do que recriamos como memória. Cultivar um sentimento é agir sobre ele. Há uma intencionalidade no que conhecemos como sentimento. Já as emoçōes parecem escapar do domínio da intenção, apesar de sermos conscientes das mesmas. "A emoçâo é uma usina atômica de energia" (VARGENS, 2013) "E emoçáo não é o mesmo que sentimento. Emoção real - não temos nem uma palavra para isso. Não é tolice, tristeza. É como tons sutis de sentimento ou energia." (MONK, 2014) Assumir que é inevitável transitar de um estado para o outro é mais importante para Monk do que escolher um tom emocional único predefinido. O que as vozes em Fat Stream devem expressar não se encontra escrito; é uma corrente, um fluxo de passagens sutis entre sonoridades aproximadas.

Em sua pesquisa sobre voz e emoção (2010), a pesquisadora Laura Beatriz Backes apresenta teóricos do teatro que procuram uma descoberta da voz a partir do desbloqueio das emoçōes, estabelecendo relaçôes entre processos da psicologia ${ }^{71}$ Freudiana e Junguiana em suas práticas. Para isto estuda as práticas de Wolfsohns, Roy Hart. Sobre Wolfsohn (Alemanha, 1896 - 1962), e ela diz:

As técnicas de Wolfsohn nasceram da descoberta de novas possibilidades da voz relacionadas a uma situaçáo de alto impacto emocional. Wolfsohn, aos 17 anos, participara da Primeira Guerra Mundial como maqueiro, transportando feridos do campo de batalha para os postos de enfermagem. Ao longo da guerra vivenciou sucessivas situaçóes perturbadora guerra vivenciou sucessivas situaçoes perturbadoras
ligadas aos gritos de agonia de seus companheiros. (BACKES, 2010: p. 23)

Após a guerra, Wolfsohn procura diferentes terapias e conclui que precisa realizar uma catarse a partir das vozes, entendendo que os seus traumas psicológicos se encontravam intimamente ligados às vivências do seu corpo durante a guerra.

Catarse é "o método terapêutico que permite a evocaçáo e a revivência de acontecimentos traumáticos que foram reprimidos, permitindo a descarga dos afetos ligados a estes." Já a ab-reaçáo seria a própria descarga emocional que libera estes afetos, tornando-os conscientes e aliviando os sintomas somáticos.
(CERQUEIRA LEITE apud BACKES, 2010: p. 23-24)

Wolfsohn procura recriar os gritos de guerra pelos quais tinha sido profundamente atravessado, mas que nesse momento estariam escondidos como marcas reprimidas no seu corpo, incapazes de sair a luz após o período de guerra. Ao não encontrar nenhum professor de canto que entendesse e aprovasse esse desafio, já que a maioria considerava o grito como prejudicial para a voz, Wolfsohn começa a experimentar suas ideias em si mesmo:

$$
\begin{aligned}
& \text { Ao longo das suas descobertas, com o que ele cha- } \\
& \text { mava de "exorcismo oral", ele descobriu uma exten- } \\
& \text { são inimaginável, percebendo que a sua voz pode- } \\
& \text { ria expressar inúmeras possibilidades de emoçôes, } \\
& \text { atmosferas e personagens. Ele poderia trazer para a } \\
& \text { voz, não só os tons agonizantes do sofrimento, como } \\
& \text { também a intensa alegria e prazer. A excitação com } \\
& \text { suas descobertas fizeram com que ele continuas- } \\
& \text { se a experimentar sua voz consigo mesmo durante } \\
& \text { muitos anos, conseguindo o táo esperado alívio das } \\
& \text { manifestaçôes físicas do seu sofrimento. (BACKES, } \\
& \text { 2010: p. 26) }
\end{aligned}
$$

O que começou como um processo de cura tornou-se potência para a imaginação e a experimentaçấo. É evidente que os dois processos convivem; os processos somáticos e os da criação, o enfrentamento das afliçôes e a produção de prazer. Percebe-se como a experimentação vocal abre espaços no cotidiano das pessoas, espaços que muitas vezes eram absolutamente negados e/ou desconhecidos. Nesse processo de escuta e de elaboração de si, o corpo vocal pode trazer experiências que foram esquecidas ou anuladas, assim como revelar algum aspecto da personalidade.
71 Considero, ainimportante a ser traçado com Reich, ainda que não haja uma influência direta nas pesquisas de Wolfsohn. A procura de Reich em esclarecer como se dá a repressão das emoções, relaciodo corpo e da voz com a liberação da pessoa é semelhante à proposiçãa de Wolfsohn, sintetizada numa frase de Roy Hart, "a pessoa é aquilo o que pode cantar". (BACKES,
2010: p. 22) 


\section{A VOZ COMO LINGUAGEM: VISÕES, VISION \#2 (FAIXA SEIS, 2:03)}

Cada língua possui um repertório de sons e seus modos de articulação. Podese dizer que cada língua possui uma sonoridade específica e para cada língua exploram-se diferentes qualidades materiais das vozes. Isto significa que, por exemplo, a nossa língua materna propicia um determinado conhecimento da voz no processo de aquisição da linguagem verbal. Ao mesmo tempo cada língua é constituída em um determinado território, onde há múltiplos sub-territórios, que determinam sotaques, e que são adquiridos a partir da experiência de cada corpo, manifestando também um sotaque próprio.

Em uma escuta das palavras para além do seu significado sugere-se um espaço onde todas as sonoridades se encontram, sejam elas elementos constitutivos das línguas ou não. Existe um sentido dos sons que a voz produz, construído a partir do contexto social e das especificidades do corpo vocal. No trabalho de Meredith Monk há vários exemplos, como em Quarry (1976) ${ }^{72}$. O performer Ping Chong, vestido de terno, com as mãos na cintura, interpreta o ditador. Chong cria um discurso de vocalidades ininteligíveis, gritadas, com um efeito de delay constante falando para uma grande plateia. Reconhece-se que Chong é o ditador pela entonação das palavras inventadas, pela sua postura e gestos ao vocalizar.

Ao escutar uma língua que desconhecemos, talvez o primeiro foco de atenção seja a sonoridade da mesma: Qual é a sua melodia, como são seus ruídos e quais são os resíduos da fala? Ao escutar uma língua que conhecemos ou mesmo a nossa primeira língua, falada por alguém que possui um sotaque novo para nós, inicialmente escutamos o sotaque e depois o que a pessoa disse (o significado). Mesmo quando náo se trata de uma voz que reconhecemos como diferente, de imediato captamos o hálito dessa voz, sua presença material.

Mesmo no nível mais banal da experiência diária quando ouvimos alguém falar, a princípio, podemo estar muito conscientes de sua voz e de suas qualidades, sua cor e sotaque, mas logo nos acomodamos nos concentramos apenas sobre o significado que transmitido. (DOLAR, 2006: p.15)
É um mecanismo onde o que primeiro reconhecemos é a diferença, pela história de uma voz, pela aquisição de uma língua ou, no caso de uma voz desconhecida, pelo estranhamento que gera a escuta de uma voz que não pertence ao reconhecido politicamente como o sotaque oficial. A diferença sempre possui relaçôes com o que é determinado como o hegemônico, priorizando um sotaque em detrimento de um segundo ou terceiro, qualificando-o como "o outro".

Nas denominadas "Visões" Monk pede para as performers explorarem as vozes a partir de relatos de sonhos no intuito de sugerir imagens. Segundo o autor Paul Zumthor (2014), "não se sonha a escrita, a linguagem sonhada é vocal". Durante os sonhos somos capturadas pelas vozes e pelas paisagens.

\section{A escrita se constitui numa língua segunda, os signos gráficos remetem, mais ou menos, indiretamente palavras vivas. A língua é mediatizada, levada pela voz. Mas a voz ultrapassa a língua; é mais ampla do que ela, mais rica. (ZUMTHOR, 2005: p. 63)}

Entre a língua escrita e a fala, toda língua possui uma distância, uma espécie de vácuo, no que se refere à escolha das palavras, às construçôes gramaticais utilizadas e ao modo de dizer, como se a língua resistisse à experiência de cada corpo. Por outro lado, "a leitura de um texto poético é a escuta de uma voz." (ZUMTHOR, 2014). Ao perceber que há graus de oralidade também na escrita, talvez o vácuo encontre-se no que concebemos como linguagem, em contraposição à oralidade. Segundo Cavarero:

$$
\begin{aligned}
& \text { A linguagem generaliza, universaliza, apaga as di- } \\
& \text { ferenças. Procede por semelhanças e abstraçóes, re- } \\
& \text { sumindo a multiplicidade das coisas a uma série de } \\
& \text { nomes, continuamente reiterados como o mesmo. } \\
& \text { (CAVARERO, 2011: p.68) }
\end{aligned}
$$

Se o sistema da linguagem universaliza a experiência ao dar um significado para cada palavra representando uma vivência ou um objeto (as vezes alguns significados possíveis, no caso das palavras e línguas polissêmicas) a voz tensiona essa definição a partir da unicidade do corpo e da experiência do mesmo. Uma mesma história contada por pessoas diferentes não é a mesma história, assim como a imagem das palavras "ruído", "terra" ou "fome" são imagens específicas em quem enuncia ou escuta essas palavras. Sendo assim, toda e cada voz algo diz, mesmo quando repetem-se as mesmas palavras, ou mesmo quando estas se ausentam.

$$
\begin{aligned}
& \text { Entendida como algo que sai da boca de alguém, a } \\
& \text { palavra, mais do que lugar de expressáo, é o ponto } \\
& \text { de tensão entre a unicidade da voz e o sistema da } \\
& \text { linguagem. (CAVARERO, 2011: p.30) }
\end{aligned}
$$

Mladen Dolar entende o ato de tossir e o soluço como quebras no discurso 
verbal, ao se tratar de reaçōes que interpreta como fisiológicas, não intencionais ou não "culturais", no sentido de não carregarem significados dentro da linguagem em si. Porém ele também discorre sobre a mensagem embutida nessas sonoridades que o autor chama de pre - simbólicas:

$$
\begin{aligned}
& \text { "Semiótica da tosse": tosse enquanto se prepara para } \\
& \text { falar, usa-se a tosse como comunicação fática de } \\
& \text { Jakobson, estabelecendo um canal de comunicação } \\
& \text { de comentários irônicos que póe em risco o sentido } \\
& \text { do enunciado; como uma notificaçãa da presençaa } \\
& \text { de alguém; como uma interrupção de um silêncio } \\
& \text { difícil; como parte da pragmática da comunicaçẫo } \\
& \text { telefônica. (DOLAR, 2006: p.24) }{ }^{74}
\end{aligned}
$$

Nesses casos o pre - simbólico adquire significado em oposição ao simbólico. No caso da risada, uma especificidade humana, pre - simbólica e simbólica, esta se coloca como uma expressão vocal em relaçáo com o discurso verbal, mas também possui uma independência do mesmo como sonoridade fisiológica. Tanto as vocalidades que Dolar (2006) chama de pre - simbólicas como as simbólicas, podem ser acionadas, sendo ressignificadas. Tanto as vozes fisiológicas como as simbólicas carregam as marcas de um corpo, e portanto, todas elas comunicam algo, mesmo quando sáo entendidas fora do domínio da linguagem.

Nas Visóes a tentativa de recriar as imagens acústicas dos sonhos sugere diversas interpretaçôes. Por um lado, escuto um texto em inglês, com diferentes sotaques, com palavras reconhecíveis, porém, assim como nos sonhos, elas não se encontram ligadas de maneira que seja necessariamente destacada uma narrativa linear, mas principalmente uma poética da lembrança do sonho, a partir da qual é difícil saber o que veio antes e depois, e de que maneira surgiram as imagens.

Desta forma, escuto vocalidades que procuram recriar rastros do inconsciente, definidas pela linguagem verbal, mas independentes desta pela sua plasticidade sonora e imagética. É importante destacar que ao ser o inglês uma segunda ou terceira língua no meu corpo, percebo às Visóes mais facilmente como fenômenos sonoros, mesmo ao entender o significado das palavras. Quando escutamos uma língua sobre a qual não temos total domínio, ao não realizar uma conexão imediata com a dimensão linguística do discurso, a percepção sonora predomina, percepção melódica, rítmica, de acentos e entonaçôes. "O fato de eu usar palavras de maneira abstrata é ainda uma ideia musical de texto em oposiçấo a uma ideia narrativa." (MONK, 2014) ${ }^{75}$

Apesar de Monk ter escolhido a presença das palavras para essas secçôes do

74 "semiotics of coughing": one coughs one uses coughing as Jakobson's phatic communication, establishing a channel for communication ironic commentary which jeopardizes the sense of the utteof one's presence; interruption of a difficult silence; as part of the pragmatics of telephone communication. (DOLAR, 2006: p.24)

75 The fact that use words abstractly is
still a musical idea of text as opposed to a narrative RANCA, 2014: p.105)

disco, que funcionam como contrastes entre as vocalidades exploradas no resto das faixas, a performatividade vocal dos sonhos evidencia as nuances sonoras das modulaçôes da língua, com diversos sotaques e entonaçōes, e sugere outras recepçôes da palavra, mais ligadas às imagens de um discurso poético e à flexibilidade das vozes, do que à palavra em si.

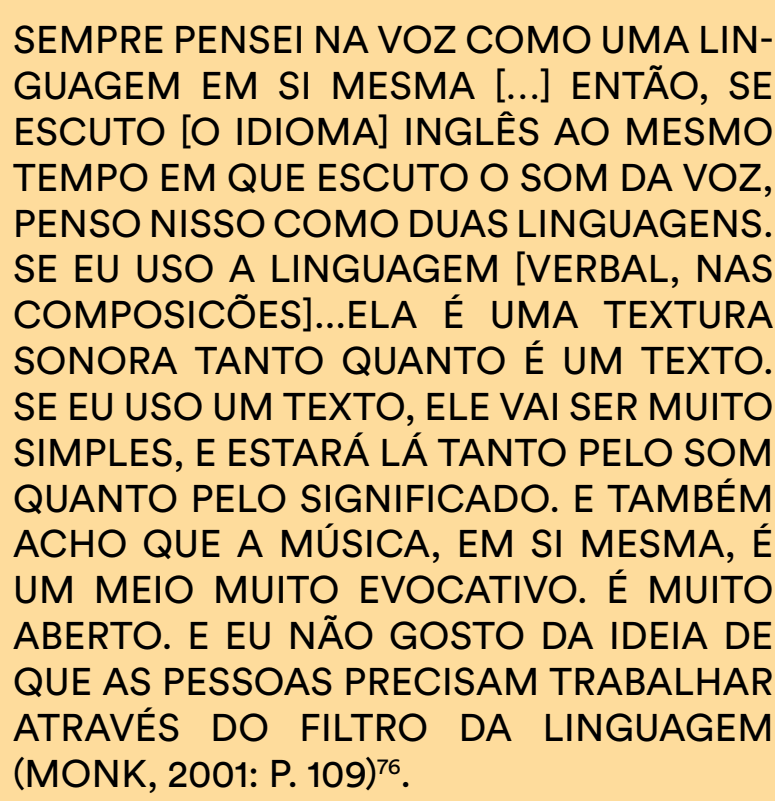

Na visão número 2 (faixa seis), criada por Lanny Harrison, a artista utiliza diferentes emissōes vocais, apresentando três personagens conversando entre si. Pode-se entender também como um monologo de oposiçôes, três personagens em uma; uma voz que se acelera gradativamente, em uma fala atropelada, com uma sonoridade na que predominam os harmônicos médios; uma voz coberta, com mais harmônicos graves, apoiada nas vogais, mastigando o som; e uma voz estridente que se apoia nas consoantes. As vozes ressoam em um espaço com bastante reverberação. Entre as vozes há um comentário da harpa de boca (0:29). Além da variação no tipo de emissão vocal, há variação na velocidade das frases, há repetiçấo de palavras com entonaçôes diferentes e explosōes vocais ininteligíveis. As acentuaçôes das palavras não se encontram necessariamente ligadas ao seu significado.

$$
\begin{aligned}
& \text { haveria muito a dizer sobre o valor concreto da } \\
& \text { entonação no teatro, sobre a faculdade que tem as } \\
& \text { palavras de criar, também elas, uma música segun- } \\
& \text { do o modo como são pronunciadas, independentes } \\
& \text { do seu sentido concreto, e que pode até ir contra } \\
& \text { esse sentido se criar sob a linguagem uma corrente } \\
& \text { subterrânea de impressōes, de correspondências, de } \\
& \text { analogias. (ARTAUD, 1999: p. 37) }
\end{aligned}
$$

76 Thave always a language in its voice, I think of it as two positions]... it is a sound a text. If I use a text, it it will be there for both sound and meaning. And itself, is a very evocative medium. It is very open. And I do not like the idea that people need to work through the language filter (MONK in KEY; ROTHE, 2001: p. 109,Traducão de Conrado Falbo). 
No monólogo são feitas descriçôes de um lugar ("pequeno quarto”, "com muitas paredes") e de diferentes apariçôes ("plantas", "criaturas", "fantasmas", "pássaros", "pequenos gatos", "um homem que veste uma camisa azul", "uma cabeça raspada") e açóes ("colocando coisas em suas bocas", "correndo ao redor", "sabia que eu devia conhecê-lo", "saiu fora do bolso"). Também há frases na primeira pessoa, anunciando a protagonista do sonho: "Fui ao fundo", "Estou muito ocupada agora". Ao perguntar sobre a participação de Lanny Harrison na Visão \#2, a artista responde: muitas vezes eu basearia os meus monólogos em um
sonho de uma noite antes de uma apresentaçáo. Os
sonhos me contaram como contar uma história, ou
me informaram sua forma, estilo, cor, pessoas, eras.
O sonho de Key é sobre meu marido Collin Walcott. (HARRISON, 2019)

$\mathrm{Na}$ cronologia de descobertas das Notas sobre a voz, Monk descreve Key como um disco de movimentos pelas paisagens de sonhos (moving through dream scapes). No livro "Meredith Monk" (editado por Deborah Jowitt) há textos de sonhos escritos por Monk. Para a artista os sonhos são referências em várias peças, assim como menciona Harrison. Se movendo entre paisagens de sonhos, os monólogos aparecem como um modo de levar a atenção para um outro lugar, apontando para outras narrativas.. Sobre a aparição e a ordem desses monólogos no disco, Harrison diz:

muitas vezes usamos monólogos para colorir ou au-

mentar ou fazer parceria com o movimento ou para

apontar para uma ação ou ser contida por uma. às

vezes as palavras eram muito escassas, ou, no meu

caso e no de Mark Berger, a história poderia desven-

dar e desvendar e ser surprer

dar e desvendar e ser surpreendents

Nos monólogos parecem ser alternados dois procedimentos, os dois influenciados entre si. Por um lado, a reconstruçáo dos sonhos das artistas através dos relatos. Por outro lado, a investigaçáo da ressonância das vozes no espaço, se desapegando das palavras que constituem a história, em um processo de repetiçáo das mesmas. Nesse processo de investigaçáo do eco das vozes, outras palavras emergem, palavras que não necessariamente foram consideradas inicialmente para o relato dos sonhos. De um modo e do outro, os sonhos se constituem como processos inconscientes que ao ser narrados perdem sua característica principal. Durante os sonhos há outros mundos possíveis, condensando realidades já vividas, inventando outras e iluminando os desejos mais recônditos; a linguagem sonhada se encontra vinculada às abordagens
$77 \quad$ Often I would based my monologues on a dream from the night before a performance. The dreams told me how to tell a story, or shape, style, color, people, eras. The dream on Key is about my husband Collin Walcott.

$78 \quad$ We often used monologues to color or heighten or partner with movement or to point to ned by one sometimes words were very sparse or, in my case and in Mark Berger's, The story was allowed to unravel and unravel and be surprising or sublimely artísticas, onde criam-se outras possibilidades de se relacionar, onde criam-se outras ordens, onde as regras são outras. 


\section{A VOZ COMO MANIFESTAÇÃO DO SELF, PERSONA OU PERSONAS DO YOU BE (FAIXA SETE, 4:12)}

Ao conceber o self como um fenômeno em devir, entende-se que a percepção de si e do mundo é continuamente reconfigurada. Desta maneira, as vozes são percebidas também como um fenômeno em movimento, sendo inventadas a cada momento. "A voz é uma construção a cada momento que se materializa, que se corporifica em formas de ondas sonoras" (VARGENS, 2013) Segundo o pesquisador Alexandre Socha, "embora a voz veicule uma determinada subjetividade, considerá-la expressão do self seria o mesmo que assumir o self como uma cápsula intrapsíquica definida e bem delimitada" (SOCHA, 2010). Nessa perspectiva, a voz seria mais uma experiência do self do que uma expressão, se apresentando como potência gestual e individual, porém sempre sendo travessada por outras vozes. Em Monk, entender a voz como um fenômeno em movimento se vincula a abertura da artista ao desconhecido Ao mesmo tempo, a compositora concebe a interdependência dos elementos que ela fricciona em uma mesma obra como uma analogia com a interdependência dos seres.

\section{A IDEIA DE DEIXAR TUDO PARA QUE ALGO REALMENTE NOVO POSSA PASSAR. A IN- TERDEPENDÊNCIA - EU SEMPRE TIVE A IDEIA DE TECER ELEMENTOS JUNTOS PERCEPTUALMENTE. É TAMBÉM UM RE- FLEXO DA IDEIA DE INTERDEPENDÊNCIA DA PERCEPÇÃO E DOS SERES. EU FIQUE MENOS COM MEDO DE ARTICULAR ISSO. \\ EU NÃO TERIA ARTICULADO QUANDO \\ EU ERA JOVEM, MAS ACHO QUE ESTA- \\ VA REALMENTE FAZENDO ISSO. (MONK, \\ 2014: P.50) ${ }^{79}$}

A música $D o$ You Be foi gravada e lançada em um disco pela primeira vez em Key (1971), mas é também parte da ópera épica Vessel (1971) sobre a história de Joana d'Arc e do disco Do You Be (1987). A artista Lanny Harrison sugere Do You Be quando peço para ela escolher alguma música em Key. Harrison comenta:

Amo escutar a música Do You Be da ópera Vessel. Sua voz navegava como um espírito desmembrado e co- rajoso pelo telhado do seu loft ou por todo o teatro, e eu, como a Dama Branca revelada em sua escad de incêndio, ou em uma subida em uma escada, me inspirava em sua voz, em sua mírica, no seu brilho
80 A love listening from Veredith's Do You Be sailed like a disembodied and brave spirit through the roof of her loft or throughout the theater. and I, as The White Lady revealed on her fire escape or on tour up on a ladder, took inspiration from sic, from que brilliance as conssumate criator/ performer

81 I made a decision at a certain point with my albums not to talk about the visual aspects of a piece that peobecause then they say "I wish I saw the whole piece." And I say, "Did you like the music? (MONK, 2017)

82 The organ in dregging at something it is partly a beat of meditation and partly a neat of submersion, but gainst these steady dredging meditation thumps is suddenly uncoiled the high-pitched, insistent They drive at the head in leaps: they spring at us in an astonishing, inhuman cross-breeding of the primordial and electronic. (SAINER in
MARRANCA, 2014: $p$.
Embora Do You Be seja parte do repertório da ópera Vessel, estreada no mesmo ano do LP em questão, é preciso escutá-la também no contexto do Teatro Invisível em Key, sem a ambição de tentar recriar a ópera de Monk, constatando que a música das vozes em Do You Be carrega o peso da história em Vessel. Entretanto, independentemente de sua montagem visual e da concepção da ópera, Do You Be existe como peça musical, possibilitando outras leituras e escutas. Nas palavras da artista:

\section{EU TOMEI UMA DECISÃO, EM CERTO PONTO COM MEUS ÁLBUNS DE NÃO FALAR SOBRE OS ASPECTOS VISUAIS DE UMA PEÇA QUE AS PESSOAS NÃO VÃO VER, PORQUE ENTÃO ELES DIZEM: - QUERIA TER VISTO A PEÇA INTEIRA. E EU DIGO: - VOCÊ GOSTOU DA MÚSICA? $(\mathrm{MONK}, 2017)^{81}$}

Em Key Do You Be começa com o ciclo de ataques e longos decaimentos de um som contínuo no órgão elétrico, um pedal, um fundo sem silêncios, uma sequência de acordes ligados que preenche o espaço, ao mesmo tempo deixando um grande vazio; um fundo grave que chama a açáo das vozes em regiôes agudas para estas serem ouvidas. A dramaturgia dos acordes mostra como o corpo vocal envelhece, como ele se faz matéria. É nomeado e logo some repentinamente, se ausenta, porque nomeá-lo é destruí-lo. O som da voz insiste sobre diferentes gritos e relaçôes com o fundo.

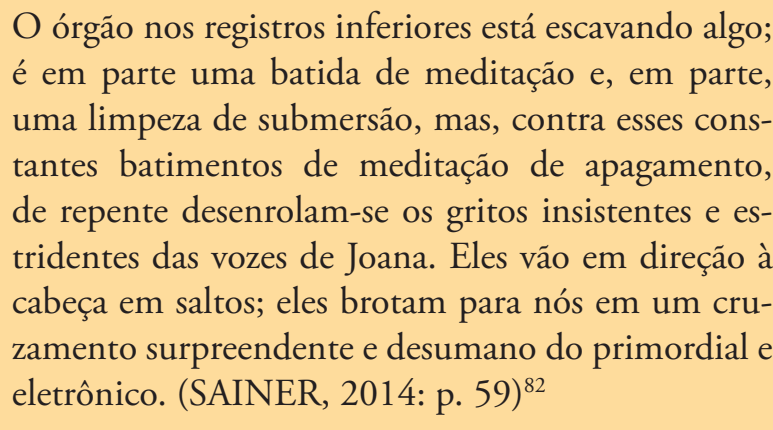

Quando o tempo do tapete textural sincopado parece se estabilizar, ele oscila mais uma vez para dizer: não há corpo que não flutue, não há corpo que não se perca na junção dos diferentes tempos internos, que são muitos, que fracassam 
para surpreender, para desvendar mais uma voz. Do You Be é um leque de duas cores principais com variaçôes de fonemas, de dinâmicas e de intensidade das vozes sobre o tapete textural ligado dos acordes. Monk apresenta diferentes modos de ulular em direção à regiáo mais aguda da voz (1:02), modos de desenhar com as formas do riso $^{83}$ (1:50), modos de glossolar, de desejar ficar (2:35), de pedir piedade (3:15), de dar mais uma oportunidade para a voz trazer diferença (3:29); são novos modos de ser Meredith Monk, novos modos de insistir sobre a ideia vocal inicial, em tensionamentos com o fundo.

PARA MIM, É MAIS COMO DE QUE MANEIRA ENCONTRO NOVAS VOZES EM MIM? COMO NÃO ME ACOMODO NOS MEUS ANTIGOS HÁBITOS? COMO DESCUBRO ALGO NOVO NA MINHA PRÓPRIA PERCEPÇÃO DO MUNDO? (MONK, AT\&T 1998$, P. 75$)^{84}$

Procurar novas vozes é permitir que novas personas sejam elaboradas e percebidas. É soar através do mesmo corpo, de modos diferentes, e possibilitar que outras vozes passem através, também de um modo intencional. O conceito de persona se encontra inicialmente associado às máscaras no teatro da Grécia antiga.

$$
\begin{aligned}
& \text { No antigo teatro grego, os atores usavam máscaras } \\
& \text { representando expressóes de felicidade ou pesar. As } \\
& \text { vozes do ator, com suas nuances e vibraçôes indivi- } \\
& \text { duais, podiam ser ouvidas atrás das coberturas rígi- } \\
& \text { das. O "som" da própria voz do ator dava um senso } \\
& \text { de indivíduo por trás do contorno firme da máscara. } \\
& \text { A palavra persona significa literalmente "soar atra- } \\
& \text { vés". Em uma sociedade que exige que certos papéis } \\
& \text { definidos sejam projetados para o mundo externo, a } \\
& \text { palavra persona também passou a significar o senso } \\
& \text { de identidade que escolhemos projetar. Cada um de } \\
& \text { nós têm inúmeras personas, algumas das quais pode- } \\
& \text { mos preferir manter ocultas. (STEINMAN, 1995: } \\
& \text { p. } 28-29)^{85}
\end{aligned}
$$

Segundo a pesquisadora Virgínia Moreira (1994), "máscara” é uma palavra que recebemos do árabe, e que no teatro grego representava tipos sociais e não indivíduos, evidenciando papéis sociais da polis, ao portar um simbolismo genérico, como uma categoria humana, uma classe social e/ou uma figura heroica."A palavra pessoa tem suas origens no verbo personare que quer dizer soar através de, cujas raízes estão no etrusco - phersu - que significa máscara teatral”.(MOREIRA, 1994).

No artigo "The Acoustical Mask of Greek Tragedy" (2007), os pesquisadores

83 Laughter is diferent from the other above because it seem to exceed language in both directions at the same time, as both presymbolic and beyond symbolic; it is not merely a precultural voice seat the same time a highly cultural product which looks like a regression to animality. (Dolar, 2006: p.29)

84 For me, it's more how do I find new voices within myself? How do I not rely on my
old habits? How do discover something new in my own perception of the world? (MONK, AT\&T 1998, p. 75)

85 In ancient Greek theatre the actors wore masks dehichpiness or grief of actor's voices, with their individual nuances and vibrations, could be heard from behind the rigid coverings. The "sounding through" of the actor's own voice gave a sense of the
individual behind the mask's firm outline. The word persona means literally "sounding through". In a society which calls for set roles to be projected to the outside world, the word to mean that sense of self whish we choose to project. We each have myriad personae, some of which we may prefer to keep hidden. (STEINMAN, 1995: $p$ 28-29)

Thanos Vovolis e Giorgos Zamboulakis explicam que a máscara no teatro grego funciona como uma caixa de ressonância para as vozes, proporcionando as condições para a metamorfose do ator e/ou da atriz. Segundo os autores:

$\mathrm{O}$ aparecimento da máscara trágica da era clássica uma representaçáo de um estado de ser do corpo mente. Um estado de meditaçáa é criado dentro do usuário da máscara, seja focalizando o olhar em um único ponto ou pela voz - ou mais especificamente - pelos gritos, encontrados nos trágicos textos como sons originais, arquetípicos; palavres sem significado léxico e geralmente não traduzívis. Essa parte do lexich e geralo da vocalizaçáa é capaz de evocar uma enorme gam de conotaçóes emocionais. Os gritos correspondem a diferentes caixas de ressonância no corpo humano e levam a uma metamorfose. (VOVOLIS; ZAMBOULAKIS, 2007: p. 1)

86 The appearance of the tragic mask of the classical era is ar entation of a body/min of meditation is created within the mask wearer, either by focusing the by the voice- or more specifically-by the cries, found in the tragic texts as original, archetypical sounds; words without lexical meaning and usually not translatable. That part of vocaan enormous range of emotional connotations. The cries correspond to different resonance chambers in the human body and lead to a metamorphosis. (VOVOLIS, 006: p.1)

$87 \quad$ Through transposture, and voice, Monk seemed huge or small, hearty or withered. She became all the ert place; and old man sleeping, (...), a visionary on a quest, a deer being pursed. I felt the room fill with the spirits of fifteenth century corn peop. 26)
A máscara, nesse contexto, produz uma certa reverberaçáo que intensifica a escuta interna, valorizando o aspecto sonoro e possibilitando passagens por diferentes tipos de vozes que são percebidas no estado de espírito apresentado pela única máscara utilizada pelo grupo. Nesse sentido, "o coro é uma persona com múltiplas vozes" (VOVOLIS; ZAMBOULAKIS: 2007).

A dimensão trágica de Do You Be é criada - não através de máscaras visuais mas a partir da potência e diferença das vozes que provocam uma percepção distinta do mesmo corpo a cada escuta. A tragédia é gerada na "máscara sonora", que carrega também personagens e emoçôes, nem sempre explicitamente nomeadas, mas com uma abertura para a recepçáo e a interpretaçáo segundo a experiência de quem escuta. "Através de transformaçóes de gestos, posturas e vozes, Monk parecia grande ou pequena, saudável ou definhada. Ela se tornou todos os habitantes deste lugar deserto; um velho dormindo, um visionário em uma missão, um cervo sendo perseguido." ${ }^{87}$ (STEINMANN, 1995: p. 26)

O que significa Do you Be?

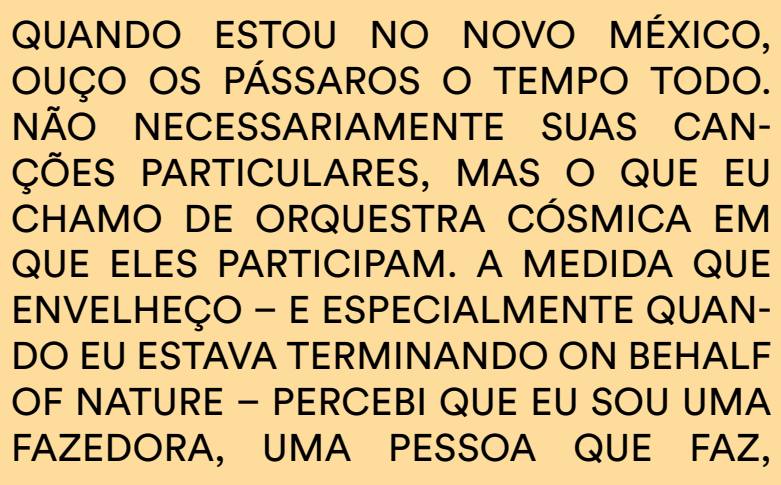


FAZ, FAZ. MAS AGORA ESTOU TENTANDO APRENDER A SER, SER, SER. ENTAOO,

MUITAS VEZES EU APENAS SENTO LA E

OUCO, MEIO QUE COMO UM CACHOR-

RO VOCE Sh

RO. VOCE SABE COMO OS CAES SENTAM

EVIRAM A CABEÇA E SIMPLESMENTE ES-

CUTAM? AQUI ESTÁ OS GRILOS FAZEN-

DO SUA ENTRADA. E LINDO, OS RITMOS

E PROCESSOS SÃO TÃO LINDOS. AFINI-

DADES ANIMAIS? EU GOSTO MUITO DE

GUAXININS.

$($ MONK, 2017)

É possível que a conjugação verbal de Do You Be se encontre relacionada às práticas de meditação de Meredith Monk. A artista reconhece a sua prática artística como uma prática espiritual, e essa ligação se fundamenta no processo da contemplaçăa ${ }^{89}$. Em seu livro "Mente Zen, mente de principiante" (1994), o mestre Suzuki explica:

\begin{abstract}
Prática de meditaçáo. Enquanto sentados, nós somos nada, nem sequer nos damos conta do que somos: apenas sentamos. Mas quando nos levantamos, então estamos aí! Esse é o primeiro passo na criaçāo. Quando você está aí, todas as outras coisas também estão; tudo é criado a um só tempo. Quando emergimos do nada, quando todas as coisas emergem do nada, vemos tudo como uma criaçấo nova e original. Isso é não-apego. (SUZUKI, 1994: p. 62)
\end{abstract}

Meditar é se preparar para a possibilidade de descoberta do mundo e do e ao mesmo tempo. Um eu vazio, a partir do qual tudo é potência. O eu emerge a cada saída da postura Zazen, assim como também um novo mundo é percebido. No entanto, o mundo interior e o mundo exterior são também um único mundo:
Quando praticamos zazen, nossa mente sempre se- gue a respiraçáo. Quando inalamos, o ar entra em nosso mundo interior. Quando exalamos, o ar sai para o mundo exterior. $\mathrm{O}$ mundo interior não tem limites e o mundo exterior também é ilimitado. Nós dizemos "mundo interior" e "mundo exterior", mas, na verdade, só há um único mundo. Nesse mundo sem limites, a garganta é uma espécie de porta de vaivém. $\mathrm{O}$ ar entra e sai como alguém passando po uma porta de vaivém. (SUZUKI, 1994: p. 26)

Relembrando os inícios da sua carreira, Monk considera que o budismo zen já se encontrava implícito na estética da sua obra, equivalente segundo ela, aos fundamentos budistas posteriormente praticados pela artista: mente aberta, mente de
88 When l'm in New Mexico I listen to birds all the time. Not necessarily their
particular songs, but particular songs, but what I call the cosmic te in. Especially as I get older-and especially as I was finishing On Behalf of Nature-I've realized Im a doer, a person who does, does, does. But now I'm trying to lear often just sit there and listen, kind of like a dog. You know how dogs sit and turn their heads, and simply listen? Here are the crickets making their entrance. It's gorgeous, cesses are so beautiful. Animal affinities? like raccoons very much. https://www.artinamericamagazine.com/newsfeatures magazines/ in-the-studio-meredith-

89 Hoje, eu gostaria de falar sobre a você se senta na posição de lótus completo, seu pé esquerdo fica sobre sua coxa direita, seu

pé direito, sobre a coxa esquerda. Ao cruzarmo as pernas desse jeito, perna esquerda e outra direita, elas se tornam uma só. A postura expressa a unidade da dualidade: nem dois, nem um. Este é o ensinamento mais importante: nem dois, nem um. Nosso corpo e mente náo são pensa que seu corpo e mente são dois, está errado. Se pensa que são um, também está errado. Nosso corpo e mente são dois e um ao mesmo tempo. Habitualmente, não é um, é mais do que um; que se algo não é singular, é plural. Mas, na prática, nossa vida não é só plural, é também singular. Cada um de nós é duas coisas ao mesmo tempo: depen(SUZUKI, 1994: p. 22)

90 What I love Zen máster who from Japan to America in the late fifties, is the way he talks about beginners mind: that everything is a possibility. If it is "expert's mind you already think you know what ties. But beginner's mind allows for everythin to come in. (MONK in MARRANCA, 2014: p.115) principiante, aceitaçáo, contemplaçáo, observaçáo do medo. A mente de principiante segundo Monk possibilita adentrar no desconhecido.

O QUE EU AMO NO SUZUKI ROSHI, UM
MESTRE ZEN QUE VEIO DO JAPÃO PARA
A AMÉRICA NO FINAL DOS ANOS 5O, É
A MANEIRA COMO ELE FALA SOBRE A
MENTE DE PRINCIPIANTE: QUE TUDO É
UMA POSSIBILIDADE. SE É "MENTE DE ES-
PECIALISTA" VOCÊ JÁ ACHA QUE SABE O
QUE É, ENTÃO VOCÊ LIMITA AS POSSIBI-
LIDADES. MAS A MENTE DE PRINCIPIAN-
TE PERMITE QUE TUDO CHEGUE. (MONK,
2014: P.115)

Segundo esta perspectiva, a confiança no material e no fluxo da voz estabelece um estado meditativo e a meditaçáo cria espaços para o fluxo musical. Para Monk a mente de principiante é essencial na hora da performance, uma mente aberta aos acontecimentos e às variaçôes inevitáveis. "A prática da mente Zen é a mente de principiante. A inocência da primeira pergunta - o que sou eu? - é necessária em toda a prática Zen. A mente do principiante é vazia, livre dos hábitos do experiente, pronta para aceitar, para duvidar e aberta a todas as possibilidades." (SUZUKI, 1994: p.13)

Desenho de Meredith Monk para a divulgação da Ópera Vessel (1971) que contem $D o$ You Be no repertório.

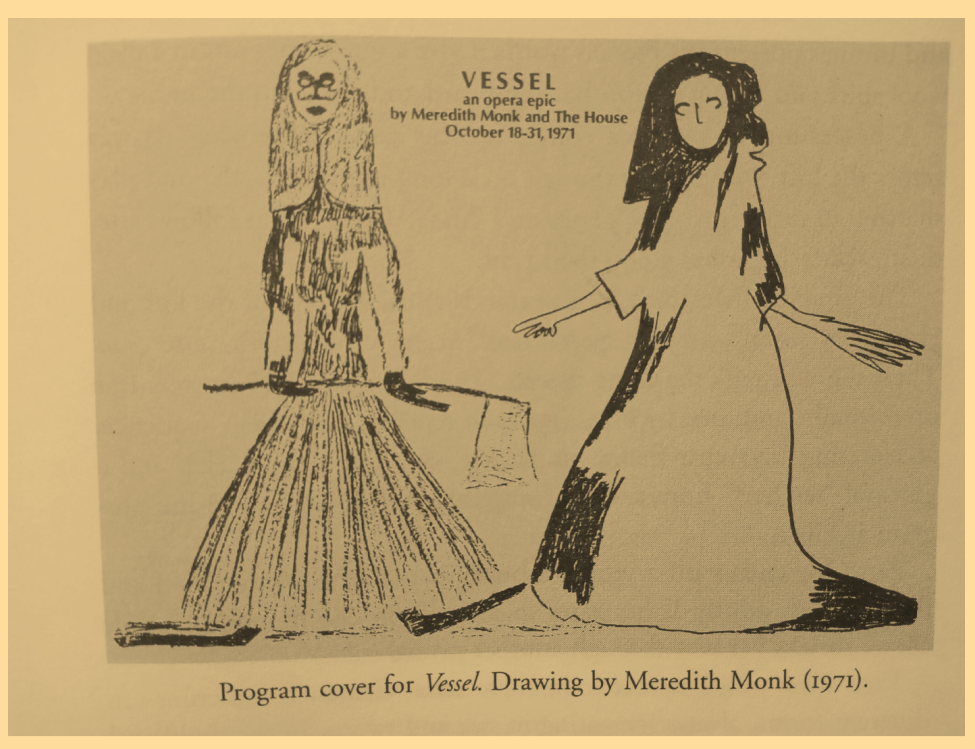

Imagem extraida do livro Meredith Monk (1997), editado por Deborah Jowitt. 


\section{PAISAGEM VOCAL: CHANGE (FAIXA NOVE, 3:45)}

FIQUEI MUITO INTERESSADA NA IDEIA DA MANDALA, QUE E UMA FORMA PADRONIZADA. NAS MANDALAS BUDISTAS OU TIBETANAS CLÁSSICAS, NORMALMENTE VOCÊ TERÁ UMA FIGURA CENTRAL, COMO UM BUDA. ENTÃO, NOS QUATRO CANTOS, DIFERENTES ASPECTOS DE SUA VIDA. OU VOCÊ PODE TER SEIS LADOS ONDE TERÁ DIFERENTES IMAGENS DE SUA VIDA, MAS SEMPRE TERÁ UMA FIGURA CENTRAL. (MONK, 2014: P. 90) ${ }^{91}$

Change é uma peça em camadas, uma experiência de imersão no som a partir de ideias cíclicas. A partir de uma figura central cria-se uma paisagem de vozes interligadas de começo a fim. São trabalhados os planos pelas cores (emissōes vocais diferentes) em relação à figura central (melodia modal inicial).

Na paisagem vocal ouvem-se as respiraçôes, os espaços entre as vozes, e o espaço que cada uma das vozes cria. Change significa mudança. As vozes vão aos poucos se tornando outras, por meio de variaçóes na qualidade vocal de cada uma delas; sonoridades que se contaminam e influenciam a medida que são elaboradas. Aqui ganha relevância o conceito poético de "vozes viajantes" (travelling voices), apresentado por Monk. A importância do ato de viajar, do processo de ir de um lugar a outro, e não só do resultado obtido a partir da variedade de emissōes vocais apresentadas. O que interessa é o processo de transformação gradativa, um caminho de passagem, onde as vozes são filtradas por alguma força externa.

A paisagem vocal se inicia com uma emissão coberta, em uma melodia modal de duas frases longas (0:00 a 0:10) com [a]. A melodia ligada alterna intervalo de terça menor e de segunda maior, partindo sempre da mesma nota. A segunda voz (0:33 a 0:57) segue o mesmo movimento rítmico uma quarta embaixo da voz inicial, imitando suas articulaçôes, evidenciando o modo dórico na utilizaçáo da sexta maior. A segunda voz também é emitida com [a] se fundindo com a melodia inicial. Entretanto, ela possui uma variação a partir da segunda exposição (0:58 a 1:10)

Após algumas exposiçôes da primeira melodia e da segunda harmonizando esta, emerge uma voz de fundo (1:24), de sustento do modo (la dórico) e ao mesmo tempo de continuidade e resoluçáo; um som pedal que ressoa num outro espaço, ao longe. Essa voz é a que traz uma mudança em termos de tipo de emissão, porém dando consistência a harmonia que já estava estabelecida. Ao mesmo tempo se apresenta uma voz aguda (1:24) com vibrato, também constante e distante, mas com um ataque mais acentuado, com uma duração menor que o primeiro pedal de sustentaçấo do modo.

Em princípio torna-se difícil definir exatamente qual é o tipo de emissão do primeiro pedal, não sendo possível distinguir evidência de vocalidade, por causa da distância e do ataque indefinido, por causa do tipo de reverberaçáo que modifica a qualidade vocal. Aos poucos os dois pedais váo se aproximando, com uma emissáo nasalizada e logo ruidosa (2:29), perdendo, lentamente, a clareza harmônica inicial. $\mathrm{O}[\mathrm{a}]$ das vozes apresentadas em um primeiro momento se fecha gradativamente, apresentando outras vogais, nasais e fechadas, a medida que os pedais ganham presença. A nasalidade, e logo a rugosidade das notas pedais contagia as ideias melódicas iniciais (2:52), formando uma massa de ruído vocal que se perde no espaço.
$91 \quad$ I became very mandala, which is a pattern form. In the classic Buddhist or Tibetan mandalas, usually you will have a central figure, like a Buddha. Then, at te aspects of his life. you might have six sides, where you'll have different images of his life, but you will always have a central figure. (MONK MARRANCA, 2014: p.90) 


\section{A VOZ QUE DANÇA. A VOZ TÃO FLEXÍVEL QUANTO A COLUNA: \\ DUNGEON (FAIXA DEZ, 6:49)}

COMO VOCÊ CRIA UMA EXPERIÊNCIA QUE PERMITA ÀS PESSOAS UMA NOVA MANEIRA DE VER E OUVIR? (MEREDITH MONK) 92

Dungeon começa com a chegada de alguém (0:00 a 0:25): sons de pegadas em superfícies com releves, talvez de folhas de um quintal, e um fundo ambíguo no que se refere ao espaço interno e externo. Em um primeiro momento ouvem-se latidos ao longe, sons de cigarras e um fundo de rua. Este fundo (camada de som ambiente) continua ao longo da peça e por mais alguns segundos logo depois das vozes saírem de cena. Na descrição de Key, Monk apresenta Dungeon como uma música inicialmente composta sem acompanhamento. Porém, no disco, Collin Walcott cria uma base rítmica com o instrumento que foi denominado em Key como mrdingam.

Ao longo da pesquisa não foi encontrado nenhum registro de instrumentos clássicos da Índia com este nome, mas com o nome de mridangam, o que leva a concluir que talvez o instrumento em Key fosse uma variaçâo do instrumento original, e que Walcott fosse também um luthier, além de percussionista e produtor. A sonoridade do mrdingam no disco é bastante diferente do mridangam. Ao perguntar para a artista Lanny Harrison si o mrdingam é o mridangam indiano, ela disse:

\begin{abstract}
Sim, o Mrdingam utilizado era o indiano. Vive ao lado do meu santuário, no norte do Estado de Nova York (não estarei lá até março) e precisa de novas cabeças...não sei quando isso acontecerá. Collin não fazia instrumentos de cordas, mas ele tocava bateria, fazia correias, fez uma grande sanza $a^{93}$. Ele tocava quase tudo, menos horns e piano. Ele era um músico extraordinário com ouvidos como antenas e mão mágicas. (HARRISON, 2019)94
\end{abstract}

O mridangam original é um instrumento de percussão de origem indiano que produz uma grande variedade de timbres. Do lado direito possui diferentes alturas e sonoridades que são acessadas pelas diferentes técnicas de dedos. Do lado esquerdo se encontram os sons mais percussivos, com menos reverberação e algumas variaçōes de altura. nismos laríngeos enseja novas terminologias. Harry Hollien, um dos dos com a pesquisa dos registros vocais, é autor de uma nomenclatura que se tornou muito conhecida no Brasil: ele divide os registros em pulso (o equivalente ao vocal fry), modal ou elevado (o equivalente dentro do registro moda se encontram os subregistros de peito, misto $\mathrm{e}$ cabeça, ou grave, médio eagudo. (MARIZ, 2013: p.56)

96 Yodeling é um técnica vocal particular uma variedade de dife rentes culturas musicais ao redor do mundo, desde os Alpes Suíços, ao início da música country americana, até a floresta hopical central africana. https://www.lawrence. edu/conservatory/areas con_brio/baka

97 INÉS: Em

"Plastic Ono Band"(1970) Yoko Ono utiliza bastante essa tècnica. Monk menciona essa técnica dem varias oportunidaexatamente como é produzida. Não possuo bibliografia que confirme cientificamente que de fato a ação esteja focada na estrutura "epiglote" pelo que seria interessante fazer uma confirmar essa definição.

$98 \quad$ I believe that when you get the music into the body, you bypass the kind of visual memorization process that actually gets in the
way. (MONK, 1990: p. 3)
Em Dungeon, o mridingam de Walcott define o tempo em um pulso constante que determina tons e ritmos criando um ostinato. Voz e mrdingam entram juntos $(0: 26)$. A exploração de vogais predomina nessa faixa, principalmente com [i], [a], [e], [u], e [o] na região modal ${ }^{95} \mathrm{da}$ voz, em um sub - registro misto, em uma regiāo aguda da voz, no primeiro momento em que a voz acompanha o ritmo que o $\mathrm{mr}$ dingam estabelece. Monk alterna ataques com " $m$ " que resolve em alguma das vogais apresentadas imitando o ritmo da percussão. A articulação rítmica das vozes varia na medida em que este pulso sugere uma forma que não se modifica.

Dungeon é uma das peças em Key que mais qualidades vocais apresenta. A exploraçáo de vogais é logo desdobrada em diferentes vocalidades como a mudança rápida entre mecanismos laríngeos e ressonâncias, como na técnica do yodel (2:22 a 2:27) ${ }^{96}$, o golpe de epiglote (3:41 a 3:54 e de 4:42 a 5:00)97, o drive (2:04 a 2:14), os prolongamentos de vogais com acentuaçóes a partir de glissandos (3:08 a 3:33), vocalidades que sugerem uma fala ( $3: 22$ ao $3: 31)$, os vibratos e os sons surdos respiratórios $(2: 28$ a 2:41)

\section{PERCEBI QUE MINHA VOZ PODERIA TER A FLEXIBILIDADE DE MEU CORPO, QUE EU PODIA ARTICULAR UM VOCABULÁRIO PARA MINHA VOZ ASSIM COMO EU HA- VIA CONSEGUIDO UM PARA MEU CORPO. (MONK,1996: P. 206)}

Em toda vocalidade há um ritmo externo e um ritmo interno. Em Dungeon, o mrdingam estabelece o ritmo externo e as vozes são consequência da experiência de um ritmo interno em relação ao primeiro. $\mathrm{O}$ ritmo interno se refere ao sistema respiratório, aos ciclos cardíacos, ao sistema sanguíneo, e as variaçóes físicas/emocionais que ocorrem durante a performance a partir das relaçôes com o contexto. O corpo é ao mesmo tempo ritmo interno e caixa de ressonância das vozes; é produtor e ressonador do som vocal.

\section{EU ACREDITO QUE QUANDO VOCE COLO- CA A MÚSICA NO CORPO, VOCÊ SUPERA O TIPO DE PROCESSO DE MEMORIZAÇÃO VISUAL QUE REALMENTE ATRAPALHA. (MONK, 1990: P. 3) ${ }^{98}$}


Como compositora de imagens, movimentos e sons, Monk nâo trabalha a partir da escrita, mas a partir das vivências do corpo vocal. Nessa experiência, a peça se encontra latente no próprio corpo antes de ser escrita no papel ou gravada, ela se manifesta como necessidade física e emocional através da prática composicional durante a performance.

\section{AS VEZES CRIO COMPOSIÇÕES QUE \\ SÃO VOZ, MOVIMENTO E MÚSICA INS- \\ TRUMENTAL SIMULTANEAMENTE. NÃO CONSIGO FAZER ISSO NO PAPEL. (MONK,}

1990: P. 3) $)^{99}$

Na pesquisa de movimento do corpo Monk cria movimentos ligados às figuras rítmicas da composição musical/vocal, apresentando de modo geral, uma complementação com as vocalidades. Entre tanto, cada gesto vocal se configura como um movimento que apresenta uma nova versão do mesmo corpo em cada emissão. A exploração das vozes é uma pesquisa de movimento mais aguçada em relação às articulaçóes do corpo na medida em que a potência das mesmas torna-se o veículo principal de transcendência durante a performance.

Em Dungeon, cada uma das propostas vocais se apresenta como uma personagem e entre elas existe um pacto conduzido pela vontade de quebrar com este pulso/tom constante. As vozes se debruçam sobre a pergunta: como quebrar com esse tempo? Cada personagem parece chamar a seguinte, em movimentos de acentuaçôes e na repetição de uma mesma frase com aumentos gradativos na intensidade.

Quem insiste e delimita a forma é o mrdingam. Dungeon é o calabouço, cujas grades se encontram dentro e fora do corpo; um corpo condenado à repetiçấo que procura modos de se revelar, alterando o seu ritmo interno, que é biológico, mas que é programado culturalmente para o seu funcionamento.

Desta forma, compreendermos que quando um cor-

po é inserido na sociedade, the são atribuídas formas

e funçōes, e tal mecanização torna-o um organismo

- ou seja, o corpo abandona a potência, sendo orga-

nizado e reduzido para um estado de corpo, onde se

almeja um fim determinado, a organização e produ-

çáo. (ASCENÇO SOARES; UHNG HUR: 2017:

p.16)

Monk inventa a escuta da voz que realiza trajetos como quem dança ou participa de uma luta, apresentando diferentes consistências físicas, esquecendo aos poucos a nossa percepçáo funcional do mundo, apresentando um corpo vocal que cria estratégias para cavar uma saída do calabouço. 


\section{CAPITULO III}

\section{A Voz como Prática}

Voice as Practice no Garrison Institute: um retiro com Meredith Monk e Ellen Fischer. Do dia 15-12 ao 17-12-2017

100 The human sibilities. It can open up memory; it can point to the future. It can age; it can transform. Our world needs the open-heartedness that is so natutal to the voic the for which we don't have words. This workshop offers a place where voice, movement, and image intersect to create an opportunity for participants to discover their own personal richness. A ditation is to follow the breath. We will explore how the outbreath expands into sound, tone and resonance and work with exercises to deepe our listening and awareness of the inspiration of our environment and
voices coming through us.The playful aspect of creation and the joy of discovering our unique vocal qualities will be emphasized as a way of connecting us to the healing power of the voice. During the workshop, talk on the relationship she has crafted between her Buddhist practice and her art. https://www. garrisoninstitute.org vent/meredith-monk-
A VOZ HUMANA POSSUI POSSIBILIDADES ILIMITADAS. PODE ABRIR A MEMORIA; PODE APONTAR AO FUTURO. PODE ENVELHECER; PODE SE TRANSFORMAR O NOSSO MUNDO PRECISA DO CORAÇÃO ABERTO QUE É NATURAL À VOZ. (MONK, 1990: P. 3) $)^{100}$

A Voz como Prática é o título de uma série de retiros/workshops que Meredith Monk conduz nos Estados Unidos ou como artista convidada em outros lugares do mundo. Tive a oportunidade de participar de um dos retiros graças a uma bolsa concedida pela organização do Garrison Institute, instituição budista que recebe diferentes apoios de iniciativa privada para artistas, educadoras e trabalhadoras da saúde. Texto de divulgação do Retiro:

$$
\begin{aligned}
& \text { A voz, o instrumento original, é uma linguagem elo- } \\
& \text { quente do coraçáo que delineia energia para a qual } \\
& \text { não possuímos palavras. O workshop oferece um es- } \\
& \text { paço de intersecçáo entre voz, imagem e movimento } \\
& \text { para criar uma oportunidade para os participantes } \\
& \text { descobrirem sua riqueza pessoal. Uma instrução bá- } \\
& \text { sica em meditaçáa é seguir a respiraçáa. Vamos ex- } \\
& \text { plorar como a expiração se expande em som, tom } \\
& \text { e ressonância e trabalhar com exercícios para apro- } \\
& \text { fundar a nossa escuta e consciência da inspiração do } \\
& \text { nosso ambiente e vozes que vêm através de nós. O } \\
& \text { aspecto lúdico da criaçáo e a alegria de descobrir nos- } \\
& \text { sas qualidades vocais únicas serão enfatizados como } \\
& \text { uma forma de nos conectar ao poder de cura da voz. } \\
& \text { Durante o workshop, Meredith também dará uma } \\
& \text { palestra sobre o relacionamento que ela criou entre } \\
& \text { sua prática budista e sua arte. }
\end{aligned}
$$

O retiro foi um modo de acessar à prática cotidiana de Monk, apresentando uma série de exercícios que a artista realiza na sua rotina, no conhecimento do corpo vocal a partir da meditação.

Meditar [escutar], Dançar [escutar], Cantar [escutar]. Esses quatro verbos resumem a experiência do fim de semana em Garrison (NY, EUA) com as artistas Meredith Monk e Ellen Fisher. A escuta traçou uma linha entre todos os exercícios, 
seja no silêncio ou na movimentaçáo do corpo e da voz. Escutar o espaço, o corpo, o outro; as vozes em conjunto; uma escuta que é intencional e profunda, mas também uma escuta que reconhece a conexão entre os sentidos e a influência de outras percepçóes físicas não cocleares.

Acordar, tomar o café da manhâ, se encontrar na sala de meditaçâo com aqueles primeiros raios de sol entrando pelos vitros das janelas, sentar e fechar os olhos, escanear o próprio corpo: escutar as indicaçóes de Monk para a meditação. O silêncio, os pensamentos de cada um dos cinquenta participantes ${ }^{102}$ sentados em roda, as pálpebras leves e os olhos semiabertos, o olhar calmo projetado seis passos na frente do corpo, o foco na expiração, os pensamentos se dissolvendo no espaço.

Cada encontro era iniciado deste modo, meditando sentadas por aproximadamente quinze minutos. Logo chegava a hora do aquecimento corporal conduzido por Ellen Fisher. Alongamentos, atravessamentos e exploração do espaço; exercícios focados na representação de imagens a partir do corpo. Uma vez aquecidas, Monk começava suas indicaçôes para acordar a voz e iniciar a experiência e escuta das vozes em grupo. Dicas de respiração e postura, exercícios com consoantes fricativas, humming, arpegios e exercícios de ressonância em diferentes partes do corpo com vogais. Monk ofereceu ferramentas referidas à saúde vocal demonstrando exercícios para náo forçar a laringe. $\mathrm{O}$ pescoço alongado e a postura alinhada e ao mesmo tempo relaxada; cantar sem ultrapassar o grupo e entender o canto como prática espiritual; estas foram indicaçōes recorrentes.

Durante os três dias, aprendemos algumas composiçōes de Meredith Monk que cantamos em cânone, algumas delas junto com movimentos do corpo predefinidos pela artista. Várias composiçôes apresentavam células rítmicas simples que na combinação das entradas das vozes formavam polirritmias. Os movimentos ajudavam a entender essas entradas e contrapontos.

O trabalho de movimento proposto por Monk se encontra vinculado à estrutura rítmica que ela cria nas composiçôes vocais. A pesquisa de movimento é algo que no geral vem em um segundo momento, se constituindo a partir da composição em relação à arquitetura e a uma busca de complementaçáo do trabalho vocal. Ao mesmo tempo a forma é muito presente no tipo de movimentação, há uma simetria nas suas propostas em dança, ao delimitar espaços equidistantes entre as performers. Os tensionamentos se encontram mais presentes na junçáo das vozes do que na junção da pesquisa de movimento do resto do corpo. No entanto, as propostas pedagógicas de Monk foram mais pautadas na improvisação no que se refere à movimentação do corpo do que na pesquisa de vozes. Para as vozes sempre havia uma definição melódi- ca, rítmica, de fonemas e/ou de letra.

No último encontro foram realizados exercícios de experimentação em grupo, pensando o espaço, o movimento e a vocalidade; composiçóes realizadas a partir de imagens sugeridas por Monk, como o deserto, o organismo celular, a floresta e outros. No último exercício o grande grupo foi dividido em grupos de seis pessoas para trabalharmos a ideia de organismo celular, conceito investigado por Monk no seu concerto Celular Songs - estreado em 2018. A partir dessa ideia foram trabalhadas as vozes e deslocamentos do espaço como em uma grande engrenagem entre as participantes. Cada grupo escolheu um espaço para a performance dentro do Garrison Institute, uma movimentação que evidenciasse uma certa interdependência entre as performers, e qualidades vocais que pudessem atravessar todos os corpos sem grandes dificuldades, criando um tecido corporal e sonoro em comum.
102 INÉS: Meredith Monk realiza esse retiro
no Garrison Institut (NY) uma vez por ano. de diferentes lugares do mundo. O retiro, apesar de uma experiência silenciosa, é uma experiência coletiva em todos os momentos. 
PEÇA I - SOLO PARA VOZ DESACOMPANHADA: UNA MIRADA DESDE LA ALCANTARILLA ${ }^{103}$

Sinopse: Uma poesia da escritora argentina Alejandra Pizarnik é ignição para o solo Una mirada desde la alcantarilla - uma escuta da cidade pelo seu subterrâneo. A memória dessa escuta é recriada por vozes na tentativa de reconstruir os materiais a partir dos resquícios sonoros e das reverberaçóes do corpo.

Una mirada desde la alcantarilla ${ }^{104}$ é uma performance cujo processo de criaçáo começou em 2016 como um solo de vozes, na invençấo de um repertório de vocalidades provocadas pelas imagens poéticas de Alejandra Pizarnik.
Alejandra Pizarnik (1936 - 1972)

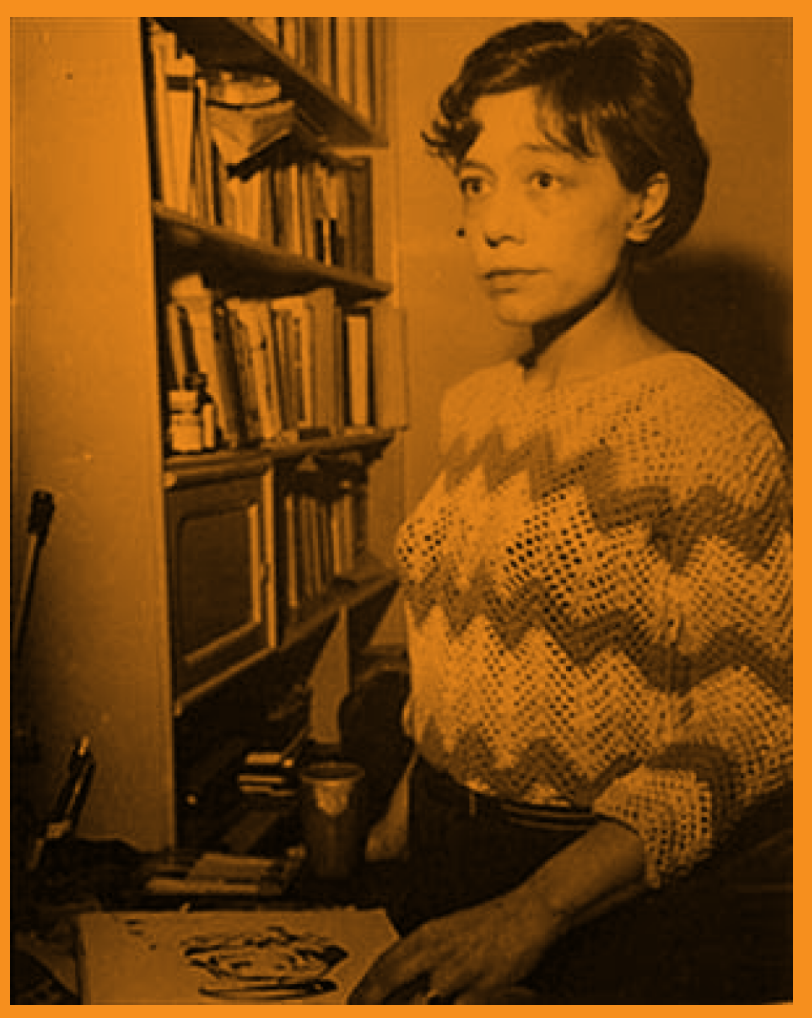

Poeta nascida em Buenos Aires no dia 29 de abril de 1936, em uma familia de migrantes da Europa oriental. Estudou filosofía e letras na Universidade de Buenos Aires e. mais tarde, pintura com Juan Batlle Planas. Entre 1960 y 1964, Pizarnik morou en Paŕs mais tarde, pintura con Juan Batlle Mlanas. Entre 1960 y 1961, Pizas, publicou pon Par's onde trabahlou para a revista Cuadernos e algumas editoras francesas, publicou poemas cricicas en vátios jonais, traduziu a Antonin Artand, Henni Michaux, Aimé Cesaine, e Yves Bonnefoy, e estudou históna da religiáo e literatura francesa na Sorbona. Após seu retono a Buenos Aires, Pizarnik publicou très dos seus principais volumes: Los trabajos y las noches, Extracción de la piedra de locura e El infierno musical, assim como seu trabalho en prosa La condesa sangrienta. Em 1969 recebeu uma bolsa Guggenheim, e em 1971 uma Fullbright. No dia 25 de setembro de 1972, enquanto passava um fim de semana fora da clínica onde se encontrava internada, Pizarnik morreu de uma overdose intencional.
103 INÉS: Essa peça da tese de doutorado da pesquisa Holderbaum (2019).

104 INEÉS: Versão de ensaio prévio à estreia
(2016). Ideias iniciais

https://soundcloud.con ines-terra/una-miradadesde-la-alcantarilla-enaio-13092017.

da: realizada no Judson Church em Nova York, 20/5/2019: https://www. youtube.com/watch?$v=$ SQKjUlufTcY\&feat 
Dungeon, com acompanhamento. Interessa nessa experiência ver como uma mesma ideia ganha diferentes formas, e como a performance vocal pode se desdobrar em diferentes contextos com estruturas específicas, assim como valorizar as transformaçōes de um corpo ao longo do tempo, ao continuar o mesmo trabalho durante os anos.

A pesquisa foi aos poucos sendo direcionada nas relaçóes visuais e sonoras, na construção da performance, embora inicialmente o solo tenha sido criado principalmente focado na pesquisa de vocalidades. Como parte do processo foi gravado um vídeo $^{105}$. O vídeo alimentou ideias específicas da linguagem, focando na repetição, nas diferentes perspectivas de quem assiste a performance, e na montagem de um corpo cujo final do instrumento (a boca) não se encontra em evidência. Ao não ter a possibilidade de apresentar em um espaço onde a performance pudesse ser assistida desde cima, gravar um vídeo era uma possibilidade de enxergar essa perspectiva do espaço desde diferentes ângulos.

\section{Aspectos técnicos:}

Inicialmente escolhi algumas sonoridades do meu repertório vocal para criar um solo de no máximo dez minutos. Realizei um roteiro e gravei uma versão por dia durante quinze dias antes da estreia (2016). O solo não é uma improvisação, porém a improvisação é um elemento fundamental durante a performance; como um modo de recriar no corpo os materiais que foram escolhidos e de descobrir outros novos entre estes, ligados à experiência do dia, às pessoas presentes e ao espaço que é gerado.

O que conduz o solo são as ligaçôes e tensões entre as sonoridades escolhidas previamente, o que há entre estas, respiraçôes e ajustes do corpo vocal que acabam criando outros lugares durante a performance. Considero que o meu trabalho vocal é baseado nessa pesquisa durante a exploraçáo da voz. Posso descobrir qualidade vocais e talvez catalogá-las e repeti-las, mas o meu interesse mais profundo é sobre aquilo que ainda náo sei e que aparece durante a performance, na tentativa de trazer as imagens que eu criei da poesia ou de outras vivências, as ressonâncias das vozes que eu escolhi e suas reverberaçôes no corpo. Na tentativa descobro sempre outros corpos vocais que ainda não entendo como são produzidos.

Essa abertura me permite uma certa desconfiança dos meus processos mais racionais e definidos em tempo diferido, valorizando tanto esse momento inicial de planejamento como as contingências durante a performance. Os dois momentos se encontram interligados e são dependentes um do outro, já que se não houvesse exA primeira delas é a escolha da realizaçáo de um solo que apresent 
perimentação não haveria planejamento possível. Este aspecto também se refere à exploração do movimento do corpo.

\section{A performance foi apresentada em sete oportunidades:}

Como performance vocal:

1) No Dissonantes: ciclo de mulheres na música experimental, organizado por Renata Roman e Natacha Maurer em 2016.

2) No seminário de Vozes Performáticas organizado pela Prof. Dra. Wânia Storolli na Unesp em 2016

3) Como convidada do Macrofonia, ciclo de palavra, imagem e som, realizado na Casa da Luz, Jeanne Callegari e Reuben da Rocha em 2017.

Na pesquisa de movimento:

4) No evento Open Performance da organização Movement Research em Nova York (apresentaçáo de um trecho em processo) em 2018.

Nesse evento foi apresentada uma versão de oito minutos do processo que estava realizando sobre o movimento das vozes e do corpo como uma única partitura. Nessa mesma noite foram apresentadas mais duas performances, uma da artista Jô Stewart que tem trabalhado com Meredith Monk no seu último concerto Celular Songs (2018), e uma performance da artista Taina Bey. Apesar de o evento ser organizado por ordem de inscrição (e não por uma curadoria), as três performances tinham elementos em comum, como por exemplo, o entendimento da voz como parte do movimento (no caso da performance de Stewart e da minha). No final do evento foi realizada uma roda de comentários do público em colaboraçáo com as artistas. Foram mencionadas questôes como a alternância entre a representação de uma personagem e a auto referencialidade, a relação entre movimento e som (apontando para a contradição entre estes em alguns momentos), o movimento do corpo e das vozes como uma única partitura. a fonte e o som e a possibilidade de não evidenciar sempre a origem das vozes. Uma das falas que me chamou mais a atenção foi de uma artista que recriou com as suas palavras a poesia de Pizarnik, apesar de não ter nenhum contato explícito com a mesma previamente, ou mesmo durante a performance, já que não utilizo palavras. Um dos meus desejos durante a performance é afinar modos de encarnar a poesia sem falar as palavras.

Seguem alguns comentários feitos após a apresentaçấo. Como não possuo contato com todas as pessoas que participaram, mantive o anonimato dos depoimentos.
"Eu acho que quando as pessoas trabalham com vocalizaçáo experimental, as pessoas têm reaçóes muito fortes...e você tem que nos ensinar como ver a sua peça. Todo mundo estava rindo no começo, porque voce estava fazendo um som engraçado con a sua voz, que náo ouvinos com muita frequência. E como continuou, ficou muito lúgubre para mim ficou muito real. E foi interessante como você não mudou, mas todo mundo sim."

"Eu realmente amei como no começo foi como um longo tempo apenas o som saindo desta criatura, quase como se você fosse uma pedra ou algo assim. Seu grito era insano. Achei o movimento de sua mãos muito disjuntivo na segunda parte. Eu senti que era um gesto que você queria fazer e que a sua voz provocava uma outra coisa no seu corpo, o oposto do começo. Eu me perguntava sobre o valor do disjuntivo."

"Eu também estava curiosa nesses momentos em que você estava em silêncio, quando você olhava a gente fez contato visual, e isso foi incrível. E foi assim..., eu pensei que você fosse uma criatura que náo era desta terra, mas quando você olhou para mim você era tão humana como realmente olhar do, como você. Eu me pergunto sobre a visibilidade do, como voce. Eu me perguno sobre a visibilidade e a invisibilidade, tanto como olhar para você como sobre o seu olhar para o público, e como esse relacionamento especial poderia funcionar."

"O movimento em sua maior parte era de fluxo e, mais tarde, havia esse tipo de movimento de ser tomado por um tipo de energia ou como um tai chi energético, carregando e transmitindo energia. Onde está a voz, a localização da voz em momento diferentes? porque eu acho que com o tipo de experiência paralela que tenho de voz e movimento, eu sinto que há muitas oportunidades para os diferentes espaços que esses dois criam (movimento e vozes), eu penso assim, quando você estava assim (no chão, olhando para baixo) com voz, pra mim écomo náo poder ver a cabça ou o vosto de alguém, realma náo poder ver a cabeça ou o rosto de alguém, realmente tambén cria a sensaça de que poderia vir de qualquer lugar. Entáo pra mim, também se tornou uma questão da relaçáo entre a fonte e o som. Porque eu acho que visualmente você poderia fazer qualque coisa e vocalmente, você estava fazendo isso. Havia certos sons que eram mais localizados e havia outro que poderiam estar em qualquer lugar, e eu me pergunto se há outras maneiras de fazer isso com outro tipo de movimento ou postura ou orientação de si mesmo para si mesmo." 
"Não percebi que a peça tinha acabado. Pensei: essa personagem está sentando conosco no círculo."

5) Na programação Cartografias do Possivel do Centro de Referência da Dança (reestreia) em 2018.

Essa foi a estreia da performance em sua versão mais longa (30 minutos) e foi realizada na sala cênica do CRDSP. Nessa versão, contei com o trabalho de luz de Maria Basulto, e com o auxílio de Julia Teles no som. O solo já se encontrava dividido em três atos, e no segundo apresentava uma paisagem vocal gravada. As vozes eram exploradas no espaço sem amplificação, com exceção do último ato, momento em que vocalizo no microfone. A experiência de planejar um mapa de luz fortaleceu a performance. Durante a mesma senti que o caminho não precisaria ser traçado unicamente pelos meus deslocamentos e vocalidades, mas que a luz desenharia outros caminhos para a percepçáo. Ao mesmo tempo, a luz apontou e ressaltou espaços do corpo que eu não planejava colocar em total evidencia.

6) Como artista e pesquisadora convidada da Universidade Federal do Sul da Bahia (UFSB) em 2018

Essa apresentação foi feita para xs alunxs de graduação e xs professorxs da universidade. Nesta ocasião precisei simplificar a luz, o espaço acústico tinha pouca reverberação e o chão não era o adequado para o trabalho de movimento. Formei um chão de tatame e contei com dois refletores que coloquei um de cada lado na frente do espaço delimitado para a performance, criando sombras no fundo. Apesar das dificuldades técnicas foi uma apresentaçáo muito especial de troca com xs alunxs e professorxs. Após as apresentaçóes houve um debate com xs alunxs presentes. Algumas das obervaçóes feitas se referiam à potência e à aflição que o grito provoca, às sombras desenhadas no espaço em relação com as vozes produzidas (como personagens que emergem no espaço cênico), à falta de reverberaçáo no espaço e à importância da mes$\mathrm{ma}$, à escolha previa de vocalidades e aos acontecimentos próprios da performance, entre outros.

Nessa mesma semana dei uma oficina de voz para xs estudantes. Conversamos sobre as impressōes que elxs tinham sobre as próprias vozes e sobre os seus interesses. No geral todxs expressaram o desconforto com a própria voz, por não sentir que estas eram capazes de atingir "certos lugares" formulados a partir das suas referências musicais/vocais. Isto colocou o foco da discussão em questôes como os padrôes vocais da televisão aberta brasileira e os padrōes de gravação e mixagem na música escutada no rádio e nas redes sociais, assim como também a diferença entre a escuta interna da própria voz e da mesma voz gravada. Conversamos também sobre a importância das vozes em relaçáo à biografia pessoal e como o processo de descoberta das mesmas se apresenta como um modo de elaboraçáo constante de si. Todxs demonstraram vontade de explorar em grupo as possibilidades das vozes. Apresentei diferentes modos de investigar a potência vocal de forma individual, em duplas e em grupo, e ensinei um cânone de Meredith Monk a quatro vozes.

7) No evento Movement Research at the Judson Church em Nova York, 20 de maio de 2019 .

Para esse dia fiz uma versão reduzida da performance, com duração de quinze minutos. O Movement Research at the Judson Churché um evento que acontece toda segunda feira a noite na Igreja Judson, com curadoria itinerante, promovendo apresentaçōes de performances em processo e algumas já finalizadas e especificamente adaptadas para esse evento. A limitaçáo técnica no que se refere à luz e ao sistema de som é compensada pelas características acústicas do espaço. Ao se tratar de um espaço histórico, na sua arquitetura e nos seus acontecimentos, desde os anos sessenta, o Judson Church possui um público constante e heterogêneo, interessado nos projetos que sáo desenvolvidos no espaço. Por tanto, o público chega nesse contexto por vias diferentes, como a divulgação regular da organizaçáo Movement Research e no intuito de conhecer esse lugar histórico para as artes do movimento. Ao mesmo tempo o evento é compartilhado entre quatro projetos artísticos. Nessa mesma noite foram apresentados os seguintes trabalhos: La Mujer Maravilla Project, Ximena Garnica \& Shige Moriya com o LEIMAY Ensemble, e a coreógrafa Iliana Olalde. Dois dos trabalhos tinham também uma pesquisa de som junto com o movimento. O Leimay ensemble dançava encima de uma plataforma redonda de madeira com microfones de contato que captavam o impacto do peso dos corpos enquanto estes se equilibravam. Complementando esses movimentos, quedas e impactos, o grupo também vocalizava. La Mujer Maravilla Project eram três mulheres que exploravam a performatividade do corpo entendido como feminino, questionando os padróes sociais de beleza e comportamento, ocupando espaços também da plateia. Os saltos criavam padróes rítmicos e as artistas também utilizavam a sonoridade da respiração sincronizada.

Equipe de trabalho do vídeo:

Caetano Tola: imagens e ediçâo do vídeo.

Lucas Ogasawara: imagens e edição do vídeo.

Julia Teles: gravação e edição de áudio.

Clarissa Mosser: luz e sessão do espaço "Galpão do Folias".

Entende-se o vídeo como outro momento do processo criativo, a partir do 
qual quem filma e edita cria e inventa sua própria escuta como quem está assistindo ao vivo e destaca fragmentos. Ao mesmo tempo, há uma direção no sentido das imagens dessa escuta, diretrizes de planos abertos e fechados (fragmentos do corpo), porém nunca focando na evidência da vocalidade (a boca) ou direto no olhar (mirada) Me interessam os planos mais fechados na medida em que mostram lugares do corpo que se modificam a partir da relaçáo com o som, mas não são partes do corpo evidentes ou principalmente entendidas como responsáveis pela respiraçáo e a fonaçấo O vídeo é um desdobramento da performance e não a performance em si. Se trata de uma composição de grades do corpo, do som e das luzes entrecortadas (sombras e multifônicos).

\section{A gravaçáo - 6/5/2018}

Para o dia da gravaçáo foram pensadas algumas estratégias para criar material suficiente para a montagem do vídeo considerando as diretrizes iniciais sobre a concepção da performance. No teste realizado (no dia 22/4/2018) experimentamos algumas perspectivas diferentes aproveitando a estrutura do espaço (galpão do Folias) filmando de cima, através das arquibancadas aproveitando as linhas e figuras do espaço, com a câmera em movimento, acompanhando as mudanças e transiçóes do corpo (nível baixo, médio e alto), e de frente num plano mais geral fixo.

Foram escolhidos dois espaços. O primeiro foi atrás das arquibancadas, aproveitando as linhas dessas estruturas e uma iluminação do corpo entrecortada, procurando evitar uma luz direta em foco. E o segundo, o corredor atrás da cortina do palco, colocando um foco de lado de uma das saídas. A performance foi realizada em uma dessas saídas e filmada desde o fim desse corredor. em um primeiro momento realizei duas versóes seguidas inteiras da performance focando na gravaçấo do áudio e para ter uma ideia dos trajetos do movimento e da voz. Logo repeti alguns fragmentos, explorando mais a parte inicial e a parte final. Por último foi gravada a performance inteira novamente no segundo local escolhido. Da última versão não utilizamos nenhuma imagem, por considerarmos que havia pouca luz no local.

\section{Outras vozes, observaçóes da equipe de trabalho do vídeo:}

QUANDO VOCÊ FAZ COLABORAÇÃO VOCÊ DEIXA SEU TERRITÓRIO PARA PERMITIR QUE UM TERCEIRO TERRITÓRIO ACONTEÇA. ESSE É UM DOS PRINCÍPIOS DA COLABORAÇÃO.(MONK, 2014: P.97)

106 When you do a collaboration you let go tory so a third thing is allowed to happen. That is one of the principles of collaboration.
Abrir o Galpão é sempre um desejo: esta caixa vazia e torta que só tem sentido quando tem gente dentro dela. Espaço grande e constantemente habitado por espetáculos de teatro que ocupam quase tudo e mais um pouco.

Através do trabalho nesta caixa preta constrói-se um beco. Um beco de luzes recortadas no corpo, um corpo que não é bem um corpo, mas uma expressão que aparece e some na penumbra. O som que dele sai é un canto dos órgáos internos, das ca-

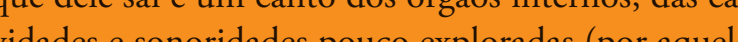
vidades e sonoridades pouco exploradas (por aquele no qual a voz é coisa que saí do cérebro e vem para boca, lembrada corpo só quando falta)

O corpo encolhido no cháo é a pulsação de uma voz, que se levanta, se expande e depois se recolhe, deixando no espaço os vestígios desta expressão. Como quem adentra lentamente em um corredor que leva a um beco escuro e profundo, olha o que lá dentro pulsa, pulsa junto, sente, e depois se retira ofuscado pela luz do dia.

\section{Documentarista e editor Caetano Tola:}

Nos últimos anos já havia acompanhado algumas apresentaçóes do solo de Inés Terra num momento em que se sobressaia o trabalho como de poesia sonora. Pude nose sobressara o trabalho como de poesia sonora. Pude notar, assistindo ensaios, todo o processo que encorpou o solo vocal construindo um trabalho consistente de corpo e voz. Quando fui convidado para fazer o vídeo junto com Lucas não fazia muita ideia de como poderia funcionar.

Ao irmos estudar a locação onde gravaríamos ficamos preocupados. O teatro em que iríamos estava todo arrumado com um cenário onde tudo era claro, luminoso bege, nada podia ser mais antagônico ao que queríamos. A dificuldade com esse cenário fez com que buscássemos alternativas que já estavam no próprio propósito de ser da performance. Fomos encontrar "bueiros" nos bastidores do galpão e fomos parar na parte de trás das arquibancadas. Terminamos por filmar por entre as ferragens da estrutura de maneira que pudéssemos intercalar os movimentos do corpo com barras, pilares e sombras compreendendo esses elementos como parte do corpo da Inés. Encontrar esse espaço diante da dificuldade de se confrontar com usse esrio que náo era de nosso agrado dissolveu a dúvida de qual 
seria o papel do vídeo ali, deveríamos ser de fato o bueiro, a mirada do bueiro. Foi esse olhar do bueiro que veio a pautar, então, a filmagem e o processo de edição, seja adicionando elementos gráfcos ou buscando sempre o corpo como uma extensão desse bueiro audiovisual."

Compositora e editora de som Julia Teles:

"Quando fomos gravar a vídeo - performance Una Mirada desde la Alcantarilla, eu não sabia se nosso sistema seria totalmente eficaz para captar esse som de um corpo em movimento. Optamos por um microfone do tipo lapela, muito usado em filmagens justamente por ter um transmissor e receptor de radiofrequência, o que permite que o ator (ou no caso, performer) se desloque mais livremente. Uma preocupaçáo que eu tinha era de que podíamos captar muito ruído das movimentaçóes da roupa, caso houvessem movimentos bruscos. Como a performance se trata mais de uma fluidez do que de inpacto, conseguimos gravar de forma satisfatian com pomém um gravador da marc Zoom, fixo, para captar o som no espaço, para "garantir" a gravaçăo, caso houvesse problemas com o lapela. Ao mesmo tempo que esse método capta mais sutilezas e frequências agudas, acaba captando mais ruídos da rua e ambientes. São duas formas de captação opostas, uma muito próxima da fonte sonora (o corpo) e outra mais distante e dispersa, captando também todos os arredores. Esse tipo de captaçáo com microfone de lapela gera um som bem pouco natural, muito grave e com pouca definição aguda, porém o que fizemos na pós-produção foi equalizar para trazer mais agudos e amenizar os graves, e colocar lizar para trazer mais agudos e amenizar os graves, e colocar
um leve reverbe nesse canal, para deixar sua projeçáo mais um leve reverbe nesse canal, para deixar sua projeçáo mais natural, como se estivesse mais inserido no espaço. Usamos
ele somado ao som estéreo do gravador Zoom, pois assim ele somado ao som estéreo do gravador Zoom, pois assim
trouxemos um pouco da naturalidade do ambiente de funtrouxemos um pouco da naturalidade do ambiente de fun-
do e as reverberaçôes reais do espaço. Foi interessante que com poucos equipamentos (um gravador estéreo e um microfone de lapela) conseguimos captar várias nuances das emissóes sonoras da Inés (respiraçōes, sons graves, som das movimentaçóes, entre outras coisas), e conseguimos gravar de uma maneira satisfatória.

Documentarista e editor Lucas Ogasawara:

"Venho de uma História e de um processo de memória onde o cotidiano monótono e opressor imperava sobre as vontades e as realizaçóes, o que sempre me fez pensar na utilidade dos sentidos para além do sensorial (aquilo que sinto por meio deles). Através das partes sensoriais que ca- bem do meu corpo para dentro de mim (ou seja, depois do ver, ouvir, tocar, etc), aprendi a diversificar os significados já que o meu entorno náo permitia. Assim, percebo o mundo pelo diálogo multidisciplinar, onde não há uma separaçáo sensorial e muito menos discursiva ou narrativa: sentimos tudo porque estamos nos corpos que foram nos dados. Não há apenas som para um cego, há também imagem mesmo que nada se veja. $\mathrm{O}$ mesmo para o som, que possui sim o poder de distribuir olhares, toques e outras definiçôes do sensível. Na realizaçāo dessa obra, muito foi me dito para considerar o distanciamento entre corpo, imagem e som como ato provocativo, e mesmo encontrando em mim resistência a essa desconexão, registrei a performance pensando estar fazendo isso. Porém, acredito que na captaçáo falhei por falta de compreensáo sobre o processo da autora. Já na ediçäo, processo que me sinto a vontade por ter tora. Já mais de 20 anos de experiêcia pratica, pe voitio desprezo à provocaçáo da autora e cai em uma montagem aparentemente documental, recheada de trucagens invisíveis ao olhar e pouco sensíveis ao restante dos sentidos. É a minha forma de desconectar imagem e som. Não pelo resultado gerado, pois o corpo humano é ignorante de si mesmo e acaba sucumbindo as suas próprias ilusōes, mas por saber que o processo de diálogo multidisciplinar é construído, e o poder narrativo é instaurado pela percepçáo de cada um, o que gera em certos momentos a noçáo de dissociaçáo sensorial proposta pela autora. Há edição onde não se observa ou escuta, há monotonia onde parece haver mo se observa ou escuta, há monotonia onde parece haver montagem. Há divisāo da imagem, há recorte, câmeras lentas e aceleradas apagamentos e reconstrução do corpo da autora. Foi uma experiência enriquecedora não apenas por aprender mais sobre mim através do trabalho dela, mas por permitir que houvesse diálogos para além do discursivo e justificado, em instâncias sensoriais e afetivas."

\section{Roteiro vocal para o vídeo:}

_Sons guturais: $[\mathrm{H}]$ epiglotal surdo fricativo, modificaçóes do trato vocal. Sons graves. Movimento interno. Respiraçóes sonoras.

_Sons vibrantes. [R] uvular ligado aos sons nasais, logo orais a partir das vogais.

_Repetição desses ciclos (R uvular - som nasal - vogais) com vibratos, variaçốes de registros, fry e drive.

_Desdobramentos das repetiçóes. Sons lisos que viram estriados e sons estriados que viram lisos.

_Golpes de epiglote 


\section{_Sons polifônicos: sons aspirados atacados no agudo.}

\section{Roteiro inicial com a movimentaçáo para o vídeo:}

_Chão. Mãos nos joelhos, cabeça nas pernas. Ísquios nos calcanhares. Sons guturais que ressoam dentro da boca com modificaçôes do trato vocal (forma da boca e palato mole). Movimentos do pescoço para um lado e para o outro em cada expiraçáo, para a frente, sem sair do cháo, assomando o olhar. Sentir a vibraçáo desse som vocal no peito, no chăo, nas costas.

Saindo do chão, cabeça e tronco. Aos poucos deslizo as mãos nas pernas enquanto expiro. O olhar sobe, mas continuo ligada ao chăo. Os sons se desdobram junto com os movimentos. Afundo o esterno na inspiração, enrolando a coluna e levando os cotovelos para afora do corpo. A inspiração é também propositalmente sonora, por vezes nasal, por vezes oral com modificaçáo do trato vocal e variaçōes de formas vogais. Durante a expiração alongo a coluna, elevando a cabeça e voltando os cotovelos para perto das costelas. Nesse processo as mãos passam pelas pernas, virilhas, estômago, logo costelas, levando novamente os cotovelos para afora do corpo e deixando as mãos encostarem no ar ao redor do tronco. Aos poucos os braços se abrem, é uma nova perspectiva, ainda no chão.

_R uvular - a u i [oral] - Enquanto desenho vocalmente a transição entre a textura mais ruidosa [R] e a textura lisa [a u i] da voz esculpo com as mãos formas análogas. Aqui começa uma parte onde a movimentação é produzida a partir da fisicalidade do som; a tensão entre o corpo que a voz produz e a voz que cria o corpo. Há um caminho para chegar em pé, sem perder esse centro, a ligação profunda com o chão.

_Movimentos dos braços e do centro do corpo me empurram para cima e para a direita, numa força em espiral.

\section{_O corpo se dissolve junto com o som polifônico.}

Após a gravação do vídeo continuei os ensaios regulares no intuito de aprofundar as relaçóes entre o movimento do corpo e as vozes, e no intuito de me prepara para a reestreia da performance no Centro de Referência da Dança (20/10/2018).

Ao trabalhar o movimento do corpo a partir dos lugares de ressonância das vozes e da minha pesquisa em dança, a peça ganhou outros tempos. Me refiro ao movimento que continua o som vocal e ao som vocal estimulado pelo movimento. Me refiro à importância dos silêncios e à diferença entre os tempos de um corpo em movimento e suas vozes, e à junção e contradição entre estes. A peça foi configurada em três atos. No segundo ato foram acrescentadas vozes pre - gravadas, como uma paisagem vocal externa. Durante a performance vocalizo junto com as vozes gravadas.
Ao acabar a intervenção das vozes gravadas, a movimentação é ainda pautada pela memória das mesmas, apresentando resquícios e respostas, tanto no movimento do corpo como nas vozes ao vivo. No primeiro ato as vocalidades conduzem o movimento do corpo (no chão) com impulsos de sons graves sem vibração de pregas vocais. No segundo ato fico em pé e realizo uma movimentação em diagonal a partir dos pés e dos braços, enquanto alterno intervençóes vocais que complementam as camadas de vozes pre-gravadas que apresentam uma harmonia definida sobre a qual improviso com sons ligados que vão se desdobrando em diferentes técnicas vocais/efeitos. No terceiro ato contínuo a movimentação do segundo ato ocupando o espaço de forma mais livre, lembrando das vozes que passaram, alternando momentos em que estas reverberam no corpo em movimentos e em que as vozes são novamente produzidas. Aos poucos vou trabalhando com o peso do corpo, a ideia de descontrole, como numa briga de forças internas e externas, realizando impulsos iniciais que se desdobram em movimentos não programados. Esse momento vai diminuindo a sua intensidade e as intervençōes no espaço até chegar no microfone. No microfone fico respirando um tempo até a respiração ficar mais lenta e realizar sons aspirados multifônicos atacados na região aguda da voz. 


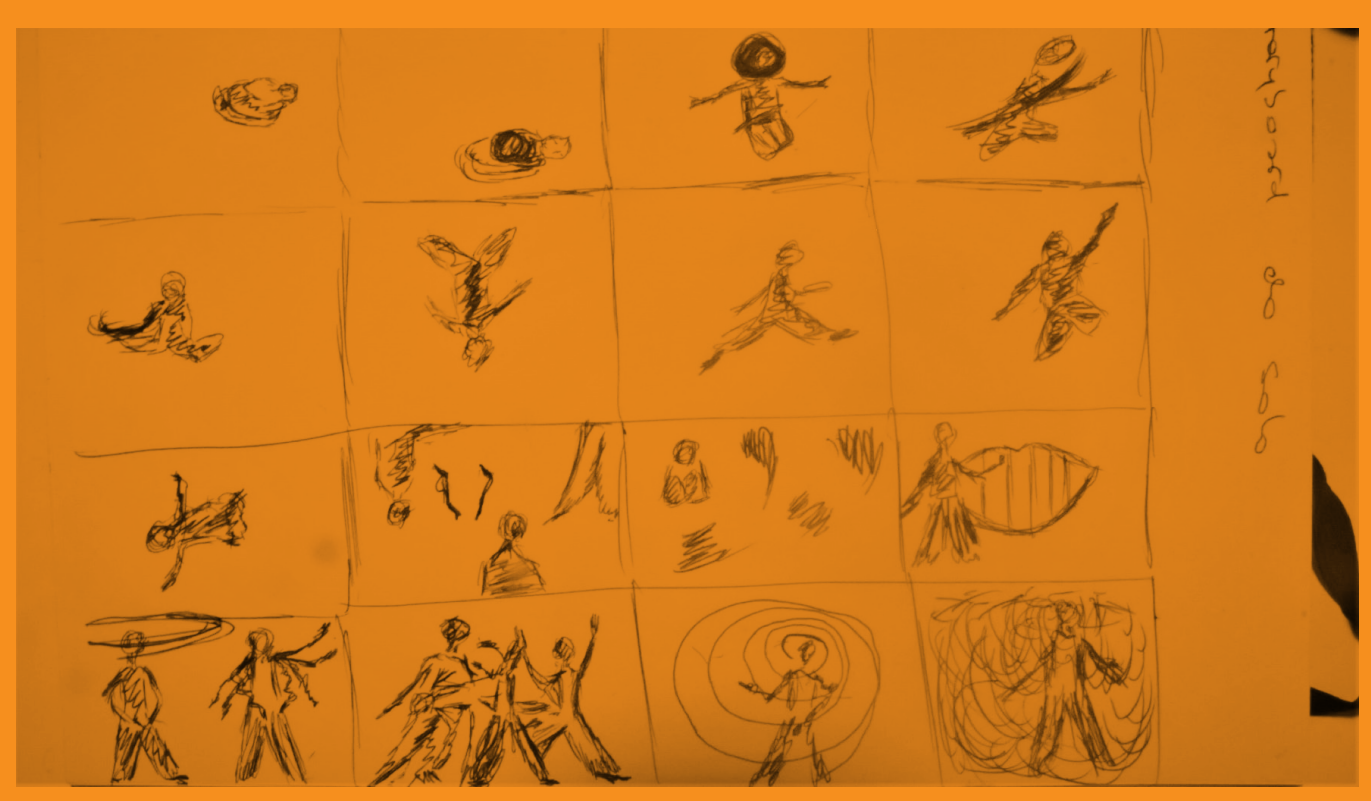

Storyboard do solo, realizado no dia 12 de março de 2019 na Casa Líquida. Este não possui um mapa de movimentação exata do solo, mas é o acúmulo de certas imagens que se encontram presentes enquanto danço.

A partir do fim de janeiro de 2019 comecei a ensaiar duas vezes por semana na Casa Líquida, em São Paulo. Julia Feldens mora na Casa Líquida e abre as portas da mesma para diferentes artistas desenvolverem seus trabalhos. O projeto de Feldens começou como um processo que ela chama de "abrir o claustro", uma performance de longa duraçáo baseada no entendimento de que ela e seus filhos possuem um corpo que se transforma junto com a casa (outro corpo) mediante as partilhas diárias. Esses corpos se configuram a partir do que acontece na interaçáo e troca cotidiana com artistas que entram na casa, realizam suas pesquisas e criam junto com Feldens modos de troca náo pautados no dinheiro. $\mathrm{O}$ projeto começou como uma experiência muito aberta e hoje faz parte da pesquisa de mestrado da artista, investigando também outras economias possíveis para o que é produzido na Casa e entre as artistas.

\section{O CORPO DA VOZ/A VOZ DO CORPO107}

A distinção sexo/gênero é um dos marcadores sociais mais fortes. ${ }^{108} \mathrm{~A}$ voz como parte do corpo adequa-se ao contexto e às suas demandas sociais. $\mathrm{O}$ som da voz ressoa no nosso corpo e fora dele, mas os limites da voz são difíceis de definir. A voz é capaz de criar outros corpos, desafiar esses processos de adequação e criar outros paradigmas. No trabalho da pesquisadora Dordete Jacobs (2015) sobre a queerizaçãa $0^{109} \mathrm{da}$ vocalidade em performance, ela aponta que:

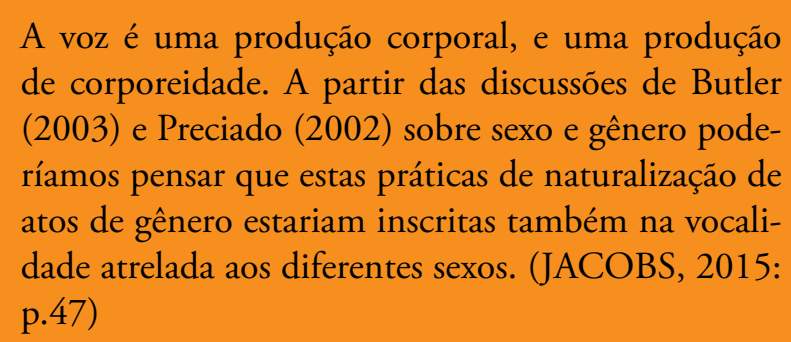

$107 \quad$ INÉS: Nota (MONK in FALBO, 2014) $108 \quad$ Anne Karpf sociológica da produção vocal e da relação da voz com a diferença sexual. Ela explica que nem todas as diferenças entre cozes femininas e mascadas pelas alterações da puberdade: "cada cultura estabelece para os dois sexos normas e convenções contrastantes que vão além das diferenças biológicas.
(JACOBS, 2015: p. 59)

109 Nesse contexto, um corpo vocal queer um corpo vocal potente na materialização de sua corporeidade afetante e desestabilizador das naturalizações de vocalidade e gênero em cena. queer/estranho no. corpo vocal não precisa fixas de gênero, mas ao entre, aquilo que não se nomeia, um corpo vocal em devir, que está em transformação, devir queer. (JACOBS, 2015: p.104)
Há uma relaçáo entre a voz e o corpo/imagem quando é presenciada uma performance, e mesmo quando se trata da escuta de uma gravação. Espera-se deste corpo que se apresenta para nós, uma voz com características específicas que desenhamos a partir da imagem do corpo, entendida a partir de definiçôes contextuais fundamentadas na diferença sexual e em padrōes comportamentais definidos pelo lugar que esse corpo/imagem ocupa na sociedade. Segundo Paul Preciado, o sistema sexo/ gênero é uma inscrição que liga os órgãos reprodutivos à sexualidade, determinando uma série de naturalizaçôes e binarismos que se referem a uma construçâo social.

$$
\begin{aligned}
& \text { O sistema sexo/gênero é um sistema de escritura. } \\
& \text { O corpo é um texto socialmente construído, um } \\
& \text { arquivo orgânico da história da humanidade, como } \\
& \text { história da produçấo - reproduçáo sexual, na qual } \\
& \text { certos códigos se naturalizam, outros ficam elípticos } \\
& \text { e outros são sistematicamente eliminados ou risca- } \\
& \text { dos. (PRECIADO, 2002: p.26) }
\end{aligned}
$$

A partir do momento em que esperamos de um corpo em performance uma açáo definida por uma série de pressupostos (ideias), inevitavelmente intervimos na mensagem poética cujas motivaçôes são sempre de reciprocidade.

Se atribuímos um sentido a alguma coisa presente, isto é, se formamos uma ideia do que essa coisa pode ser em relaçáo a nós mesmos, parece que atenuamos inevitavelmente o impacto dessa coisa sobre o nosso corpo e os nossos sentidos. (GUMBRETCH, 2004: p.14) 
Atenuar o impacto é "ter controle" sobre alguma coisa. Imaginemos uma artista em cena, embaixo de um foco de luz. A plateia se encontra lotada, o público vê, mas neste caso não é visto. É como se o público estivesse no panóptico, porém a artista sabe que está sendo vista [se prepara para isto] e é nessa percepção que a performance se faz possível. Ao ter consciência de ser vista, a artista se dirige a um outro, mesmo quando se tratar de uma performance silenciosa, embora invisível aos próprios olhos nesse caso.

A partir do momento em que a voz se faz presente, ela entra no embate com a ideia preestabelecida desse corpo/imagem. Se a açáo quebra com a ideia preconcebida a partir do corpo imagem, então o impacto é inevitável. Somos olhados, mas dificilmente esse olhar é recíproco, no entanto, a escuta é sempre recíproca, a voz se dirige sempre a um outro, "conexão plural de bocas e ouvidos" (CAVARERO, 2016). Se o corpo é um texto ${ }^{110}$ (visual), a voz pode ser a sua fuga (sonora):

a voz é um fenômeno queer, visto que gera um terceiro espaço entre quem vocaliza e quem ouve, operando como mediadora entre corpo e linguagem, que para Jarman-Ivens sáo espaços engendrados. As-
sim, a voz é capaz de transpor e desestabilizar estes engendramentos. (JACOBS, 2015: p.148)

A partir da exploração vocal se inicia um trânsito intencional entre o corpo e a linguagem. A voz, criadora de outros corpos e espaços, afirma um eu fluido. Algumas das frases mais recorrentes que surgem nos processos de estudo das vozes são: "que voz é essa?”, "não parece comigo!". Mesmo quando não há uma intencionalidade voltada para essa ruptura da imagem do corpo e/ou a afirmação da voz como um fenômeno queer, o desconhecimento é constante. A escuta da própria voz é sempre inusitada.

Demetrio Stratos explica que expressa seu componente feminino através do que ele chama de "som original, a voz" (EL HAOULI, 1993). Logo, Stratos mostra uma percepçáo do gênero como uma construção ao responder:

\begin{abstract}
Na sociedade e na cultura ocidental, a audácia, a agressividade, o valor, a violência, são considerados masculinos; outros, como a ternura, a submissão, capacidade de compreensáo, a doçura, como femini-

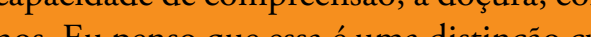
nos. Eu penso que essa é uma distinçăo cultural, que são artificialmente exaltados na mulher e no homen alguns valores em detrimento de outros, embora se trata de um patrimônio comum a ambos. (EL HAOULI, 1993: p.85)
\end{abstract}

110 O que é preciso fazer é sacudir as tecnologias da escritura do sexo e do gênero, assim como as suas instituições. Não se trata de por outros. Não se trata nem mesmo de se desfazer das marcas de gênero ou das referências a heterossexualidade, mas sim de modificar as posições de enunciação.

Sendo exaltados alguns atributos determinados como corpos - homem e corpos - mulher, a busca por uma adequação é constante. A distinção cultural binária carimba e dificulta a expressão de performatividades "outras" qualificando-as como perversas. A voz foge do texto do corpo quando não responde à tecnologia social heteronormativa, como define Paul Preciado:

esse conjunto de instituiçoes tanto linguísticas como médicas ou domésticas que produzem constantemente corpos - homem e corpos - mulher. No âmbito do contrato contrassexual, os corpos se reconhecem a si mesmos náo como homens e mulheres, e sim como corpos falantes. ${ }^{111}$ (PRECIADO, 2002: p.21)

Reconhecem lidade de aceder a todas as práticas significantes, assim como a todas as posições de enunciação, enquanto sujeitos, nou como masculinas, femininas ou perversas." (PRECIADO, 2002: p.21)

112 INEÉS: Sobre este assunto, há diferenças entre a metodologia de canto erudito francesa, italiana e alemã. No estudo da voz na músic popular, esse entendipossibilidade de transposição de uma tonalidade para a outra, e por ter nesse universo uma maior abertura aos diferentes tipos de emissão vocais que evidenciam a unicidade das vozes, modos por exemplo de atingir uma nota muito aguda. Embora também gadas às suas respectivas heranças estéticas segundo o estilo, e embora não se trate de música escrita, mas sotransmissão oral, ainda na pedagogia vocal da música entendida como popular, a classificação vocal se faz presente na maior parte dos exercicios dados.
Em detrimento da participação das mulheres como cantoras nos teatros e outros espaços, do século XV ao século XVIII homens eram castrados para impedir o desenvolvimento hormonal que modifica a voz destes na passagem para a adultez para estes atingirem uma voz não humana, ideal. Procurava-se na voz o som dos deuses a partir da castração. Ao mesmo tempo, "esse mesmo corpo com essa voz angelical despertava desejos sexuais em mulheres e homens” (BECKER, 2009). Para atingir uma voz "outra" era necessária a assexualidade, já que na perspectiva da época, a materialidade dos órgãos reprodutivos produziria sempre corpos homem ou corpos mulher. Com o fim dos castrati e a afirmaçáo do pensamento cartesiano "as vozes passam a existir como femininas ou masculinas e acabam por ficar refém da moral burguesa vitoriana" (BECKER, 2009)

Os corpos são determinados pelos códigos fundamentados na dualidade sexual para garantir a sua inserçáo heteronormativa no mercado e na cadeia reprodutiva. Desta maneira, a nossa visão de corpo é diretamente entendida a partir de certas normas institucionais binárias, ligadas às noçóes de sexo e de gênero, às suas funçôes reprodutivas e consumidoras, e por consequência, também à escuta de vozes devastadas por essas normas e códigos. Pensar as vozes sempre atreladas aos órgãos reprodutivos é equivalente a entender a sexualidade sempre restrita aos mesmos. Nessa concepção, outras partes do corpo, não reprodutoras, não seriam sexualizadas, e as suas vozes, sempre perversas.

As classificaçōes vocais ${ }^{12}$ (soprano, contralto, barítono, tenor, baixo) que conhecemos a partir da cultura do canto erudito, seguem a ordem da diferença sexual como afirmadoras e delimitadoras de gênero. Essa classificação possui uma história, diretamente ligada à escrita de composiçóes para vozes específicas, e ao mesmo tempo, 
idealizadas ao longo dos séculos na música ocidental. No canto erudito a classificação vocal é fundamental pelo estudo direcionado para um recorte específico de obras. Negar que existem diferenças na fisiologia da produçáo vocal ${ }^{113}$ entre as performers seria inútil, mas desejar que o ponto de partida para o conhecimento das vozes seja outro é instigante. O horizonte é maior quando nos encontramos descobrindo o universo sonoro. A nossa escuta não é "castrada" ou delimitada pela diferença sexual. No entanto, assim como o nosso alcance visual é regulado quando crianças (na educação institucionalizada) a nossa escuta será também direcionada segundo alguns padrōes intencionais e não intencionais. Ao mesmo tempo, o ouvir não tem pálpebras e o som é parte inevitável da experiência, o que faz deste sentido um guia principal para o conhecimento e por consequência para a desestruturação de pensamentos engendrados.

A técnica do canto lírico pode ser uma ferramenta proveitosa para o desenvolvimento da voz (mesmo para quem náo deseja trabalhar com o repertório desse universo), para adquirir recursos para um bom funcionamento da laringe e do trato vocal, assim como para criar um fluxo respiratório mais consciente, porém, por que partir de um único tipo de emissão vocal, ou da classificação vocal relativa à escrita de obras para iniciar os caminhos da voz? A cantora e compositora Pamela Z (2010) $)^{114}$ fala sobre seu trânsito entre diferentes abordagens vocais, em entrevista com Tara Rodgers:

\begin{abstract}
Eu acho interessante que no treinamento ocidental de música clássica, quando você estuda com uma professora de canto lírico, elas estáo muito interessadas em ter você indo atrás do que é considerado sadas em ter vocé indo atrás do que é considerado o som cor ve - colo procto de de cor que é o modo certo de cantar. E quando voce se envolve com tipos de canto mais experimentais, ou outras visōes mais amplas, você descobre que há todas essas outras cores que você tem e pode usar -e não é certo ou errado, são apenas cores diferentes. (Z, 2010: P. 217)
\end{abstract}

As cores se localizam em práticas musicais diferentes com seus respectivos simbolismos e/ou buscas estéticas. Há diferentes cores no território da língua e da fala, nos modos de rir e de chorar, na maneira de rezar e nas procissóes, nos lamentos, nos gemidos e nos gritos, no corpo vocal instável, com seu mistério e erotismo. Esse corpo vocal regulado por inúmeros padróes de comportamento tem o potencial de descobrir emissóes que o modificam, sensibilizam e desafiam. Esse corpo vocal tem também o potencial de contestar a si mesmo e de assumir uma busca que tensiona e destrincha o que é dito através dele sem ele perceber, e o que ele realmente quer dizer. aceita sobre a produção vocal, e que dê conta de todas as explicações necessárias para a diversidade de produções vocais, tanto tidas como normais quanto como (JACOBS, 2015: p.51) $114 \quad$ Pamela Z
(1956) é uma compositora, performer e artista sonora que mora em San Francisco e trabalh com voz, tecnologias de amostras sonoras, e co ao vivo. Ela eletrônibel canto e técnicas vocais estendidas experimentais, com a palavra falada, objetos percussivos e som de samples.
(RODGERS, 2010: p. 216)
Diversos caminhos podem ser tomados para a exploraçáo de vozes que não necessariamente se definem como canto ou fala, mas como uma continuidade ou descontinuidade do corpo, perceptíveis através da escuta que envolve sensaçóes físicas de ressonância, assim como da ação da musculatura envolvida na respiraçáo. No início da pesquisa enviei um formulário para diferentes artistas que trabalham com exploraçáo vocal nos processos de criaçáo. Ao se referir aos procedimentos que as artistas abordam para a prática da exploraçáo vocal, elas sugerem:

- Barbara Togander (Argentina): Pegar as estruturas aprendidas desde sempre e desarmá-las, transformá-las, mudar a direção e a perspectiva (especialmente a perspectiva), perder o medo ao ridículo e começar a jogar com duas variantes básicas: uma técnica e uma lúdica. O lúdico, obviamente, permite que você se aproxime do trabalho sonoro de uma perspectiva que o obriga a perder o medo do ridículo: apenas deixe ir e deixe algo que você não tem ideia do que será (não pense!) que você não tem ideia do que será (não pense!), deixar que o corpo acompanhe, os braços, pernas, saltos, esticar ou a quietude exacerbada, silêncio tenso. Procure por estados de ânimo, personagens (a senhora da quitanda com essa voz estridente e aquele estado permanente de raiva, uma criança que tem muito sono e diz à máe que ela náo quer comer, etc.), procure quais outras vozes sugerem outras formas de arte como dança, pintura, literatura. Procure sonoridades nos filmes: o filme de Tarkovsky nấo tem a mesma sonoridade que o de Die Hard. Milhares de situaçôes: mil sons.

- Ute Wassermann (Alemanha): Improvisação, Memória do corpo, Escuta, disciplina pessoal, virtuosidade, contextos. Desenvolvi a minha linguagem vocal a partir da improvisaçáo e a pesquisa. Ao mesmo tempo estou escutando outras cantoras (e musicistas) de diferentes origens, ouvindo a natureza, máquinas, eletrônicos, o meio ambiente e sintonizando minha voz. Eu cos, o meio aubiente e sintoniz, no minha voz. Eu pratico os sons que atraem me interesse e desenvolvo ma memória fisica (corpo). Eu também uso notaçăo gráfica. Como produto secundário, trabalho em um catálogo sistemático (articulação, pressão do ar, ressonância) de sons vocais para compositores.

- Ligia Liberatori (Argentina): Uma técnica vocal sólida fornece ferramentas para náo se machucar e uma imensa quantidade de estímulos para investigar e experimentar. Penso que a técnica lírica é a base da minha investigaçấo. Claro que estou constantemente exposta 
- Wânia Storolli (Brasil): Meu trabalho vocal é fundamentado na prática da Respiração Vivenciada de Ilse Middendorf e também no trabalho de Corpo e Voz de Zygmunt Molik. Basicamente trabalho com improvisação vocal em conexáo ao movimento, procurando estimular a investigaçáo dos recursos da voz e a descoberta das várias "vozes" que existem na voz. A vivên. e processos corporais como a respiraçáo e o tvência de processos corporais como a respiraçáo e o trabalho com improvisação vocal em conexāo ao movim
são fundamentais para este tipo de abordagem.

- Lilian Campesato (Brasil): A primeira coisa é não esquecer que a voz é corpo e um corpo que tem uma biografia. O exercício interessante a fazer aqui é buscar os sons próprios à sua voz: os sons fisiológicos ligados a uma produçáo que tem a ver com você, com a sua voz que é úniç pra que ta a ver cón voce, con a sua voz, que é única para cada pessoa. É estabelecer um relacionamento pessoal com a sua produçáo vocal e trazer essa intimidade à tona, o que inevitavelmente se torna algo aflitivo por conta da exposição que pode gerar.

- Flora Holderbaum (Brasil): Experimentar calmamente os sons náo percebidos que costumamos fazer com a voz, como timbres roucos, tosses, chorinhos, ladainhas, pequenas enuncioçóes fáticas, expressóes sonoras onomatopaicas. Treinar "mastigar a voz" como noras on pecimento vocl com sons bem bairinos (pino) aq ir acomod vido a voz. Ouvir ar e ir acomodando a voz. Ouvir artistas vocais. Jogos de improvisaçáo livre, improvisaçóes roteirizadas gravadas, manipulação deste material sonoro gravado. Veicular o subjetivo ao poético e conversar sobre com amigos(as).

- Lea C. Taragona (Brasil): A escuta do outro e de si, experimentar ser outros, a livre improvisação.

- Phil Minton (Inglaterra): Escute tudo o que produz som, até mesmo aquele feijão ou cerveja vazia que pode cair no chão da cozinha.

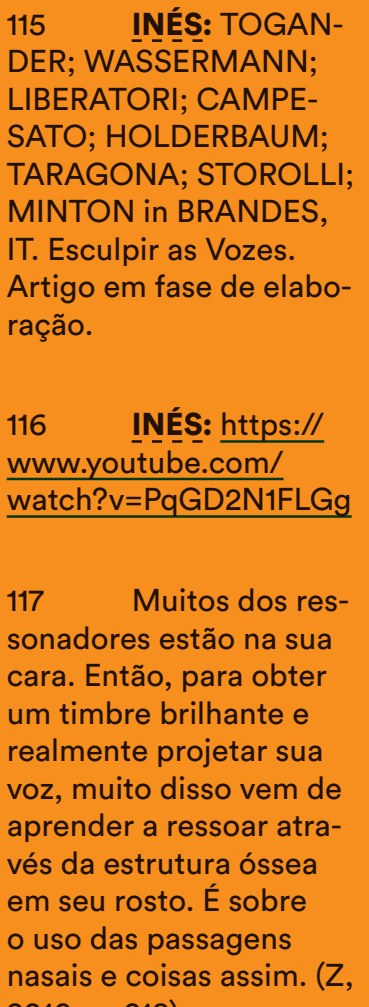
DER; WASSERMANAN: TARAGONA; STOROLLI; MINTON in BRANDES, (T. ração. watch?v=PqGD2N1FLG des materiais das vozes, pode-se estudar a fonética de uma língua não falada, como estudo de sonoridades. Ou mesmo, na própria língua, ao destrinchar seus componentes em termos de fonemas e fragmentos de palavras, abre-se um leque de possibilidades de exploração do som vocal, como se descobríssemos uma articulação muito pequena e sutil no corpo, antes náo percebida, mas que na hora de caminhar pensando nela, toda a estrutura física se modifica.

Quando estava criando Voci ${ }^{116}$, percebi que meu
canto experimental foi autodidata, e que o único
treino que eu tenho é o treinamento vocal clássico.
Percebi nesse ano que faria aulas unicamente com
cantores não ocidentais, só para ver como eles en-
sinam. E foi tão interessante para mim que haviam
muitas coisas em comum. Por exemplo, todos ensi-
navam sobre a máscara. ${ }^{17}$ (Z, 2010: p. 218)

A experimentação vocal não precisaria ser unicamente mediada por um/a mestre e/ou uma técnica específica, mas pela relaçáo constante com outras vozes, escutas e narrativas. Se entendermos a voz como corpo e realizarmos uma exploraçáo consciente dos prazeres e afliçōes do mesmo, não precisaremos que alguém esculpa as vozes ou as faça "sair do armário" da dualidade de vozes. Porém, a experiência da performance e a escuta do outro é fundamental nos caminhos da voz; a companhia e a reciprocidade dessa escuta possibilitam a invenção e fortalecem as escolhas pelos labirintos da prática vocal, inevitavelmente ligados à experiência da relação e tensão entre os corpos. A voz se forma e deforma na relação com o outro. "Escutar um outro é ouvir, no silêncio de si mesmo, sua voz que vem de outra parte" (ZUMTHOR, 2005) Quantos mais corpos sejamos capazes de escutar mais vozes serão desvendadas. 


\section{PEÇA II: A PAISAGEM VOCAL: RASTROS (2018)}

\section{https://soundcloud.com/ines-terra/rastros}

Rastros evidencia um processo que é antigo e que não se limita à composição de uma peça, mas que emerge na minha prática como cantora a medida que exploro a potência composicional da voz. O trânsito entre o que se entende como melodia e como ruído vocal, a passagem sutil entre estes e os seus limites difusos mostram uma fricçáo constante entre um modelo de beleza vocal e o prazer da descoberta de sonoridades náo pautadas na harmonia vocal, mas em uma necessidade do corpo de dizer o que antes de ser dito não lhe era permitido e/ou se encontrava oculto. Entretanto, nessa peça há uma insistência melódica que impede o ruido de se instalar totalmente, sendo forçado até o final pela harmonia já estabelecida. O ruído se apresenta sempre como um conceito relativo, considerando que ele é situado e identificado como tal a partir de uma série de associaçôes realizadas durante a escuta. Nesse caso o ruído é a contaminaçáo do contraponto modal inicial, a partir de sonoridades mais complexas que se instalam de forma gradativa nas vozes.

Em 2017 escrevi um texto para a revista de cultura eletroacústica LINDA do grupo NME, como um modo de explicar esse mergulho na voz para além da linguagem verbal e do que sempre entendi como canto.

Dizer alguma coisa sobre voz. Que não seja certeira, uma coisa solta, que tome vida e forma, sem precisa de um empurrão, de um sopro. E a voz se diz. Queria que a voz dissesse alguma coisa, em movimento. $\mathrm{Na}$ verdade, as vozes, as de dentro já conheço. Porque a gente é sempre (um pouco) o desejo do que a gente gostaria de ser. $\mathrm{O}$ que não conheço é o meu corpo. Quando era ainda uma criança, não podia gritar. É errado saturar o ambiente, as quatro paredes, ainda mais sendo mulher. Dizem. Menos paredes, mais vida? mais som? E foi assim que fui engolida. Com 27 anos comecei a dançar. Entendi que a língua que eu falava (a primeira, a segunda), nenhuma delas era a minha língua meira, a segunda), nenhuma delas era a minha língua. A minha língua era a língua do corpo, a língua do som.
Língua torta, corpo cansado, frenético, uma espécie de Língua torta, corpo cansado, frenético, uma espécie de invasão. Tanto tempo procurando a afinação que en-
volvesse o mundo, numa cancão que deitasse nas costas volvesse o mundo, numa cançáo que deitasse nas costas de quem quisesse escutar. E elas deitaram. Cançôes são bonitas, são como rios. Mas o corpo falou uma outra lingua. Percelo que a respiraçao era una música, a mais realista delas. Dei para a garganta o que era da
garganta, deixei o pulmấo apitar sem dor. Devolvi o meu sacro para a terra e deixei o meu palato brincar com as nuvens. Mas ainda, da voz, nada sei. Quando alguém quiser cantar para você, agradeça. Agradeça o grito, a lembrança, o fio, o apito, a rouquidaso, o grito, a lembrança, o fio, o apito, a rouquidão, o fogo, o peso, o ruído, a multidáo. Agradeça nada. Talvez seja a última vez. Pedro falou: "vulcano silencioso", e dançamos. Muito se fala em voz, de vozes, em constante guerra com o mundo. Vozes invisíveis, cimentadas, amontoadas, apagadas ou enaltecidas. Sons articulados por altura e distância, nos corpos vibrantes. Logo se propagam no espaço. O espaço fica úmido e a distância, e a distância,...é um valo perdido. O silêncio é o modo que temos de observar o tempo, impermanente e ruidoso. Como vulcanos (silenciosos) esperamos o momento de entrar em (silupço, virar esboços de cores e calor. Todos (enerupçáa, virar esboços de cores e calor. Todos (enquanto borrós) escutamos as vozes e esculpimos a terra sem querer, sabendo que a nossa única presença possível, é a confusão, é uma queda, um tempo perdido. (TERRA, 2017) ${ }^{118}$

A melodia de Rastros (2018) nasceu como um esboço, a pedido de um amigo que estava editando um documentário. Decidi retomar a ideia inicial para trabalhar uma Paisagem Vocal. Para essa peça interessava desenhar caminhos de transformação na emissão vocal para cada uma das camadas gravadas, assim como Meredith Monk propóe em Change (faixa nove de Key). Nesse caso realizei várias escolhas baseadas na peça de Monk, a seguir:

I. Apresentar uma melodia modal ou tonal.

II. Encaminhar a composição para um lugar cada vez menos harmônico, porém sempre se remetendo à ideia inicial.

III. Escolher duas vozes com frases mais longas, movimentos melódicos com diferentes intervalos, e uma voz que funciona como um pedal.

IV. Fazer uso da nasalidade como transiçâo para o ruido vocal.

A transformação se dá do som senoidal com vibrato, ao som mais ruidoso. Foram gravadas três camadas, sendo a primeira e a segunda melodias iguais, e a terceira uma sonoridade continua que contamina as duas primeiras melodias. A peça foi gravada e mixada por mim. Gravei com um microfone condensador e utilizei um efeito de áudio de reverberaçáo e o pan para trabalhar a espacialização das vozes. As vozes começam mais espalhadas, e váo se fundindo gradativamente a medida que a melodia vai se perdendo. As três vozes se transformam em termos de sonoridade ao longo da peça. As primeiras duas vozes partem de uma emissão mais coberta com vibrato, aos 
poucos se tornando mais ruidosas, por meio da nasalidade e da soprosidade, perdendo seu caráter harmônico, seu local individual, se unificando gradativamente. A medida que as vozes se aproximam a partir do ruído, formam uma massa sonora única.

A voz I é uma melodia em mi menor eólio que possui três frases. A entrada da voz II acontece em um segundo momento, começando na terceira frase, se entrelaçando em um outro ritmo e sincronizando em alguns momentos, harmonizando e criando também alguns uníssonos. Não desejava estabelecer um tempo fixo nem um movimento espelhado entre as vozes, mas possibilitar pontos de encontro sempre diferentes. A terceira voz é uma nota mi ligada que se instala quando foram apresentadas as duas primeiras exposiçôes da melodia principal. A voz II demora um pouco mais em chegar ao ruido, apresentando uma emissão vocal suave com bastante ar, a invés de passar pela emissão nasal como transição para emissão mais gutural. A voz III transita entre " $m$ " e "n" com o movimento da língua, evidenciando a mudança de harmônicos. Em seguida acrescenta a sílaba "gang" que repete de forma ligada. Esta voz já no início possui um espaço de ressonância maior do que as exposiçôes da melodia original e emerge nos dois canais, invadindo tanto a primeira como a segunda voz.

\section{Exploração vocal}

Para quem estuda a voz em função de determinado repertório ou estilo musical a experimentação vocal não é tarefa fácil. A procura por uma fidelidade em relação a um tipo de emissão vocal pressupóe um estudo baseado em modelos e padrões específicos. A exploração vocal pode ser uma tarefa "controlada" e de profunda vertigem, considerando a dificuldade de abandonar o lugar conhecido, para a descoberta de outras vozes. Ao mesmo tempo, cada território e/ou estilo musical apresenta uma flexibilidade específica para certas sonoridades vocais e tem muito a acrescentar no repertório da performer criadora.

Considerando que a memória muscular e da escuta possibilita o desenvolvimento técnico e criativo, como deixar em um segundo plano os padróes de beleza vocal e os parâmetros musicais para adentrar na experimentação e descobrir outras vozes? Como pensar composição a partir da experimentação vocal?

Nos processos de exploraçấo vocal da performer criadora, a voz deixa de ser pensada e escrita unicamente pela compositora para ser investigada também por quem vocaliza, a voz se escreve a si mesma durante a performance. Ao mesmo tempo, como som que ressoa no corpo para logo se projetar no espaço e transcender o mesmo, ele é suscetível à manipulaçáo mediante ferramentas externas. A voz ressoa no próprio corpo e se propaga no espaço, gerando dois tipos de escuta simultâneas.

Quando se fala de exploraçáo vocal, fala-se inevitavelmente de improvisação, considerando que só mediante a experimentação e através de um desprendimento dos hábitos vocais, consegue-se desvendar outras vocalidades. Segundo a contrabaixista e improvisadora Joelle Leandre, "improvisar é se encontrar entre dois mundos, onde nada é certo mas tudo é possível" (FRANCK, 2011) ${ }^{119}$. Os idiomas fazem parte do repertório da improvisadora, mas estes aparecem e se desfazem no tempo, a partir da experimentaçáo e da busca constante em tempo real. Para Joelle, a improvisadora "não se prepara para a improvisação, se prepara para um vazio, para

119 To improvise is to find oneself between
two worlds, there where
nothing is certain but nothing is certain but everything is possible.
(FRANCK, 2011: p. 9)

120 You don't prepare an improvisation, for the emtiness, for the flux, the energy we send each other on stage". (LEANDRE in FRANCK, 2011: p. 70) o fluxo, a energia que é compartilhada durante a performance" (FRANCK, 2011) ${ }^{120}$. A partir da experimentação vocal fazemos descobertas técnicas que não foram diretamente procuradas. Aos poucos é criado um repertório de sons e seus modos de articulação mais intencional.

Mesmo numa experiência solo, a performer criadora se depara com materiais sonoros desconhecidos e pode eventualmente voltar para estes, como se volta a um movimento do corpo que não foi coreografado, mas que fica na organicidade 
psicomotora daquele momento. A descoberta da multiplicidade de qualidades vocais produz em princípio a experiência de habitar diferentes corpos e de escutar sonoridades que revelam outros imaginários possíveis. Isto se relaciona com o que o pesquisador Rogério Costa escreve em seu livro "Música Errante" (2016) quando se refere ao corpo e ao prazer da performance, no caso, durante a improvisação livre:

Quando falamos anteriormente sobre "os efeitos da performance em tempo real no próprio corpo dos músicos e as afetividades ativadas antes e durante a performance", pensamos em algo muito forte, ligado à noçáo de prazer físico e lúdico que percorre, como um vetor de vital importância, toda prática de improvisaçáo. A relaçáo com o instrumento, [...], a improvisça A relça com o instrumento, $[\ldots]$, a duzido, a possilidade de manipulaçáo, o praz produzido, a possibilidade de manipulaça, o prazer da enunciaçáo, da expressáa, tudo isso gera uma espécie de "gozo". (COSTA, 2016: p. 181)

Descobrir modos de vocalizar é também descobrir outros modos de se relacionar, modos de dizer o incomunicável; modos de transmitir experiências do corpo năo nomeadas. O que Costa chama de prazer motor pode ser entendido como a percepção de um corpo sensível, que é agente e, ao mesmo tempo é habitado e marcado pela ação de tudo o que o rodeia. Se é a partir da respiração, dos sentidos e das emoçóes, que fazemos parte de uma espécie de textura viva, o movimento das vozes do corpo é uma resposta contínua a essas relaçóes:

$$
\begin{aligned}
& \text { O prazer de dar uma forma própria às ondas sonoras } \\
& \text { faz parte da autorrevelação vocalizada. A emissão é } \\
& \text { gozo vital, sopro acusticamente perceptível, no qual } \\
& \text { o próprio modela o som revelando-se como único. } \\
& \text { (CAVARERO, 2011: p.19) }
\end{aligned}
$$

Entender a emissão vocal como gozo ${ }^{121}$ é também um processo de aceitação e descoberta, e de revelação de repressóes, já que a voz se encontra intimamente ligada aos processos emocionais e psicológicos da experiência. No teatro antigo grego a exploração de vozes era incorporada como um modo de se livrar de males e doenças do corpo:

$\mathrm{Na}$ tragédia grega, buscava-se gerar o sentimento

de verdade no público, permitindo a este purgar-se

de verdade no público, permitindo a este purgar-se
de algum mal. Ela estava diretamente associada aos

males do espírito, e do corpo físico, quando afetado

pelo espírito. Um dos códigos de linguagem capazes

de promover isso era a voz. (VARGENS, 2013: p.5)

A pesquisadora Sally Banes (1983) menciona algumas artistas que influencia- ram o Judson Dance Theater no início do mesmo, levando propostas para os processos de criação em dança, e/ou apresentando algumas performances para o grupo. Uma delas é a artista Anna Halprin. Segundo Banes (1983), Halprin levou para o Judson "a liberdade para seguir a intuição e o impulso durante a improvisação."

Ao procurar mais informaçóes sobre a artista, encontrei um vídeo de uma performance realizada por Halprin em 1975 em Paris (França). O título do solo é Dancing my cancer. ${ }^{122}$ Halprin tinha sido operada de câncer algum tempo antes da performance e a doença tinha voltado a se manifestar. A artista decidiu fazer um trabalho/ritual em relação a essa situação, vestindo um pano preto, dançando e vocalizando visceralmente para um desenho feito por ela mesma em representação também da doença.

A exploração vocal pode-se pensar para além do significado das palavras e dos parâmetros musicais, para adentrar em um processo de experimentação da materialidade do som. No entanto, desvencilhar essa materialidade do contexto é uma tarefa questionável, considerando que o som é também um elemento cultural e simbólico. Nesse sentido, é possível realizar uma investigaçáo dos recursos sonoros da voz a partir de qualidades simbólicas da mesma, pensando, por exemplo, em intencionalidades de expressão ou processos de tradução de imagens, memórias, textos e outras referências não necessariamente sonoras. A exploração vocal propicia um ambiente em que convivem os ruídos possíveis, as melodias simultâneas, a harmonia e a inarmonia ou, segundo o Cage, a harmonia anárquica.
$121 \quad$ Assim, a voz, utilizando a linguagem para dizer alguma coisa, se diz a si própria, se sença. Cada um de nós pode fazer a experiência do fato de que a voz, independentemente daquilo que ela diz, propicia um gozo. (ZUM
THOR, 2005: p. 63)

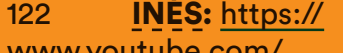




\section{Técnicas Estendidas da Voz}

Em When Words Are not Enough (2008) a pesquisadora norte-americana Melanie Crump define as técnicas estendidas da voz como: "Um corpo de práticas transportado pelos métodos náo-tradicionais da produção vocal, possivelmente alterando o timbre natural ${ }^{123} \mathrm{da}$ voz com o propósito da expressão musical"(CRUMP, 2008: p. 3) $)^{124}$

As pesquisas referidas às técnicas estendidas da voz têm crescido bastante a partir da segunda metade do século XX na área da música. Se entendermos o estendido como práticas não aceitas em determinado contexto, partiremos da observação da voz e de como esta age em cada ambiente. Mais especificamente, o que seria entendido como não-convencional em um ambiente de música tradicional de concerto europeia, na música andina sul-americana poderia ser o modo de emissão cotidiano. Isto quer dizer que a definição desse termo é sempre culturalmente situada e portanto relativa. O termo é utilizado para definir técnicas vocais não usuais, derivadas da exploração do aparelho fonador e da utilização de suportes tecnológicos como pedais ou computadores que transformam o som em tempo real, funcionando como figurinos vocais.

No âmbito da música ocidental, o que se entende por técnicas estendidas da voz é continuamente associado a um lugar de ruptura das artes hegemônicas do século XVIII e XIX, com as vanguardas (Cubismo, Futurismo, Dadaísmo e Surrealismo) do começo do século XX. Para descrever estas influências, Crump sintetiza:

$$
\begin{aligned}
& \text { O cubismo e o Futurismo apresentaram para o mun- } \\
& \text { do o conceito de colagem, o Dadaísmo ofereceu a } \\
& \text { linguagem do non-sense pelos seus poemas sonoros } \\
& \text { e o Surrealismo proporcionou um sonho como at- } \\
& \text { mosfera capaz de sustentar sons bizarros. (CRUMP, } \\
& \text { 2008: p.37) }
\end{aligned}
$$

É pertinente acrescentar que os futuristas têm um papel fundamental na valorização do ruído como fenômeno estético. Deslumbrados com este novo contexto, os futuristas italianos fazem uma exaltação do aspecto sonoro maquinário, questionando as práticas tradicionais da escrita musical (como o contraponto e a fuga) e almejando "a realização do modo inarmônico" (BERNARDINI, 1980: p. 58).

Enquanto o cromatismo nos faz unica-

mente usufruir de todos os sons conti-

dos em uma escala dividida por semi-
123 INÉS: Importermo, já que a ideia de uma discussão muito presente nas diferentes áreas que estudam a voz, como a fonoaudiologia e o canto. Entendendo que a produção vocal possibilidades da mesm estariam sempre ligadas à experiência do corpo vocal e ao interesse por ir além da funcionalidade da voz no cotidiano.

124 A body of practices conveyed through nontraditional methods sibly altering the natural timbre of the voice for the purpose of musical expression. (CRUMP, 2008: p. 3)

125 Cubism and Futurism presented the world with the concept
of the collage, Dadaism offered the language of non-sense through its sound-poems and Surrealism provided a dream-like atmosphere capable of sustaining the bizarre sounds. (CRUMP, 2008: p. 37) tons menores e maiores, a inarmonia, ao contemplar também as mínimas subdivisōes do tom, além de oferecer à nossa sensibilidade renovada o número máximo dos sons determinávúmero máximo dos sons determináveis, nos permite também novas e mais variadas relaçoes de acordes e timbres. (BER-
NARDINI, 1980: p.58)

Junto a este discurso da valorização do ruído, encontramos nos manifestos futuristas, a exaltação ao militarismo e o desprezo à mulher. A sublevação (a partir das artes) era na concepção dos futuristas uma ideia restrita aos homens, e o ruído uma arma, a ser usada unicamente por estes. A ideia de ruído como poder está presente no pensamento de Murray Schafer (A afinação do mundo). Nas palavras de Schafer:

De fato, o ruído é tão importante como meio de
chamar a atençáo que, se tivesse sido possível desen-
volver a maquinaria silenciosa, o sucesso da indus-
trializaçáa poderia não ter sido tăo completo. Se os
canhōes fossem silenciosos, nunca teriam sido utili-
zados na guerra. (SCHAFER, 2001: p.115)

Segundo Crump (2008), um dos poucos documentos estruturados sobre as técnicas estendidas da voz é o Lexicon of Extended Vocal Tecniques, gravado em 1975 pelo Extended Tecniques Ensemble de San Diego. Trata-se de uma gravação que apresenta de forma descritiva as diferentes técnicas utilizadas na época, escolhidas a partir da experimentaçáo e da pesquisa do grupo. Este léxico foi gravado em fita cassete e pertence ao acervo da Universidade de San Diego (EUA). Na internet é possível acessar à gravaçáo de um concerto do ensemble, chamado Imaginary landscape, realizado no ano 1980. Recebi, por meio de Deborah Kavash, uma das fundadoras do grupo, o seguinte link: https://archive.org/details/IL $1980 \quad 12 \quad$ 19/IL $\quad 1980 \quad 12 \quad 19$ A 16. wav.

Em 1980, Kavash, cantora e atual professora de composição da Universidade de California escreveu um artigo sobre técnicas estendidas da voz no marco das pesquisas que seu grupo estava realizando. No artigo ela discorre sobre cinco técnicas principais utilizadas no seu grupo nas composiçôes. Segundo a autora estas seriam as técnicas mais usadas e mais facilmente aprendidas nesse contexto: harmônicos reforçados $^{126}$, ululação ${ }^{127}$, fry vocal, chant e multifônicos complexos ${ }^{128}$. Segundo Kavash (1980), “embora a improvisaçáo possa fornecer um contexto musical básico para novos sons e, de fato, foi o primeiro veículo de performance para essas técnicas usadas 
pelo grupo, demandas composicionais oferecem à vocalista novas dimensôes de performance".

É possível encontrar referências das sonoridades apresentadas por Kavash ou de outras antes mencionados nesse trabalho, em cantos ao redor do mundo, e inclusive na fala de diferentes línguas. Por exemplo o fry é incorporado como textura da fala no inglês. O canto difônico faz parte da expressão vocal na Ásia central, nas comunidades mongóis e tuvanas, assim como também na língua sul-africana xhosa (língua bantu nguni), ou na música dos inuites. Os clicks $^{129}$ (estalos de língua articulados na regiáo alveolar da boca), são consoantes em línguas sul-africanas, como a língua xho-

Assim como Meredith Monk menciona em diversas entrevistas, essas sonoridades podem ser encontradas na experimentação do próprio corpo vocal, mesmo sem antes possuir essas referências. Fica a questão de como estas sonoridades são in corporadas na performance. Entender que muitas das vocalidades consideradas como técnicas estendidas da voz não são novidades é importante para não assumi-las como vocalidades concebidas na prática musical ocidental. Entretanto podem ser novas para quem emite essas vocalidades pela primeira vez durante uma performance.

Se entendermos que a prática da exploração vocal parte não só de um adestramento musical ou de uma busca pela virtuosidade técnica, mas sobretudo de uma vontade de ampliar o conhecimento do corpo vocal, acessando outros espaços e prazeres do corpo, poderemos iniciar a busca de uma outra definição para estas vocalidades não usuais em um determinado contexto, um termo que destaque a complexidade do desejo deste corpo mais do que a complexidade material das vozes em si. Estas são vozes que na pulsão de atravessar o corpo, o redefinem e desafiam. Uma espécie de voracidade que dissolve a língua e o próprio corpo.
126 Os harmônicos presentes em um tom cantado podem ser individualmente reforçados ou amplificados e perce-
bidos como alturas disbidos como alturas dis-
cretas (soando como ascretas (soando como asda língua e / ou as açábio mudam a forma do trato vocal. A fundamenta cantada é produzida (...) geralmente sem vibrato para que os harmônicos possam ser ouvidos com reza também pode ser reza também pode ser nasalização, que tend a filtrar o fundamental e concentra uma maio (KAVASH, 1980: p. 2)

127 A técnica de ululação é percebida rápida e relativament uniforme do som básico. É articulada por aspirç̧ão (sopro de ar ou " $h$ ) ou quebras glotais e pode ser aplicada prasom, vozeado ou não vozeado. (KAVASH, 1980: p.5)

128 O termo "multifonicos complexos" designa vagamente um conjunto de sons produzido de forma expirada ou inspirada por uma voz. O cluster pode número de sons não relacionados por intervalo que se assemelham ao ruído, ou como uma complexa mistura de fritura vocal com outros sons ou alturas. A mistufa total pode cobrir uma som em vários níveis gerais de afinação (baixo, médio, alto) bem como em campos específicos e perceptiveis (KAVASH, 1980: p. 10). 


\section{Considerações Finais}

Um dos desafios que enfrentei durante a pesquisa foi assumir que a escuta analítica é sempre uma escuta pessoal, que combina a bagagem de uma área de estudo e suas intersecçôes epistemológicas, a vivência como performer em relação a esse assunto, e as sensaçóes produzidas em cada escuta, escuta poética que ganha continuamente novos sentidos. Por outro lado, percebo que a partir de cada uma das Notas da Voz poderia ser desenvolvida uma nova pesquisa, considerando que os assuntos apresentados requerem o estudo aprofundado de diferentes áreas de conhecimento.

Partir de enunciados de Meredith Monk para falar do seu trabalho inicial produziu dúvidas em relaçáo às escolhas bibliográficas que eu faria para desdobrar os assuntos apontados pela artista, escolhas que poderiam não estar ligadas às intençóes de Monk, mas que colocariam em foco, descobertas que revelam a pesquisa através da performance como um campo em constante expansão.

A análise das músicas do primeiro LP de Meredith Monk é inicialmente mais focada no objeto (nas qualidades vocais apresentadas), e também expandida em assuntos mais gerais. Contudo, as músicas serão inevitavelmente interpretadas segundo simbolismos pessoas e míticos que fogem da minha escrita e percepção.

Escrever sobre a própria prática é um processo complexo, a partir do qual as ideias se modificam pela constante crítica alimentada pelas leituras, pelas gravações dos ensaios, pelos retornos e apontamentos do público, e pelas colaboraçôes com outras artistas. No decorrer da pesquisa percebi que essa escrita não é só minha, que o solo nunca foi solo, que tudo o meu processo foi coletivo, seja pela parceria com outras artistas e pesquisadoras, seja pela constante lembrança e consideraçáo de outras vozes que permanecem na memória, vozes que me atravessam e desafiam a medida que elaboro o trabalho.

Desistir ou mudar radicalmente a pesquisa foram opçóes sempre latentes. Mais tarde percebi que "não saber o que acontece a continuação está na natureza da criação, e a ambiguidade do caos é algo a ser abraçado em vez do que temido."(FREEMAN, 2010) Me perguntei porque anelava tantas certezas no processo de escrita se na minha prática artística estas são continuamente derrubadas. Embora se trate de práticas diferentes, cujos processos eu me esforçava em distanciar o máximo possível, as duas práticas requerem confiança, dedicação, crítica, referências e parcerias. 
As inquietaçóes provocadas pelas performances e pela escuta de Key revelaram dois aspectos principais do trabalho: o prazer que produz o conhecimento de diferentes vocalidades, e a criação de outros corpos por meio da potência vocal, como "máscaras sonoras" que esculpem o corpo em cada emissáo, mudando a sua percepção. Acredito que essas duas questóes podem ser estudadas mais profundamente em um trabalho futuro, investigando de que maneira estas "máscaras sonoras" são elaboradas e entendidas em diferentes contextos.

\section{Referências bibliográficas}

\section{Livros e Teses}

ARTAUD, Antonin. O Teatro e seu Duplo. SP: Martins Fontes, 1999.

BARBOSA, Rosa Marilia. O canto Ancestral Negro. Resistência e Protagonismo Feminino na Cultura negro-brasileira. ECA, São Paulo, 2015.

BACKES, Laura Beatriz Backes. Voz e emoçáo: provocaçóes a partir de Wolsohn, Roy Hart e Pantheatre. Dissertação de mestrado. Universidade Federal do Rio Grande do Sul, 2010.

BANES, Sally. Terpsichore in Sneakers. Post - Modern Dance. Wesleyan University Press, 1987.

Democracy's Body. Duke University Press, 1983.

BECKER, S. A voz contemporânea. Tese de Mestrado apresentada na Eca, USP-SP, 2008. BERNARDINI, Aurora Fornoni. O Futurismo Italiano. Perspectiva. São Paulo, 1980.

BONAFÉ, Valeria Muelas. A casa e a represa, a sorte e o corte. Tese de Doutorado apresentada à ECA - USP, 2016.

BUTLER, Judith. Deshacer el género. PAIDÓS, Barcelona, Buenos Aires, México, 2006. CAGE, John. Silence. Middletown: Wesleyan University Press, 1976.

CAMPESATO, Lilian. Vidro e martelo. Contradiçōes na estetização do ruído na música. Tese de doutorado apresentada à ECA - USP, 2012.

DA CUNHA, Manuela Carneiro. Índios do Brasil: História, Direitos e Cidadania. Claroenigma. São Paulo, 2012.

CARRARA, Paula. [Corpo, Voz, Escuta] Dissertação apresentada à ECA - USP, 2015.

CASTAREDE, Marie-France. A voz e os seus sortilégios. São Paulo: Editorial Caminho, 1998.

CATANZARO, Tatiana Olivieri. Transformaçóes na Linguagem Musical Contemporânea Instrumental e Vocal sob a Influência da Música Eletroacústica Entre as Décadas de 1950-70. Dissertação de mestrado apresentada à ECA - USP, 2003.

CAVARERO, Adriana. Vozes Plurais: Filosofia da Expressáo Vocal. Humanitas, 2011.

COSTA, Rogério Luiz Moraes. A música enquanto meio e os territórios da livre improvisaçáo, Tese de Doutorado apresentada à PUC - SP, 2003.

COSTA, Rogério. Música Errante, O jogo da livre improvisaçáo. São Paulo, Perspectiva, 2016 
CRUMP, Melanie Austin. D. M. A. When words are not enough: racing the development of extended vocal techniques in twentieth-century America. A dissertation submitted to the Faculty of the Graduate School at the University of North Carolina at Greensboro in Partial Fulfillment of the Requirements for the Degree Doutor of Musical Arts, 2008.

DOLAR, Mladen. A Voice and Nothing More. Cambridge, MA: MIT Press. Londres, 2006.

FALBO, Conrado. A voz como princípio, meio e fim; uma introduçáo à poética da voz de Meredith Monk, Tese apresentada ao Programa de Pós-Graduaçáo em Letras da Universidade Federal de Pernambuco como requisito parcial para a obtenção do título de Doutor em Teoria da Literatura. 2014

EDGERTON, Michael Edward. The 21 St - Century voice. Toronto, 2004

FREEMAN, John. Blood, Sweat and Theory. Kindle Edition, 2010.

GARCIA LOPES, Rodrigo. Vozes e Visóes; Panorama da Arte e Cultura Norte-Americanas Hoje. Iluminuras, 1996.

GOLDBERG, Roselee. Performance Art. Barcelona: Ediciones Destino. 1996.

GUMBRETCH, Hans Ulrich. Produçáo de presença: o que o sentido não consegue transmitir. Contraponto. Rio de Janeiro, 2004.

HAOULI, Janete el. A escuta da voz música. Dissertação de mestrado apresentada a ECA-USP. São Paulo, 1993.

HOLDERBAUM, Flora F. PENSAR AS VOZES - VOCALIZAR O LOGOS: das possibilidades de emergência de outras vocalidades. Programa de Pós-Graduação em Música. Escola de Comunicações e Artes. ECA - USP. São Paulo, 2019.

JACOBS, Daiane Dordete Steckert. Possível Cartografia para um Corpo Vocal Queer em Performance. Tese apresentada na Universidade do Estado de Santa Catarina, Florianópolis, 2015.

JOWITT, Deborah. Meredith Monk. The John Hopking University Press. London, 1997.

GOLDBERG in JOWITT. Personal Mythologies. Meredith Monk's Education of the Girlchild, 1995. 1997: p. 49.

SIEGEL in JOWITT. Virgin Vessel. 1997: p. 39.

MONK in JOWITT. Journal Entry, January 1970. 1997: p. 30.

MONK in JOWITT. Notes on the Voice. 1997: p. 56.

MONK i JOWITT. Dreams. From Meredith Monk's Notebooks, 1978-1984. 1997: p. 113.
1997: p. 64

MONK in JOWITT. Dreams. From Meredith Monk's Notebooks, 1970-1975.
MONK; BEAR in JOWITT. A Dialogue with Liza Bear. 1997: p. 79.

SAINER in JOWITT. A Report on Meredith's Notch. 1997: p. 58.

SCARPETTA in JOWITT. Voyage to the Limits of the Voice. 1997: p. 94) 1997: p. 133.

KEY, Susan; ROTHE, Larry (Org.) American mavericks. Sao Francisco: The San Francisco Symphony, 2001

LEPECKI, André. Dance. Documents on Contemporary Art. Whitechapel Gallery and The Mit Press. 2012.

MALDE, Melissa; ALLEN Mary Jean; ZELLER, Kurt-Alexander. What Every Singer Needs to Know About the body. San Diego: Plural Publishing, 2009.

MACHADO, Regina. A voz na cançáo popular brasileira: um estudo sobre a Vanguarda Paulista. Dissertaçáo apresentada ao Instituto de Artes da Unicamp para obtençáo do título de Mestre em Música. Campinas, 2007.

MARIZ, Joana. Entre a expressáo e a técnica: a terminologia do professor de canto - um estudo de caso em pedagogia vocal de canto erudite e popular no eixo Rio - Sáo Paulo. Unesp. São Paulo, 2013.

MARRANCA, Bonnie. Conversations with Meredith Monk. New York: PAJ Publications, 2014.

MONK, Meredith. Vocal gestures (Livro de artista). Nova Iorque: Edition Jacob Samuel, 2003

MONK. Meredith Monk: Composer First”, New Music Box, New York, 2000

MEDIONI, Franck. Joelle Léandre: Conversations with Franck Medioni, Translated by Jeffrey Grice. 2011.

NETO, Caio Nelson de Senna. Textura Musical: forma e metáfora. Dissertação submetida ao Programa de Pós-Graduaçáo em Música do Centro de Letras e Artes da UNIRIO, como requisito parcial para obtenção do grau de Doutor. Rio de Janeiro, 2007.

NYMAN, Michael. Experimental Music: Cage and beyond. New York, 1973.

OLIVEROS, Pauline. Deep Listening; A composerś Sound Practice. Lincoln: iUniverse, 2005.

PIZARNIK, Alejandra. Arbol de Diana. 1962.

PRECIADO, Beatriz. O manifesto Contrassexual; práticas subversivas de identidade sexual. Madrid, 2014 
SCHLOSS, Myrna Frances. Out of the twentieth century: three composers, three musics, one femininity. Ph. D. Wesleyan University, 1993.

SCHAFER, Murray. A afinaçáo do mundo. Editora Unesp. São Paulo, 2001.

SOCHA, Alexandre. A voz e seus encantamentos: $\mathbf{O}$ fenômeno sonoro na constituiçáo do Self e no desenvolvimento humano. Dissertaçáo de mestrado apresentada na PUC. São Paulo, 2010.

SUZUKI, Shunryu. Mente Zen, mente de principiante. Palas Athena. Rio de Janeiro 1994. STOROLLI, Wânia. Movimento e Respiraçáo; A prática Vivenciada de Ilse Middendorf no Ensino do Canto. Dissertação de mestrado apresentada à ECA-USP, 2004.

VALLADARES, Leda. Cantando Las Raíces. Buenos Aires, 2000.

VARGENS, Meran. A voz articulada pelo coraçáo. São Paulo: Perspectiva, 2013.

ZUMTHOR, Paul. - Performance, Recepçáo, Leitura. Cosacnaify Portátil 27. São Paulo, 2014.

Introduçáo a Poesia Oral. UFMG, 2010.

Escritura e nomadismo. Ateliê Editorial. São Paulo, 2005.

WALKER ART CENTER. Life: Cuningham/Monk/Jones. AT\&T. New York. 1998.
ASCENSO SOARES, Flávia de Bastos; UHNG HUR, Dominico. O Corpo Encarcerado na obra de Antonin Artaud. Mnemosine Vol.13, nº1, p. 3-24 (2017)

ALMEIDA, Gil Roberto; LIGNELLI, César. No Marulhar das Glossolalias em Artaud. Rev. Bras. Estud. Presença, Porto Alegre, v. 6, n. 1, p. 71-93, jan./abr. 2016.

BONFITTO, Matteo. Entrevista com Erika Fischer Lichte. Conceição | Concept., Campinas, SP, v. 2, n. 1, p. 131-141, jan./jun. 2013.

FALBO, Conrado. As Notas sobre a voz, Meredith Monk. Revista Cena, n16. Periódico do Programa de Pós-graduação em Artes Cênicas. Universidade Federal do Rio Grande do Sul. 2014.

FERNANDES, José Fortunato. Método Dalcroze: perspectivas de aplicaçáo no canto coral. Revista Espaço Intermediário. São Paulo, 2010.

JIANG, Jack J. ZHANG, Yu, and MCGILLIGAN, Clancy. Chaos in Voice, From Modeling to Measurement. Wisconsin, 2005.

KAVASH, Deborah. An Introduction to Extended Vocal Techniques: Some Compositional Aspects and Performance Problems. Center for Music Experiment. DC San Diego. La Jolla. 1980.

MEIJER, Irene Costera \& PRINS, Baukje. Como os corpos se tornam matéria: entrevista com Judith Butler. Ponto de Vista. Estudos Feministas. 10. 1-2002.

MOREIRA, Virgínia. Da Máscara à Pessoa: a Construçáo Trágica de Homem. Rev. De Ciências Sociais, Fortaleza. V.XXV.N. 21-31.1994.

STOROLLI, Wânia. Meredith Monk: a arte nas fronteiras das linguagens. Urdimento, v.1, n.28, p. 78-87, julho 2017.

STOROLLI, Wânia. perVERSIONES: a voz performática de Fátima Miranda. Urdimento, v.1, n.22, p111-122, julho 2014 .

STOROLLI, Wânia. Performance: corpo e voz na prática musical. Comunicação. II Congresso da Associação Brasileira de Performance Musical. Vitória/ES. 2014.

TONELLI, Chriss. Social Virtuosity and the Improvising Voice; Phil Minton \& Maggie Nicols Interviewed by Chris Tonelli. Critical Studies in Improvisation / Études critiques en improvisation, Vol 10, No 2. 2016.

Ableism and the Reception of Improvised Sound-singing. 2016. https://quod.lib. umich.edu/m/mp/9460447.0010.204/--ableism-and-the-reception-of-improvised- soundsinging?rgn=main;view=fulltext 
VOVOLIS, Thanos; ZAMBOULAKIS, Giorgios. The Acoustical Mask of Greek Tragedy. Didaskalia. Volume 7 Issue 1, 2007.

VOVOLIS, Thanos. Máscaras Acústicas e Dimensões Sonoras do Teatro Grego Antigo, 2013.
Discografia

MONK, Meredith. Key (1971-1995) Lovely Music, Ltd. Produced by Collin Walcott.

Documentos do acervo especial de Meredith Monk na Biblioteca de Artes Performáticas da Biblioteca Pública de Nova York:

_ MONK, Meredith. Sarah Lawrence Commencement Speech. May 24, 1985.

_MONK, Meredith. SOME THOUGHTS ABOUT ART, AMERICA AND JUMPING OFF THE CLIFF. APRIL. 1990.

_MONK, Meredith. Vocal Journey. 1990

MONK, Meredith. Album Notes, Key. 


\section{Internet}

https://www.meredithmonk.org/ Acessado em maio de 2017.

LEAVER-YAP, Isla. The Voice is a Language. 2010. Disponível em: https://voiceisalanguage.wordpress.com/2010/04/19/text-meredith-monk-interviewed-by-isla-leaver-yap/ Acessado em abril de 2018

MONK, Meredith; HODGES Jim. BOMB. 2018. Disponível em: https://bombmagazine.org/articles/meredith-monk-and-jim-hodges/ Acessado em dezembro de 2018.

npr music. Meredith Monk On Q2’2 Spaces. 2014. Disponível em: http://www.npr.org/event/music/364682147/meredith-monk-on-q2s-spaces. Acessado em abril de 2016.

TATE. Meredith Monk - 'I Believe in the Healing Power of Art' | TateShots. 2017. Disponivel em: https://www.youtube.com/watch?v=R36Vh37-OQ4 Acessado em novembro de 2017.

DYLAN ROBINS, Sky. At Home with Meredith Monk. 2014. Disponível em https://www. newyorker.com/culture/culture-desk/home-meredith-monk. Acessado em setembro de 2017.

ROSS, Alex. Guided by Voices: Meredith Monk and Gabriel Kahane, at Bam. 2014. Disponível em: https://www.newyorker.com/magazine/2015/01/05/guided-voices. Acessado em setembro de 2017

MMONK HOUSE. Paris (1982) In partnership with KTCA, Meredith Monk \& Ping Chong's film adaptation of their theater piece from 1973. 2013. Disponível em: https://www.youtube.com/ watch?v=mKYauPXLnos. Acessado em janeiro de 2017.

WAKER ART CENTER. Walker Stage: Meredith Monk in Conversation with Philip Bither 2016. Disponível em https://www.youtube.com/watch?v=PamZUQ9k5uQ. Acessado em janeiro de 2017.

COLTER WALL, Seth. Meredith Monk, Key. 2017. Disponível em https://pitchfork.com/reviews/ albums/23186-keyl. Acessado em março de 2018.

"Meredith Monk's voice". On Being with Krista Tippett. Podcast online, 2012a. Disponível em: http://www.onbeing.org/program/meredith-monks-voice/1398.

Acessado em novembro de 2017.

STAMPS, School of Art and Design. Interview with Meredith Monk. 2017. Disponível em: https:// www.youtube.com/watch?v=qg7iUvllpHY Acessado em abril de 2018.

https://conversations.e-flux.com/t/yvonne-rainer-no-manifesto/1454 Acessado em abril de 2018.

LEAVER-YAP, Isla. Meredith Monk: Perception as Content. 2010. Disponível em: https://www. afterall.org/online/meredith.monkperception.as.content\#.Wt3Ff4jwbIU Acessado em abril de 2018 NEW YORK PUBLIC RADIO, Q2 MUSIC. Mind-Blowing, Mystical 24-Hour Meredith Monk Marathon. 2016. Disponível em:-https://www.wqxr.org/story/meredith-monks-magical-mystical-marathon/
Acessado em maio de 2018.

TERRA, Inés. Alguma coisa sobre voz. NME. 2017. Disponível em http://linda.nmelindo. com/2017/07/alguma-coisa-sobre-voz/ Acessado em maio de 2018.

JOY, Jenn. Okwui Okpokwasili. BOMB. 2016. Disponível em: https://bombmagazine.org/articles/ okwui-okpokwasili/ Acessado em novembro de 2018.

MOVEMENT RESEARCH. Okwui Okpokwasili in Conversation with Tess Dworman. 2017. Disponível em: https://movementresearch.org/publications/critical-correspondence/okwui-okpokwasili-in-conversation-with-tess-dworman Acessado em agosto de 2018.

LENTJES, Rebeca. Voices, voices in space, and spaces: Thoughts on 50 years of Meredith Monk. 2015. Disponivel em: https://www.icareifyoulisten.com/2015/04/thoughts-on-50-years-of-meredithmonk/ Acessado em março de 2019.

WOOLFE, Zachary. A Singular World That Won't Fade Away. The New York Times. 2014. Disponível em: https://www.nytimes.com/2014/11/30/arts/music/meredith-monk-celebrates-50-years-of-work.html

Acessado em março de 2019.

At Home with Meredith Monk -Annals of Sound. The New Yorker. 2014. Disponível em: https:// www.youtube.com/watch?v=11e-MkRFXuc Acessado em março de 2019.

NEW SOUNDS. Live In Studio: Meredith Monk. 2018. Disponível em: https://www.youtube. com/watch?v=lee3TFChZyY\&t=885s Acessado em novembro de 2018.

SCHMELZER, Paul. Repeat Cycles: Meredith Monk on Voice, \#MeToo, and Recurring History. Walker Art. Disponível em: https://walkerart.org/magazine/meredith-monk-on-voice-metoo-and-recurring-history

Acessado em março de 2019

MONALISA GHARAVI, Maryam. In the Studio: Meredith Monk. 2017. Disponível em: https:// www.artinamericamagazine.com/news-features/magazines/in-the-studio-meredith-monk/

Acessado em junho de 2019. 
148 